Supporting information

Diverse Mechanistic Pathways in Single-Site Heterogeneous Catalysis. Alcohol Conversions Mediated by a High-Valent Carbon-Supported Molybdenum-Dioxo Catalyst

Jiaqi Li, ${ }^{1,3}$ Anusheela Das, ${ }^{2,3}$ Qing Ma, ${ }^{2}$ Michael J. Bedzyk, ${ }^{2,3}$ Yosi Kratish, ${ }^{\star 1,3}$ Tobin J. Marks ${ }^{\star 1,3}$

${ }^{1}$ Department of Chemistry, Northwestern University, Evanston, Illinois 60208, United States.

${ }^{2}$ Department of Materials Science and Engineering, Northwestern University, Evanston, Illinois 60208, United States.

${ }^{3}$ The Institute for Catalysis in Energy Processes (ICEP), Northwestern University, Evanston, Illinois 60208, United States.

`Email: yosi.kratish@northwestern.edu; t-marks@northwestern.edu

Table of Contents 


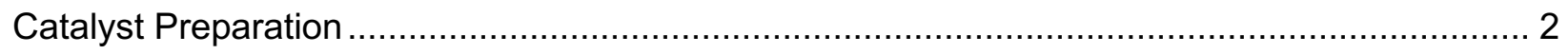

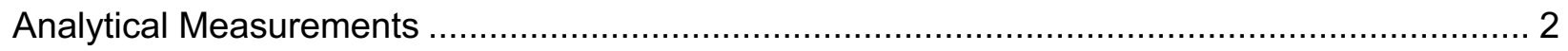

Dehydration and Dehydrogenation Procedure ………….............................................. 2

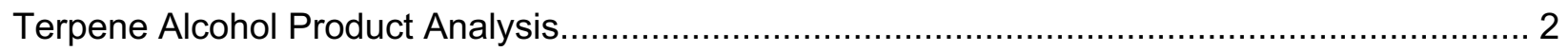

Comparison of Linalool Dehydration Product Selectivity ....................................................... 4

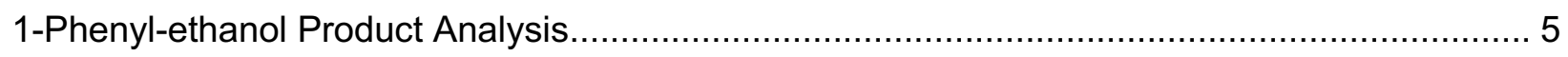

1-Octanol Dehydrogenation Products Analysis ……............................................................. 6

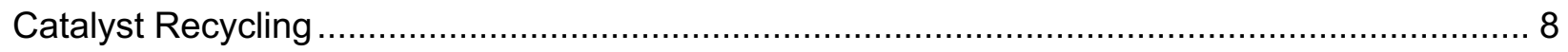

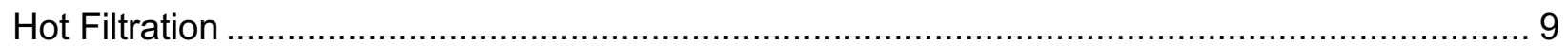

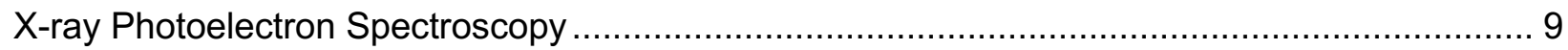

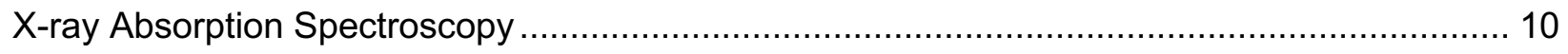

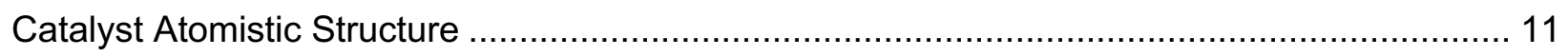

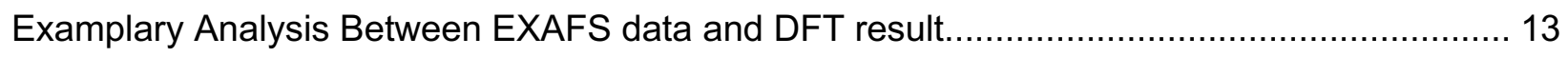

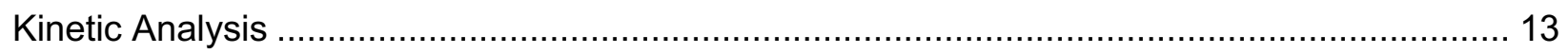

Determination of [3-ethyl-3-pentanol] reaction order .................................................... 14

Determination of $\left[\mathrm{AC} / \mathrm{MoO}_{2}\right]$ order ............................................................................. 14

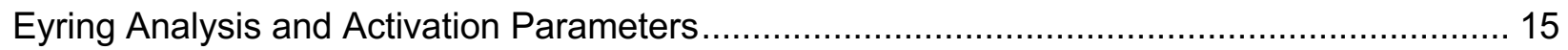

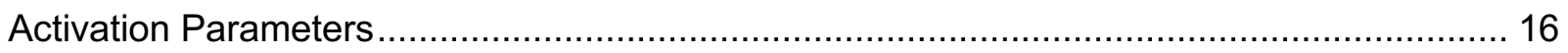

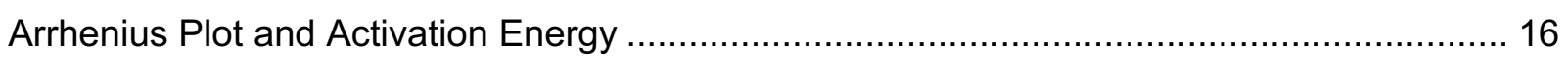

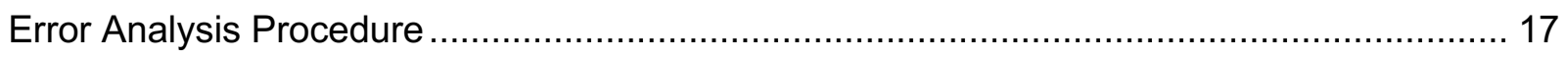

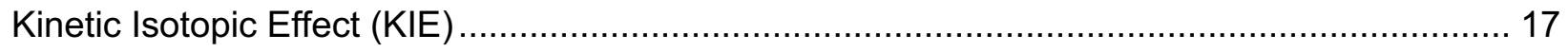

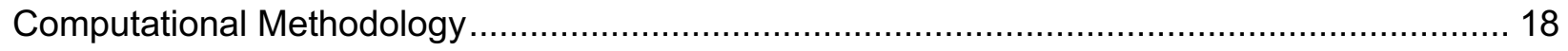

Computational Details for Non-Water-Assisted Pathway ........................................................ 19

Computational Details for Water-Assisted Pathway ........................................................... 19

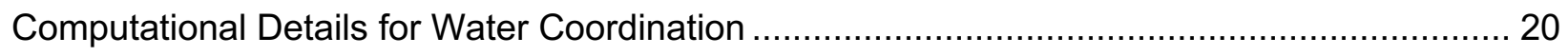

Computational Details for Proton Transfer To Terminal Oxygen............................................. 20

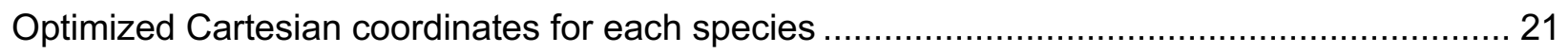

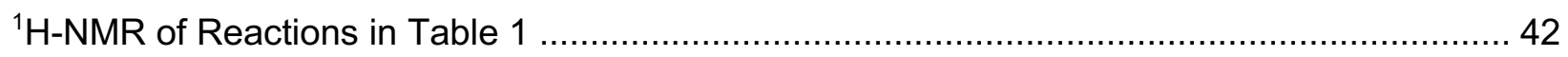

Spectroscopic Data for Dehydrated/Dehydrogenated Products and References. ..................... 49

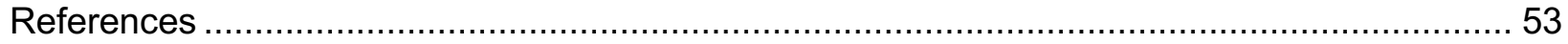

\section{General Considerations}

Activated carbon (06-0100, Lot\#2562087) was purchased from Strem Chemicals. The reagents cyclooctanol and linalool were purchased from TCl America. Terpinen-4-ol was purchased from 
Acros Oganics. The substrates 1-phenyl-1-propanol and 1-octadecanol were purchased from Alfa Aesar. All other starting materials and solvents were purchased from Sigma-Aldrich. Mesitylene, xylene, and decalin were stored over dehydrated molecular sieves. All other chemicals were used without further purification unless otherwise noted.

\section{Catalyst Preparation}

Detailed catalyst preparation procedures are provided as described previously. ${ }^{1}$ In brief, a Schlenk flask was charged with solid (dme) $\mathrm{MoO}_{2} \mathrm{Cl}_{2}$ in a glove box. Then, the flask was removed from the glovebox and attached to a Schlenk line. Under $\mathrm{N}_{2}$ atmosphere, $15 \mathrm{~mL}$ anhydrous dichloromethane was added to the flask forming a colorless solution. Under $\mathrm{N}_{2}$ atmosphere, 15 $\mathrm{mL}$ anhydrous dichloromethane was added to another flask containing $5.0 \mathrm{~g}$ of pre-dried activated carbon. Then the $\mathrm{MoO}_{2} \mathrm{Cl}_{2}$ (dme) solution was cannulated into the second flask with the activated carbon suspension. The resulting suspension was stirred gently for $18 \mathrm{~h}$ at room temperature. The supernatant DCM solution was cannula filtered off and the filtrate washed $2 x$ more with anhydrous DCM. The catalyst was then re-suspended in DCM, vacuum filtered under ambient conditions, and further dried in vacuo overnight.

\section{Analytical Measurements}

${ }^{1} \mathrm{H}$ and ${ }^{13} \mathrm{C}$ NMR spectra were recorded at Integrated Molecular Structure Education and Research Center (IMSERC) at Northwestern University with a $500 \mathrm{MHz}$ Bruker Avance III HD system equipped with a TXO Prodigy probe. Chemical shifts $(\delta)$ for ${ }^{1} \mathrm{H}$ and ${ }^{13} \mathrm{C}$ are referenced to TMS. Mesitylene was used as an internal standard. GC/MS analyses were recorded at IMSERC at Northwestern University with an Agilent 7890 GC-TOF equipped with a 30 meter DB-5 column. An initial temperature of $75^{\circ} \mathrm{C}$ was held for 2 min before applying a ramp rate of $20 \mathrm{C} / \mathrm{min}$ up to $300 \mathrm{C}^{\circ}$, then held at $300{ }^{\circ} \mathrm{C}$ for an additional $1 \mathrm{~min}$. ICP analysis of the catalyst Mo metal loading was performed by Galbraith Labs (Knoxville, TN).

\section{Dehydration and Dehydrogenation Procedure}

In a typical experiment, the alcohol substrate $(1 \mathrm{mmol})$, mesitylene $(0.07 \mathrm{~mL}, 0.5 \mathrm{mmol})$, decalin $(1.0 \mathrm{~mL}), \mathrm{AC} / \mathrm{MoO}_{2}(1 \mathrm{~mol} \% \mathrm{Mo} ; 25 \mathrm{mg}$ of $3.82 \mathrm{wt} \%$ Mo catalyst), and a PTFE coated magnetic stir bar were added to a $25 \mathrm{~mL} \mathrm{~J}$-Young reaction flask in air. The solution was degassed, then placed under Ar, and kept sealed throughout the reaction. While stirring at $400 \mathrm{rpm}$, the flask was lowered into an oil bath (for temperatures below $150{ }^{\circ} \mathrm{C}$ ) or an aluminum block heater (for temperatures above $150{ }^{\circ} \mathrm{C}$ ) at the desired temperature behind a blast shield. Samples were periodically withdrawn and analyzed via NMR spectroscopy to monitor the course of the reaction. Conversion and selectivity were calculated by ${ }^{1} \mathrm{H}$-NMR spectroscopy by integration against the mesitylene internal standard. All reported products are known compounds and were compared to published ${ }^{1} \mathrm{H} /{ }^{13} \mathrm{C}$ NMR values when possible and verified by $\mathrm{GC} / \mathrm{MS}$ when appropriate.

\section{Terpene Alcohol Product Analysis}

Table S1. $\mathrm{AC} / \mathrm{MoO}_{2}$ catalyzed terpene alcohol conversion ${ }^{\text {a }}$

\begin{tabular}{llll}
\hline Entry & Time & Conv. & Yield (Product) \\
\hline 1 & &
\end{tabular}




$\begin{array}{rrrr}1 \mathrm{~h} & 57 \% & 23 \%(\mathbf{1}), 8 \%(2), 18 \%(3), 6 \%(4) \\ 7 \mathrm{~h} & 91 \% & 32 \%(1), 18 \%(2), 22 \%(3), 14 \%(4)\end{array}$

\begin{abstract}
${ }^{a}$ Conditions unless specified otherwise: $1.0 \mathrm{mmol}$ substrate, $1 \mathrm{~mol} \%$ Mo $(25 \mathrm{mg}$ of $3.82 \mathrm{wt} \%$ $\mathrm{AC} / \mathrm{MoO}_{2}$ ), $1.0 \mathrm{mmol}$ mesitylene (internal standard), $1.0 \mathrm{~mL} \mathrm{p}$-xylene (solvent), $400 \mathrm{rpm}, 100{ }^{\circ} \mathrm{C}$, under Ar. Conversions and yields were determined by ${ }^{1} \mathrm{H}-\mathrm{NMR}$ spectroscopy using mesitylene as internal standard; products are confirmed by ${ }^{13} \mathrm{C}-\mathrm{NMR}$ and GC/MS.
\end{abstract}
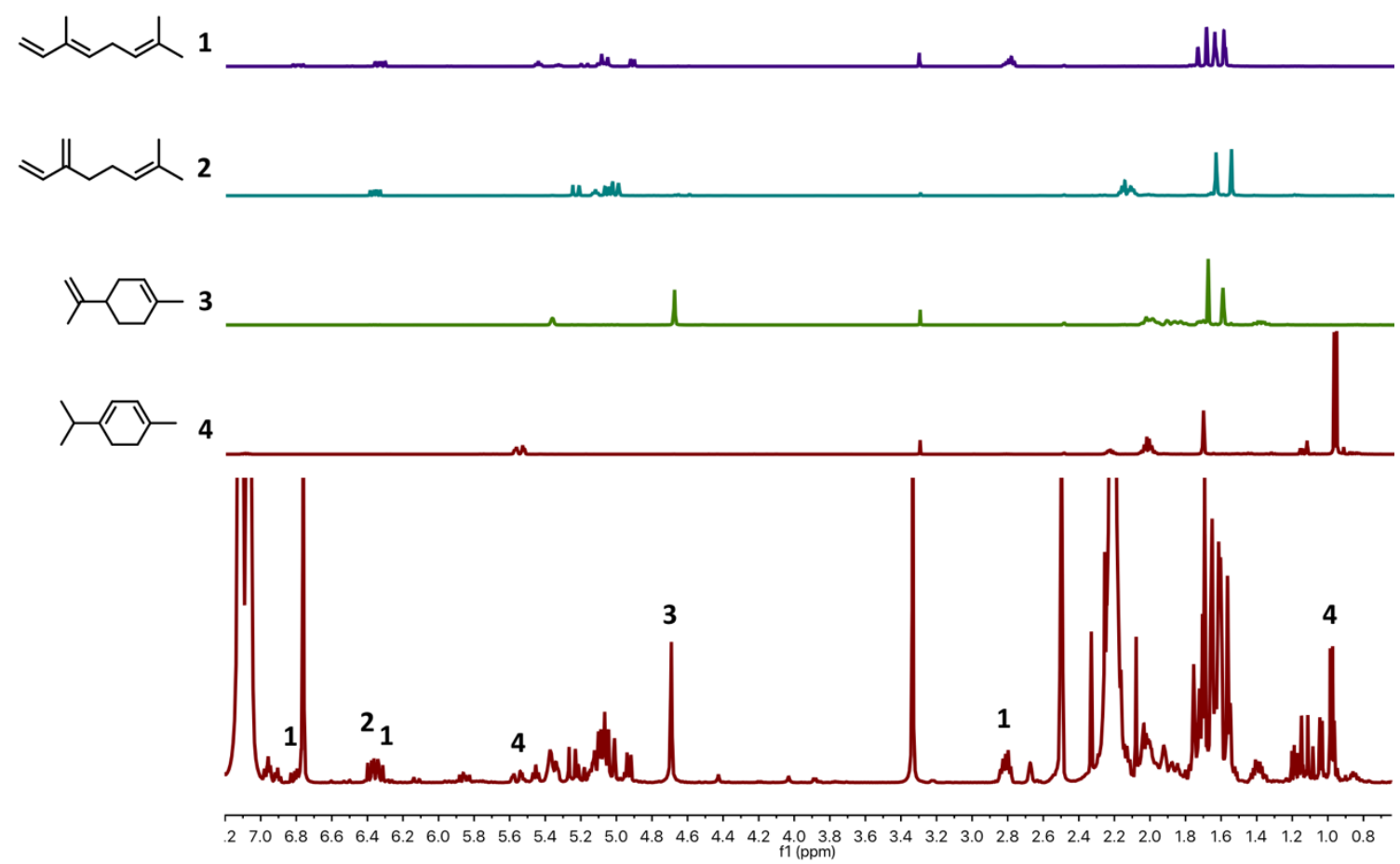

Figure S1. $\delta$ 7.20-0.64 ppm of H-NMR spectra of linalool dehydration and standard products. 


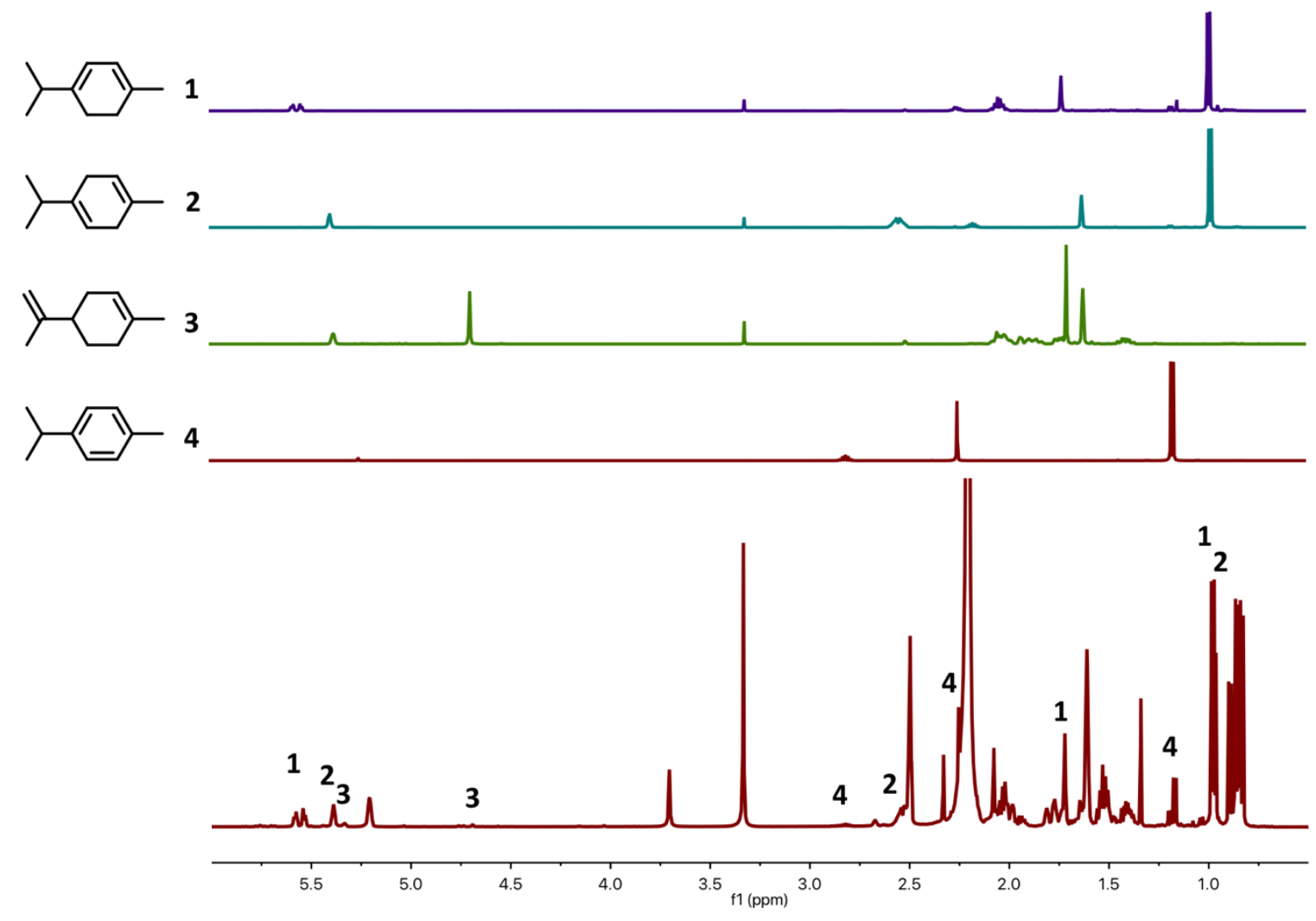

Figure S2. $\delta$ 6.00-0.50 ppm of H-NMR spectra of terpinen-4-ol dehydration and standard products.

\section{Comparison of Linalool Dehydration Product Selectivity}

$\mathrm{H}_{2} \mathrm{SO}_{4}$ and $\mathrm{Re}_{2} \mathrm{O}_{7}$ have been reported for catalyzing alcohol dehydration. ${ }^{2}$ Table S2 summarizes the product selectivity of $\mathrm{H}_{2} \mathrm{SO}_{4}, \mathrm{Re}_{2} \mathrm{O}_{7}$, and $\mathrm{AC} / \mathrm{MoO}_{2}$ catalyzed linalool dehydration. It can be seen that $\mathrm{AC} / \mathrm{MoO}_{2}$ has different product selectivity than $\mathrm{H}_{2} \mathrm{SO}_{4}$. For example, negligible amounts of $\gamma$-terpene and p-cymene were detected from the $\mathrm{AC} / \mathrm{MoO}_{2}$ system, while these two products account for more than $50 \%$ in the $\mathrm{H}_{2} \mathrm{SO} 4$ system. The $\mathrm{AC} / \mathrm{MoO}_{2}$ selectivity for ocimene is closer to that of the $\mathrm{Re}_{2} \mathrm{O}_{7}$ system than the $\mathrm{H}_{2} \mathrm{SO}_{4}$ system. The selectivity pattern indicates $\mathrm{AC} / \mathrm{MoO}_{2}$ catalyzes alcohol dehydration through a different pathway than $\mathrm{H}_{2} \mathrm{SO}_{4}$.

Table S2. Linalool dehydration product selectivity

\begin{tabular}{lllllll}
\hline Catalyst & \multicolumn{6}{l}{ Selectivity } \\
\cline { 2 - 7 } & Ocimene & myrene & limonene & $\begin{array}{l}\alpha \text { - } \\
\text { terpene }\end{array}$ & $\begin{array}{l}\theta \text { - } \\
\text { terpene }\end{array}$ & $\begin{array}{l}\text { Others }(\gamma \text {-terpene, } \mathrm{p} \text { - } \\
\text { cymene })\end{array}$ \\
\cline { 2 - 7 }${\mathrm{AC} / \mathrm{MoO}_{2}{ }^{\mathrm{a}}}$ & $35 \%$ & $20 \%$ & $24 \%$ & $15 \%$ & - & - \\
$\mathrm{Re}_{2} \mathrm{O}_{7}{ }^{\mathrm{b}}$ & $32 \%$ & - & $43 \%$ & - & $22 \%$ & $2 \%$ \\
$\mathrm{H}_{2} \mathrm{SO}_{4}{ }^{\mathrm{b}}$ & $11 \%$ & - & $20 \%$ & - & $25 \%$ & $56 \%$ \\
\hline
\end{tabular}


a. $1.0 \mathrm{mmol}$ substrate, $1 \mathrm{~mol} \% \mathrm{Mo}\left(25 \mathrm{mg}\right.$ of $3.82 \mathrm{wt} \% \mathrm{AC} / \mathrm{MoO}_{2}$ ), $1.0 \mathrm{mmol}$ mesitylene (internal 1H-NMR standard), $1.0 \mathrm{~mL}$ solvent, $400 \mathrm{rpm}$ stirring under $\mathrm{Ar}$

b. $2 \mathrm{mmol}$ of substrate, $0.01 \mathrm{mmol}$ of $\mathrm{Re}_{2} \mathrm{O}_{7}$ or $0.05 \mathrm{mmol}$ of $\mathrm{H}_{2} \mathrm{SO}_{4}, 250 \mu \mathrm{L}$ of pentadecane (IS), $10 \mathrm{~mL}$ of toluene, air, magnetic stirring, $100{ }^{\circ} \mathrm{C}^{2}$

\section{1-Phenyl-ethanol Product Analysis}

The general procedure was used for 1-phenyl-ethanol conversion. The reaction was periodically cooled to room temperature and analyzed via NMR spectroscopy to monitor the products and the course of the reaction $(0,1 \mathrm{~h}, 2 \mathrm{~h}, 3 \mathrm{~h})$. At time zero, only the substrate $(\delta 4.93 \mathrm{ppm})$, solvent, and internal standard peaks are observed. As the reaction proceeds, 1-phenyl-ethanol peaks decrease and product peaks appear. By comparing to the literature, peaks at $\delta 6.73 \mathrm{ppm}, 5.79$ ppm, and $5.28 \mathrm{ppm}$ are assigned to styrene (Figure S3, 1); $\delta 7.98 \mathrm{ppm}, 2.58 \mathrm{ppm}$ to acetophenone (Figure S3, 2) ${ }^{4} \delta 4.57 \mathrm{ppm}, 4.28 \mathrm{ppm}$ to bis(alpha-phenylethyl) ether (Figure S3, $3) ;{ }^{5} \delta 3.69 \mathrm{ppm}$ to the coupling product (Figure S3,4). ${ }^{6}$ The direct coupling of alcohols with olefins forming the coupling product (longer chain olefins) is a known reaction and can be catalyzed by several catalysts, such as Mo/zeolite, ${ }^{7} \mathrm{~W}$-heteropolyacids, ${ }^{8}$ and $\mathrm{Pd} .{ }^{9}$

During the course of the reaction, the ether peaks gradually decrease, which indicates that ether goes through a second step and is converted to other products. Alkene formation from decomposition of ether is known and the elimination mechanism have been calculated as a favorable pathway when catalyzed by alumina. ${ }^{10}$ Meanwhile, looking at the yield sum of products 1-4 (Table S2, sum of 1-4), an increasing amount of imbalance can be observed (Table S2, yield sum / conversion). This is likely due to styrene polymerization, as many catalysts have shown activity for this transformation, including $\mathrm{MoO}_{\mathrm{x}} /$ silica-alumina. ${ }^{11,12}$

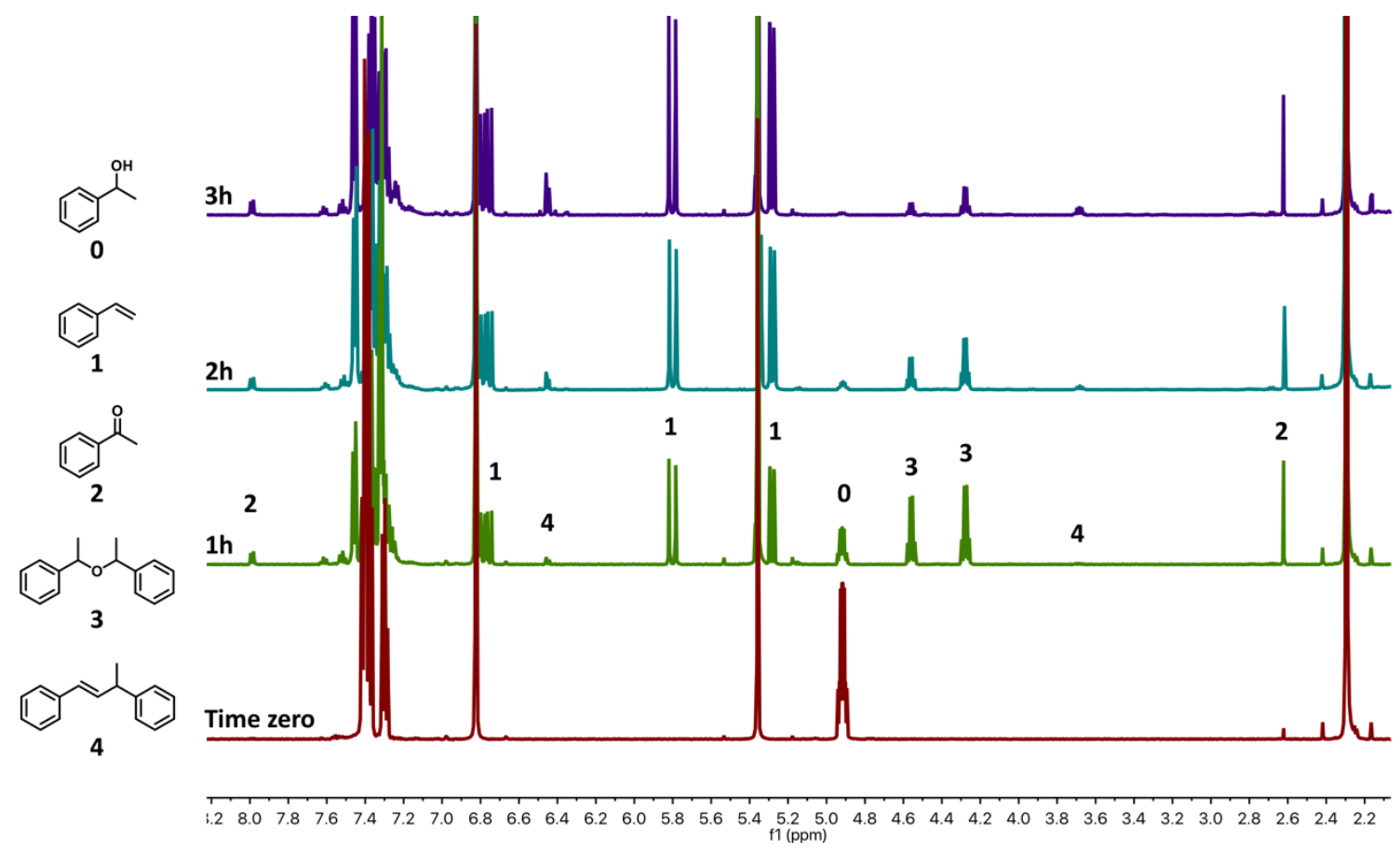

Figure S3. $\delta$ 8.2-2.1 ppm of H-NMR spectra at different time points during 1-phenyl-ethanol conversion. 
Table S3. 1-phenyl-ethanol product mass balance analysis

\begin{tabular}{|c|c|c|c|c|c|c|c|}
\hline \multirow[b]{2}{*}{ time } & \multirow[b]{2}{*}{ conversion } & \multicolumn{5}{|c|}{ yield (product) } & \multirow[b]{2}{*}{ yield sum/conversion } \\
\hline & & 1 & 2 & 3 & 4 & sum of $1-4$ & \\
\hline $1 \mathrm{~h}$ & $73 \%$ & $30 \%$ & $2 \%$ & $26 \%$ & $6 \%$ & $64 \%$ & $88 \%$ \\
\hline $2 \mathrm{~h}$ & $94 \%$ & $55 \%$ & $3 \%$ & $18 \%$ & $3 \%$ & $79 \%$ & $84 \%$ \\
\hline $3 \mathrm{~h}$ & $97 \%$ & $59 \%$ & $3 \%$ & $7 \%$ & $5 \%$ & $74 \%$ & $76 \%$ \\
\hline
\end{tabular}

\section{1-Octanol Dehydrogenation Products Analysis}

\section{Experiment}

1-octanol $(0.08 \mathrm{~mL}, 0.5 \mathrm{mmol})$, mesitylene $(0.04 \mathrm{~mL}, 0.3 \mathrm{mmol})$, decalin- $\mathrm{d}_{10}(0.5 \mathrm{~mL})$, and $\mathrm{AC} / \mathrm{MoO}_{2}$ (1 mol\% Mo, $12.5 \mathrm{mg}$ of $3.82 \mathrm{wt} \%$ ) were added to a high-pressure J-Young NMR-tube in air. The solution was degassed, placed under Ar, then lowered into an aluminum block at 250 ${ }^{\circ} \mathrm{C}$. The reaction was periodically cooled down and analyzed via NMR spectroscopy to monitor the products and the course of the reaction $(0,2 \mathrm{~h}, 4 \mathrm{~h}, 6 \mathrm{~h}, 8 \mathrm{~h}, 20 \mathrm{~h})$.

\section{Interpretation}

At time zero, ${ }^{1} \mathrm{H}-\mathrm{NMR}$ spectra were acquired, and only 1-octanol and mesitylene (internal standard) peaks were observed (compounds 0 and 4 in Figure S4). During the course of the reaction, 1-octanol peaks decrease, and several peaks in the region for aldehyde, olefin, ether, and ester appear. By comparing to the literature, the peak at $\delta 198 \mathrm{ppm}$ is assigned to octanal. Peaks at $\delta 147$ ppm, 145 ppm, and 114 ppm are assigned to a mix of octenes (1-octene, 2-octene, trans-4-octene, etc.), as a result of dehydration and isomerization. ${ }^{13-18}$ Peaks in the region of $\delta$ 100 ppm - 95 ppm are attributed to acetal fragments (structure shown in Scheme S1 a) and $\delta 70$ $-63 \mathrm{ppm}$ are attributed to ether fragments (structure shown in Scheme S1 b). ${ }^{19-21}$

No observable alcohol consumption was detected when replacing the AC/MoO2 with activated carbon and repeating the same reaction. These indicate that 1) 1-octanol does not significantly react with the carbon surface functional groups; 2) instead it undergoes different pathways, including dehydration and dehydrogenation; 3) and the dehydrogenated aldehyde goes through multiple pathways, generating a mix of final products, including the assigned products and others. For 1-octanol, comparing the appearance order of the various ${ }^{1} \mathrm{H}-\mathrm{NMR}$ peaks, characteristic ester signals ( $\delta 174$ and 64 ppm) appear later than aldehyde, suggesting 1octanol likely proceeds through similar intermediates formed by nucleophilic attack by the alcohol on an intermediate aldehyde. Therefore, it is reasonable to propose the occurrence of, and assign the peaks to octyl octanoate and other octanoates.

The conversion of an alcohol to an acetal is a known reaction and can be catalyzed by several homogeneous Ru complexes. ${ }^{22}$ Moreover, alcohol dehydrogenative esterification is a known transformation and can be catalyzed by several homogeneous transition metal catalysts, such as $\mathrm{Ru}$ complexes and Os complexes, as well as heterogeneous $\mathrm{Cu} / \mathrm{ZrO}_{2}$ and $\mathrm{MoS}_{2 .}{ }^{23-25}$ In typical reaction pathways, the alcohol is first dehydrogenated to the corresponding aldehyde, next the aldehyde product condenses with alcohol generating hemiacetal, and lastly the hemiacetal is dehydrogenated to the corresponding ester. ${ }^{23}$ In the case of $\mathrm{AC} / \mathrm{MoO}_{2}$, aldehyde oligomerization is believed to be the driving force for low-temperature ethanol dehydrogenation in the previously proposed pathway. ${ }^{26}$ Furthermore, aldehyde cyclotrimerization is known ${ }^{22,}{ }^{24}$ and generally catalyzed by acids, including protonic acids, Lewis acids, and Keggin-type hetero-polyacids, such 
as $\mathrm{H}_{3} \mathrm{PM}_{12} \mathrm{O}_{40}(\mathrm{M}=\mathrm{Mo}, \mathrm{W}){ }^{61,62}$ In all cases, ethers and acetals will be generated, thus it is reasonable to expect di-octyl ether, tri-octyl ether, ether oligomers of different length, and others to be the intermediates and the products. Moreover, the corresponding peaks are observed in $\mathrm{H}$ NMR and GC/MS. One possible peak assignment is shown in Figure S4 and S5, and a possible transformation map is shown in Scheme S2.

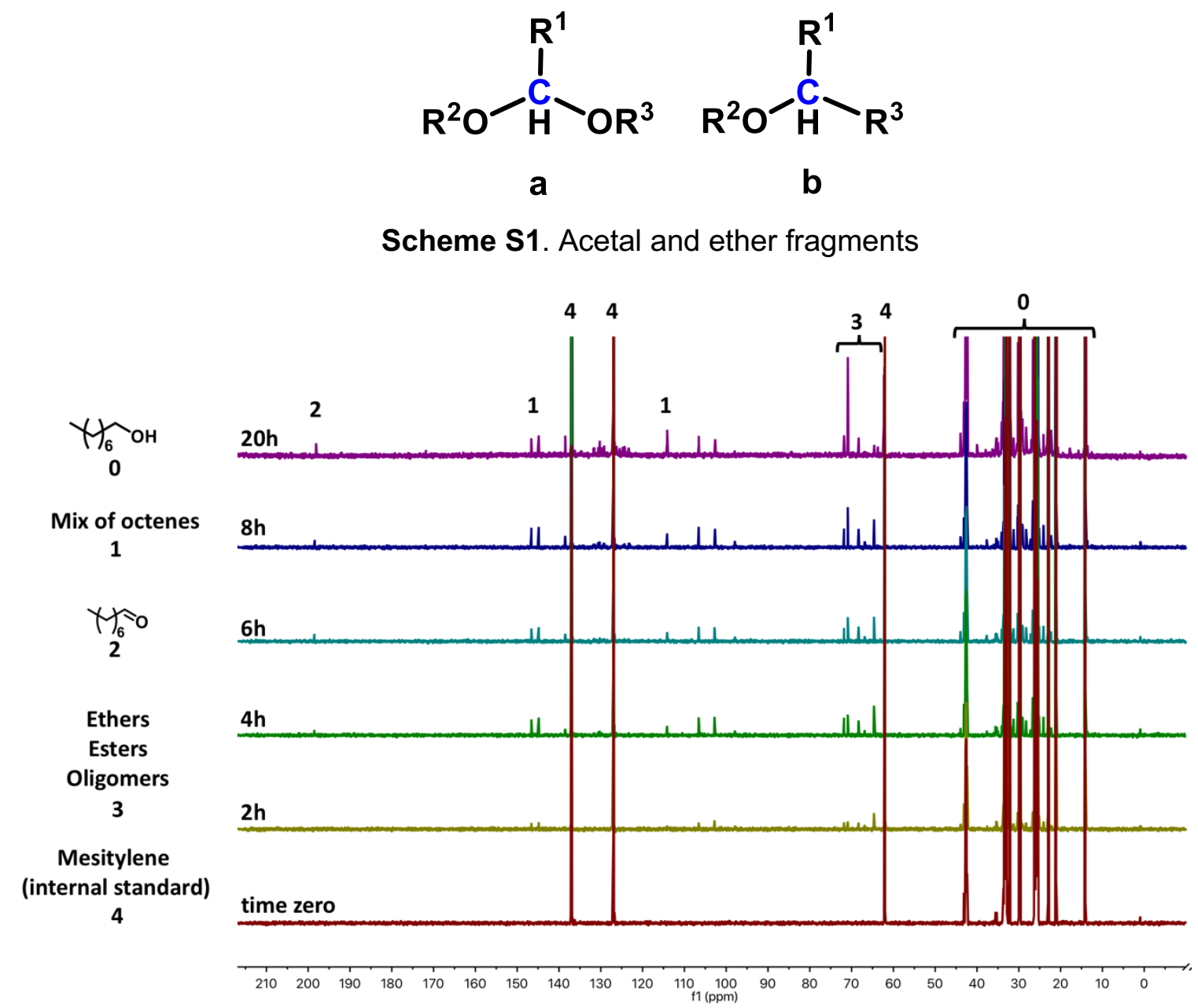

Figure S4. $\delta \quad 0.0-220$ ppm region of the ${ }^{13} \mathrm{C}-\mathrm{NMR}$ spectra at different time points during 1octanol conversion. 


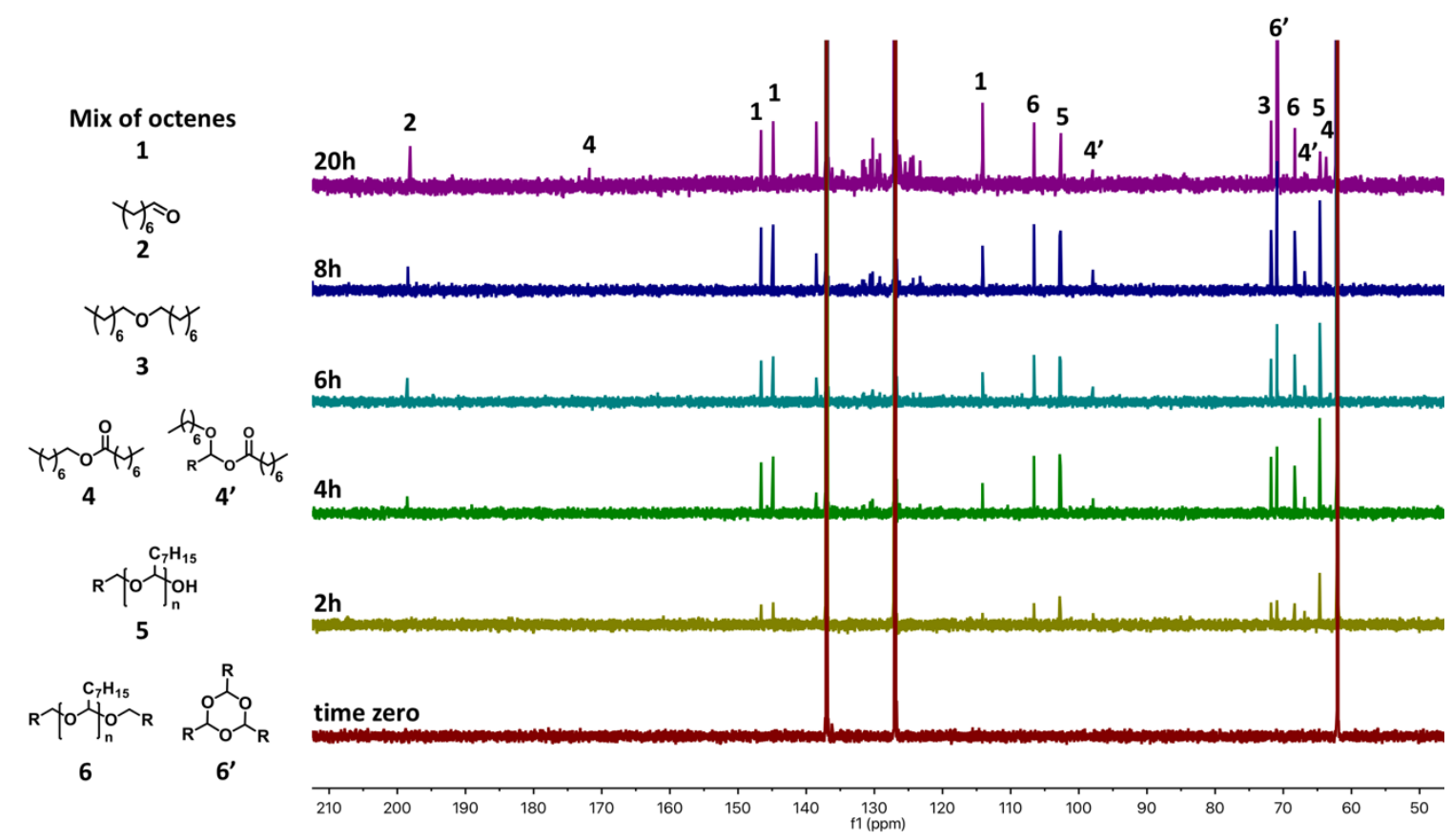

Figure S5. $\delta 50-210 \mathrm{ppm}$ of the ${ }^{13} \mathrm{C}-\mathrm{NMR}$ spectra at different time points during 1-octanol conversion.

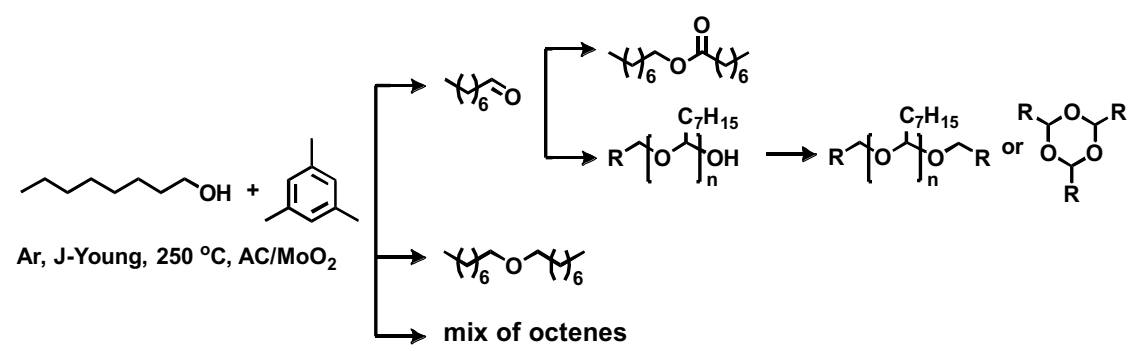

Scheme S2. Products and proposed pathway of 1-octanol conversion

\section{Catalyst Recycling}

The catalyst was recycled and reused a total of 5 times, with the exact amount of catalyst and substrate used listed in Table S4. Each time, 2-phenyl-2-propanol (x mmol), mesitylene (0.5x $\mathrm{mmol})$, o-xylene $(\mathrm{x} \mathrm{mL}), \mathrm{AC} / \mathrm{MoO}_{2}(1 \mathrm{~mol} \% \mathrm{Mo})$, and a PTFE coated magnetic stir bar were added to a $25 \mathrm{~mL}$ J-Young flask in air. The solution was degassed, placed under Ar, sealed, heated to $110{ }^{\circ} \mathrm{C}$ for $40 \mathrm{~min}$. Samples were collected and measured via NMR. Then the mixture was filtered using a Buchner funnel and the $\mathrm{AC} / \mathrm{MoO}_{2}$ catalyst was collected and washed using ethanol $(3 \mathrm{x}$ $1 \mathrm{~mL})$ and acetone $(3 \times 1 \mathrm{~mL})$. The catalyst was then allowed to air dry.

Table S4 Amount of Recycled Catalyst and Substrate

\begin{tabular}{llllll}
\hline Time & $\mathrm{AC}_{\mathrm{MoO}}$ & 2-phenyl-2-propanol & mesitylene & o-xylene & Conv. (40 min) \\
\hline 1 & $50 \mathrm{mg}$ & $0.37 \mathrm{~g}$ & $0.14 \mathrm{~mL}$ & $2.0 \mathrm{~mL}$ & $19 \%$
\end{tabular}




\begin{tabular}{llllll}
2 & $43 \mathrm{mg}$ & $0.32 \mathrm{~g}$ & $0.12 \mathrm{~mL}$ & $1.7 \mathrm{~mL}$ & $15 \%$ \\
3 & $35 \mathrm{mg}$ & $0.26 \mathrm{~g}$ & $0.10 \mathrm{~mL}$ & $1.4 \mathrm{~mL}$ & $20 \%$ \\
4 & $21 \mathrm{mg}$ & $0.16 \mathrm{~g}$ & $0.06 \mathrm{~mL}$ & $0.8 \mathrm{~mL}$ & $18 \%$ \\
5 & $16 \mathrm{mg}$ & $0.11 \mathrm{~g}$ & $0.05 \mathrm{~mL}$ & $0.6 \mathrm{~mL}$ & $20 \%$ \\
\hline
\end{tabular}

\section{Hot Filtration}

2-phenyl-2-propanol (0.137 g, $1.0 \mathrm{mmol})$, mesitylene $(0.07 \mathrm{~mL}, 0.5 \mathrm{mmol})$, o-xylene $(1.0 \mathrm{~mL})$, $\mathrm{AC} / \mathrm{MoO}_{2}(1 \mathrm{~mol} \% \mathrm{Mo}, 25 \mathrm{mg}$ of $3.82 \mathrm{wt} \%$ ), and a PTFE coated magnetic stir bar were added to a $25 \mathrm{~mL} \mathrm{J-Young} \mathrm{flask} \mathrm{in} \mathrm{air.} \mathrm{The} \mathrm{solution} \mathrm{was} \mathrm{degassed,} \mathrm{placed} \mathrm{under} \mathrm{Ar,} \mathrm{heated} \mathrm{to} 100{ }^{\circ} \mathrm{C}$ for $15 \mathrm{~min}$, then canula filtered to another degassed and Ar backfilled flask. The filtrate was heated to $100{ }^{\circ} \mathrm{C}$ for $15 \mathrm{~min}$ under $\mathrm{Ar}$ and samples from both flasks were collected and measured via NMR. The filtrate remains colorless and no further by conversion the filtrate was observed.

\section{X-ray Photoelectron Spectroscopy}

XPS spectra were collected at the Keck II facility at Northwestern University with a Thermo Scientific ESCALAB 250Xi spectrometer, equipped with an Al $\mathrm{K}$ alpha radiation source and electron flood-gun, at a pressure of $8 \times 10^{-8}$ mbar with a pass energy of $50 \mathrm{eV}$. Binding energies were referenced against that of adventitious carbon, which was set at $284.4 \mathrm{eV}$. Typically, a 500 ms dwell time and 10-20 scans were used for each spectrum. The comparison Mo $3 \mathrm{~d}$ spectra were normalized using Origin. The survey scan and the Mo and oxygen spectra of the fresh and the spent catalyst are shown below.
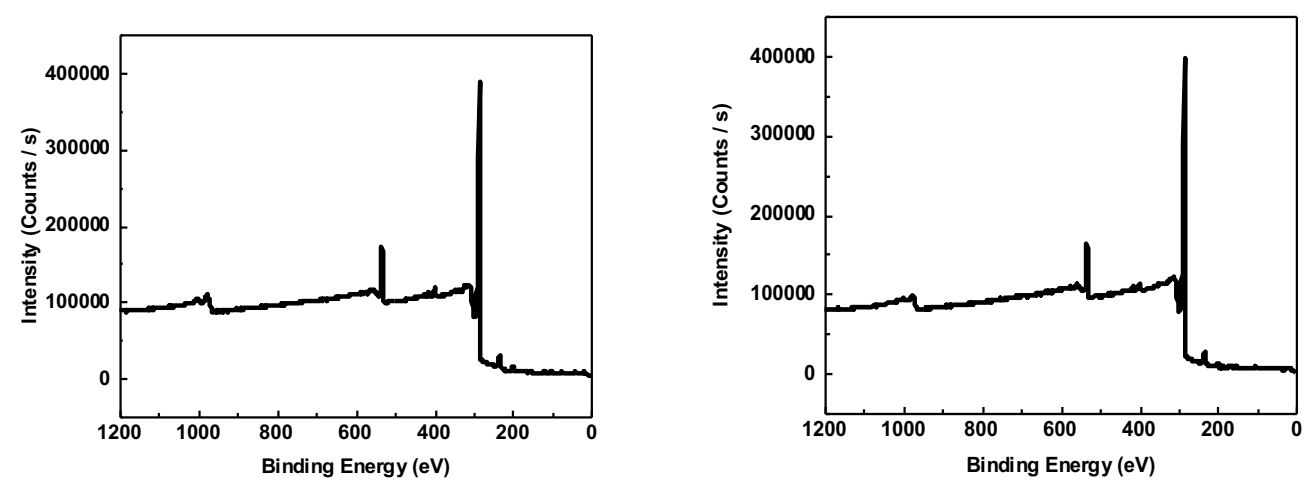

Figure S6. XPS survey scan of fresh (left) and spent (right) $\mathrm{AC} / \mathrm{MoO}_{2}$ 

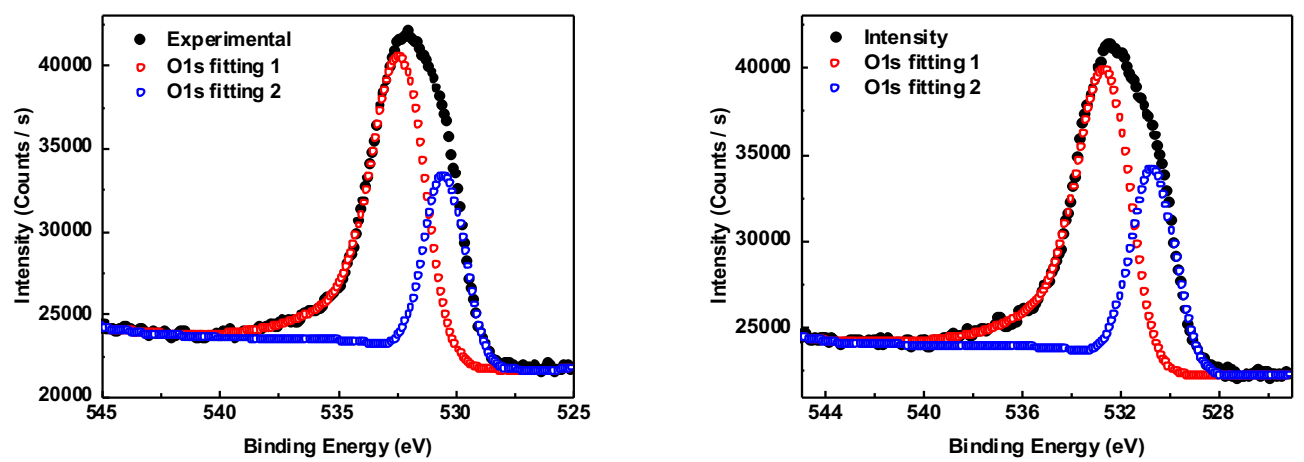

Figure S7. XPS O(1s) spectra of fresh(left) and spent (right) $\mathrm{AC} / \mathrm{MoO}_{2}$ showing fittings
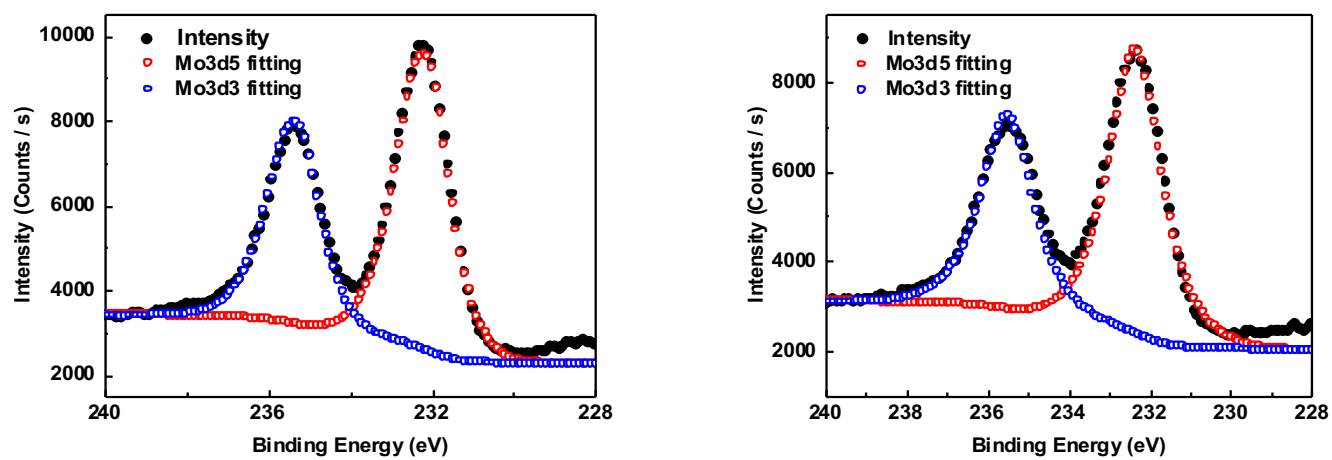

Figure S8. XPS Mo(3d) spectrum of fresh (left) and used (right) $A C / M o O_{2}$ showing fittings

\section{X-ray Absorption Spectroscopy}

X-ray absorption near edge structure (XANES) and extended X-ray absorption fine structure (EXAFS) measurements were conducted at the 5 BM-D beamline of the DND-CAT at the Advanced Photon Source. Measurements were performed at Mo K-edge (20.00 keV). For energy selection, a double $\mathrm{Si}$ (111) monochromator was used which has a resolution of $\Delta \mathrm{E} / \mathrm{E}=1.4 \times 10$ 4. The X-ray energy was referenced to a metallic Mo foil (EXAFS Materials) whose spectrum was collected simultaneously for each energy scan. The incident X-ray intensity was measured in an ionization chamber (FMB-Oxford) filled with 600 Torr He/100 Torr $\mathrm{N}_{2}$ and was detuned to $60 \%$ of its maximum intensity for harmonic rejection. The Mo foil was measured using an ionization chamber filled with 760 Torr Ar. The powder catalyst $\mathrm{AC} / \mathrm{MoO}_{2}$ with a loading of $2 \mathrm{wt} \%$ were pressed into a sample holder for the EXAFS measurements. The absorption spectroscopy data were collected in fluorescence mode using a passivated implanted planar silicon (PIPS) detector (Canberra). The sample was positioned at $45^{\circ}$ and the detector at $90^{\circ}$ to the incident X-ray beam direction. For data analyses, two standard reference materials were used: $\mathrm{MoO}_{3}$ and $[(2,4,6$-tri$\mathrm{tBu}) \mathrm{C}_{6} \mathrm{H}_{2} \mathrm{O}_{2} \mathrm{MoO}_{2}$ (denoted as Ref1), which were measured in transmission mode (Figure S9). The transmitted X-ray intensity was measured using an ionization chamber filled with 1150 Torr $\mathrm{He} / 250$ Torr $\mathrm{N}_{2}$ placed behind the sample. Energy scans were excuted from $300 \mathrm{eV}$ below to 750 $\mathrm{eV}$ above the Mo K edge. The X-ray absorption data were processed using the Demeter:Athena 
software. For EXAFS analyses, the Demeter:Artemis software was used and the $\mathrm{MoO}_{3}$ standard was used for EXAFS phase and amplitude calibration. The data fittings were carried in the Rspcae using the $\mathrm{k}_{2}$-weighted EXAFS spectra. Fig. S9 shows the Mo K-edge of the species $A$, the $\mathrm{MoO}_{3}$ standard and Ref1 standard. Note that the edge positions, defined as the inflection point or the first maximum in the first derivative of the edge, are referenced to that of metal Mo which is at $20,000 \mathrm{eV}$. On overall the edge shape and position (19990-20020 eV) of the speices A (and others shown in Fig. S10) compares well with those of Ref1 and $\mathrm{MoO}_{3}$, implying that the Mo ions in the $\mathrm{AC} / \mathrm{MoO}_{2}$ samples are of $\mathrm{Mo}(\mathrm{VI})$. Upon close inspection the sample edge is $\sim 0.6 \mathrm{eV}$ higher than that of Ref1, but $\sim 1.2 \mathrm{eV}$ lower than that of $\mathrm{MoO}_{3}$. In addition, the leading $\mathrm{K}$ edge, following the pre-edge peaks $(1 s \rightarrow 4 d)$, of the species A overlaps with that of the Ref1 standard. We attribute these differences to the variations in the electronic screening conditions [see, e.g., Shadle $S E$, Penner-Hahn J E, Schugar H J, Hedman B, Hodgson K O and Solomon E I 1993 J. Am. Chem. Soc. 115 767] around $\mathrm{Mo}(\mathrm{VI})$ and argue that the detailed electronic emvironment around $\mathrm{Mo}(\mathrm{VI})$ in the sample is closer, probably unsurprsingly, to that around $\mathrm{Mo}(\mathrm{VI})$ in the Ref1.

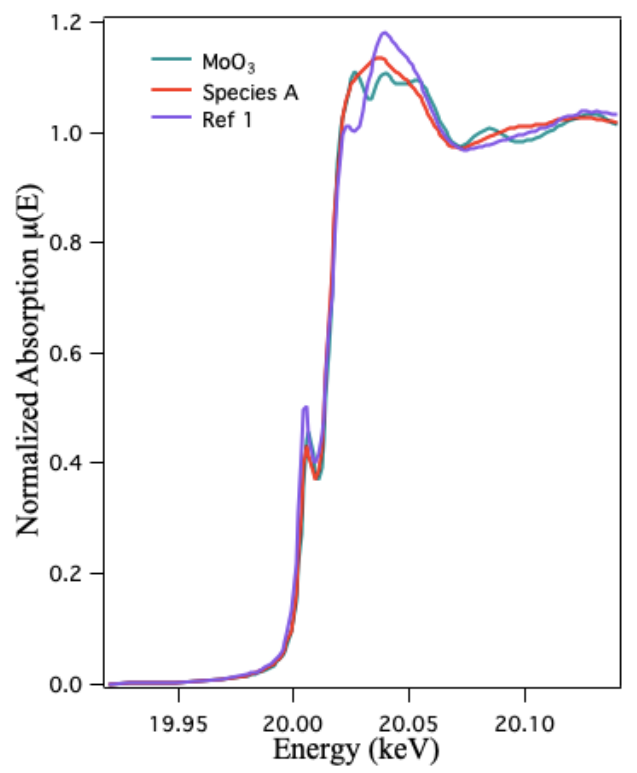

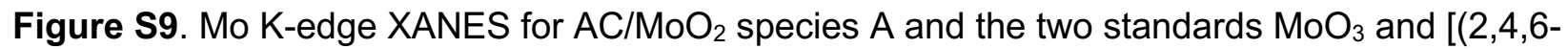
tri-tBu) $\mathrm{C}_{6} \mathrm{H}_{2} \mathrm{O}_{2} \mathrm{MoO}_{2}$ (Ref1 standard). The edge positions are referenced to $20,000 \mathrm{eV}$ of metallic Mo.

\section{Catalyst Atomistic Structure}

For further understanding the $\mathrm{AC} / \mathrm{MoO}_{2}$ microstructure, EXAFS measurements were performed at the Advanced Photon Source 5-BM-D beamline. The EXAFS fitting of freshly prepared $\mathrm{AC} / \mathrm{MoO}_{2}$ samples reveals two $\mathrm{M}=\mathrm{O}$ bonds at a distance of $1.68 \AA$ and two Mo-O bonds at distances of $1.84 \AA$ and $2.53 \AA$, similar to that reported previously ${ }^{1}$ and confirming the consistency in sample preparation, data collection, and analysis. When the sample was heat treated at $250^{\circ} \mathrm{C}$, the longer non-equivalent Mo-O bonds evolved into two Mo-O bonds at a distance of $1.88 \AA$, 
suggesting the formation of a more stable Mo species A. This species is used for later EXAFS experiments and for DFT modelling.

For better understanding of the surface species and the reaction intermediates, five different treated $\mathrm{AC} / \mathrm{MoO}_{2}$ samples were prepared and characterized with XANES and EXAFS (Figure S10, Figure 4, and Table 2). The catalyst is first placed under vacuum at $250{ }^{\circ} \mathrm{C}$ for $90 \mathrm{~h}$ to mimic the initial state (Entry 1 in Table 2, species A in Scheme 2, Figure 4, and Figure S10). To prepare the second sample, $60 \mathrm{mg}$ of the heated-treated sample is mixed with $2.0 \mathrm{~mL}$ tert-butanol placed under $\mathrm{Ar}$ at $50{ }^{\circ} \mathrm{C}$ with stirring rate of $400 \mathrm{rpm}$ for $3 \mathrm{~h}$. The resulting sample is shown in table 2 entry 2 (also in Scheme 2, Figure 4, Figure S10). For the third sample, the catalyst is recycled as described in the recyclability test section above (Table 2 entry 4 , species recycled $A$ in Figure 4 and S10). For the fourth sample, $60 \mathrm{mg}$ of the heated-treated sample is mixed with $0.5 \mathrm{~mL}$ deionized water and stirred at room temperature for $3 \mathrm{~h}$, mimicking species $\mathbf{F}$ in Scheme 2 and Figure 4, and is labeled as species $\mathbf{F}$ in Figure $S 10$ and shown in table 2 entry 4 and Figure 4. For the last one, the same procedures for preparing tert-butanol treated sample is performed and then the resulting sample is placed under vacuum at $200{ }^{\circ} \mathrm{C}$. The result is shown in Figure $\mathrm{S} 11$. Figure 4 and S11 are normalized to one standard for easy comparison.

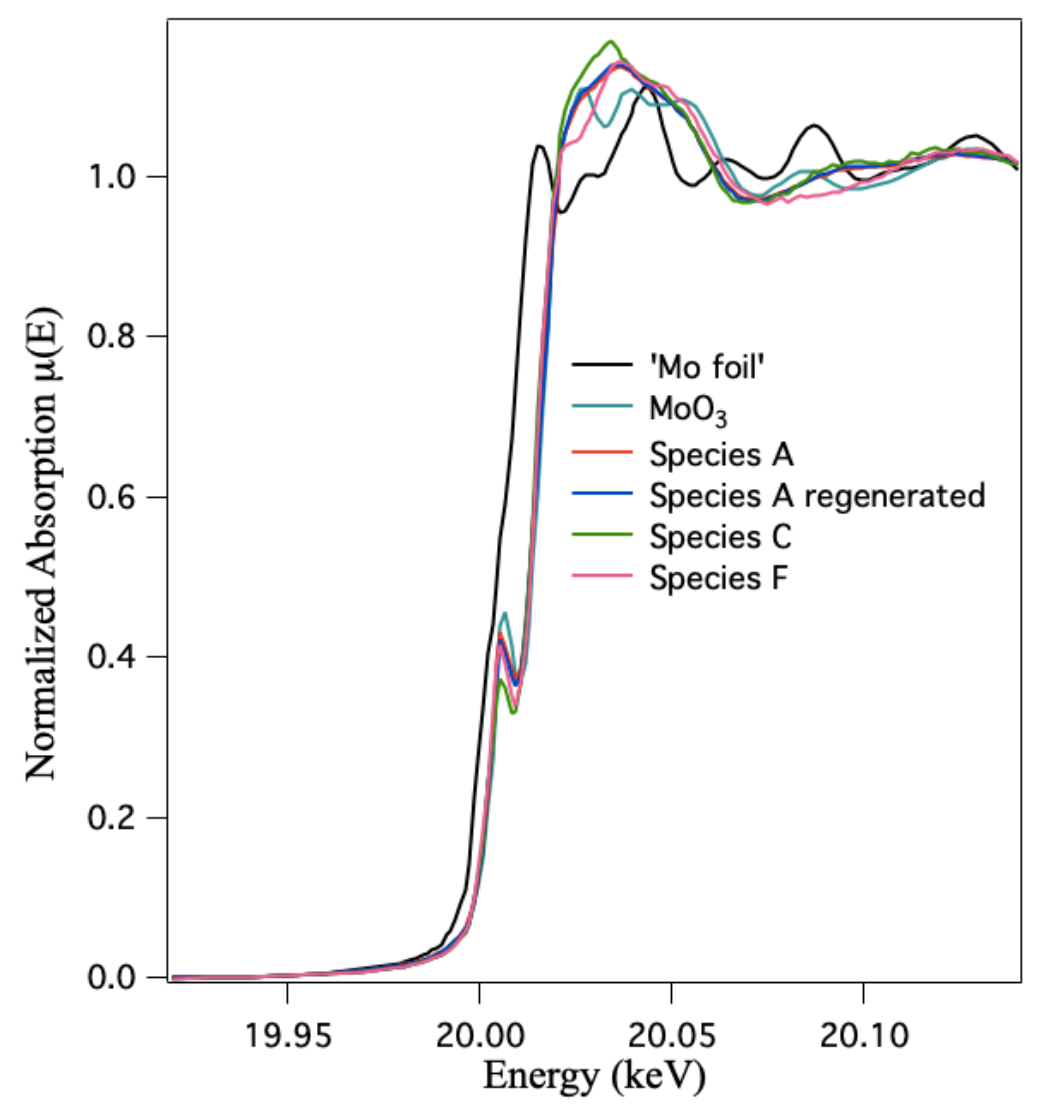

Figure S10. Mo K-edge XANES of species A, C, F, and A (regenerated). Mo(VI) prevails in all the samples. 

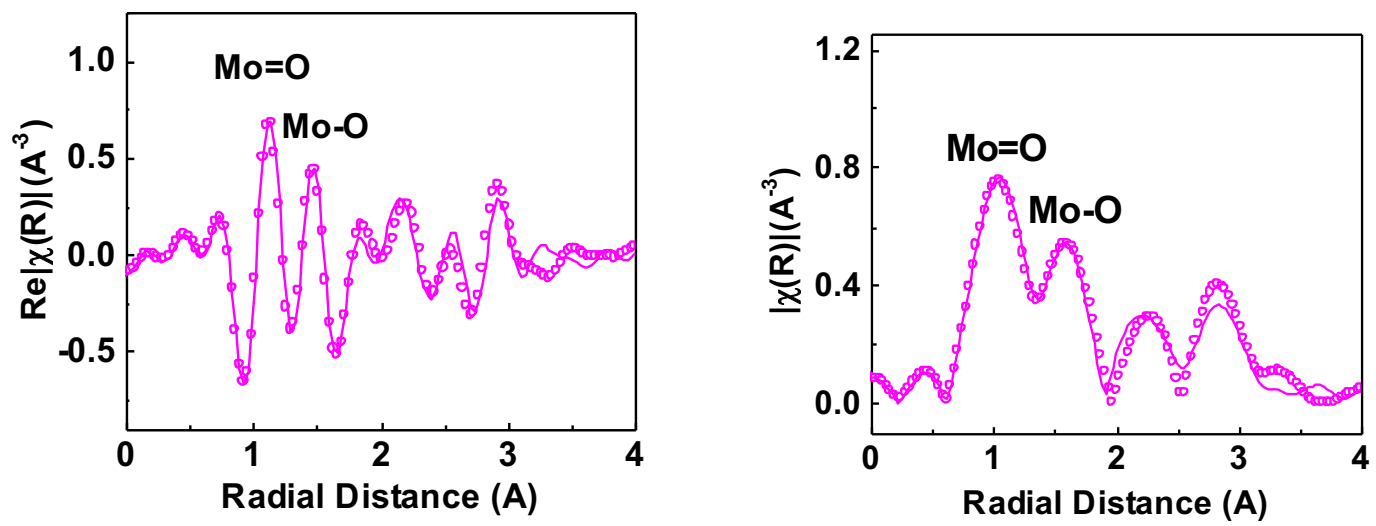

Figure S11. Mo K-edge EXAFS fitting results (pRDF real part on the left and magnitude on the right) of the tert-butanol and vacuum treated $\mathrm{AC} / \mathrm{MoO}_{2}$ surface species. Experimental data is shown in line and the fitting is in dot.

\section{Examplary Analysis Between EXAFS data and DFT result}

As seen from DFT, species $\mathbf{C}$ has one $\mathrm{Mo}=\mathrm{O}$ and four Mo-O bonds whereas species $\mathbf{F}$ has two $\mathrm{Mo}=\mathrm{O}$ and three Mo-O bonds. We see the same trend in the EXAFS data as well. If we compare the EXAFS plots of species $\mathbf{C}$ and species $\mathbf{F}$, the peak at lower Radial Distance $\mathbf{R}$ (which is from the $\mathrm{Mo}=\mathrm{O}$ bonds) is stronger in species $\mathbf{F}$ than in species $\mathbf{C}$ since species $\mathbf{F}$ has more $M o=0$ bonds. Similarly the second peak (which is from Mo-O bonds) is stronger in species $\mathbf{C}$ than in species $\mathbf{F}$ because species $\mathbf{C}$ has more Mo-O bonds. Thus the peak intensities indicate the same behavior as we see from DFT. Finally, the EXAFS fitting routine gives the bond lengths and coordination mentioned in Table 2.

\section{Kinetic Analysis}

The 3-ethyl-3-pentanol to 3-ethyl-2-pentene conversion was chosen as the model reaction for kinetic analysis because of the moderate reaction rate. The analysis was carried out by collecting multiple data points at low conversion $(<20 \%)$ under varied conditions. Substrate conversion and product yield were measured by ${ }^{1} \mathrm{H}-\mathrm{NMR}$ integration vs mesitylene as internal standard. The catalyst concentration was varied from $0.12 \mathrm{~mol} \%$ to $0.90 \mathrm{~mol} \%$ (relative to substrate). For each experiment, $p$-xylene $(1.0 \mathrm{~mL})$ and mesitylene $(0.070 \mathrm{~mL})$ were added as solvent and internal standard, resectively. All experiments were performed at least in triplicate. Data obtained were used to obtain the initial reaction rate according to eq. $S 1$ where $t$ is time, $\left[M_{0}\right]$ is the catalyst concentration, rate is the reaction rate, $v_{\text {substrate }}$ is the stoichiometric substrate coefficient. The initial rate was then used to plot $\ln \left(\right.$ rate) against $\ln \left[\mathrm{M}_{0}\right]$ (eq. S2). The negative rate of substrate disappearance is proportional to the catalyst amount to the order $\alpha$. Thus, the order is the slope of the plot (eq. S3).

$$
\begin{aligned}
& {[\mathrm{Mo}]=\text { rate } \times t} \\
& \text { rate }=-\frac{1}{v_{\text {substrate }}} \frac{d[\text { substrate }]}{d t}=k_{\text {obs }} \times[\mathrm{Mo}]^{\alpha} \\
& \ln (\text { rate })=\ln \left(k_{\text {obs }}\right)+\alpha \ln [\mathrm{Mo}]
\end{aligned}
$$




\section{Determination of [3-ethyl-3-pentanol] reaction order}

The $25 \mathrm{~mL}$ J-Young tube was charged with 3-ethyl-3-pentanol $(0.14 \mathrm{~mL}, 1 \mathrm{mmol}), \mathrm{AC} / \mathrm{MoO}_{2}(0.50$ $\mathrm{mol} \% \mathrm{Mo}, 12.5 \mathrm{mg}$ of $3.82 \mathrm{wt} \%)$, mesitylene $(0.14 \mathrm{~mL}, 1 \mathrm{mmol}), 1.0 \mathrm{~mL}$-xylene, and a PTFE coated magnetic stir bar in air. The solution was degassed and placed under Ar. While stirring at $400 \mathrm{rpm}$, the flask was lowered into an oil bath at $100{ }^{\circ} \mathrm{C}$. Small aliquots of the solution were collected every $15 \mathrm{~min}$ and added to $0.5 \mathrm{~mL} \mathrm{DCM}-\mathrm{d}_{2}$ for ${ }^{1} \mathrm{H}-\mathrm{NMR}$ analysis. Conversion and yield were determined from the starting substrate consumption and the product to mesitylene internal standard ratio by ${ }^{1} \mathrm{H}-\mathrm{NMR}$. A linear relationship with slope of $13.4 \pm 0.7$ is observed in Figure S12.

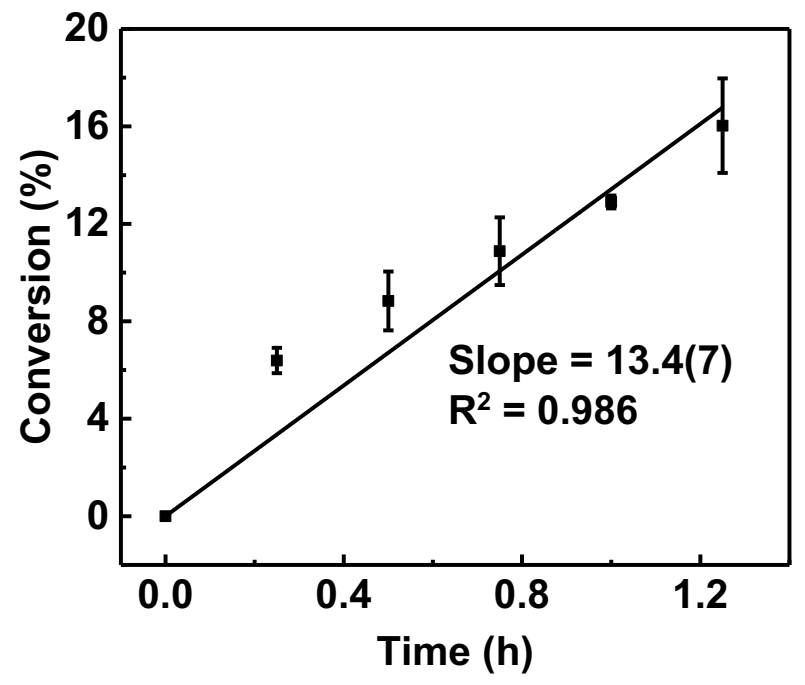

Figure S12. Plot of substrate conversion against time at $100{ }^{\circ} \mathrm{C}$.

\section{Determination of $\left[\mathrm{AC} / \mathrm{MoO}_{2}\right]$ order}

Three $25 \mathrm{~mL}$ J-Young tubes were each charged with 3-ethyl-3-pentanol $(0.14 \mathrm{~mL}, 1 \mathrm{mmol})$, $\mathrm{AC} / \mathrm{MoO}_{2}$ (desired amount, $0.12-0.90 \mathrm{~mol} \% \mathrm{Mo}, 3 \mathrm{mg}-22.5 \mathrm{mg}$ of $3.82 \mathrm{wt} \%$ ), mesitylene $(0.14$ $\mathrm{mL}, 1 \mathrm{mmol}), 1.0 \mathrm{~mL}$-xylene, and a PTFE coated magnetic stir bar in air, then degassed and placed under Ar. While stirring at $400 \mathrm{rpm}$, the tube was lowered into an oil bath at $100{ }^{\circ} \mathrm{C}$. A small portion of the solution was collected every $15 \mathrm{~min}$ and added to $0.5 \mathrm{~mL} \mathrm{DCM}-\mathrm{d}_{2}$ for ${ }^{1} \mathrm{H}-\mathrm{NMR}$ analysis. Conversion and yield were determined from the consumption of the starting substrate and the product to mesitylene internal standard by ${ }^{1} \mathrm{H}-\mathrm{NMR}$. A slope of $1.1 \pm 0.2$ is extracted as shown in figure $\mathrm{S} 13$. 


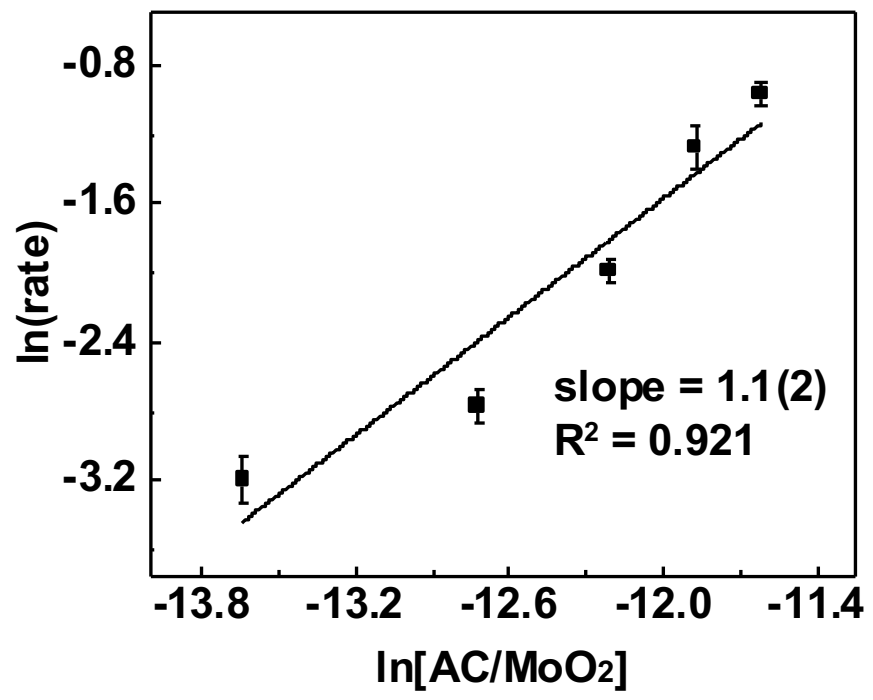

Figure S13. Plot of reaction rate law order in $\left[\mathrm{AC} / \mathrm{MoO}_{2}\right]$ at $100{ }^{\circ} \mathrm{C}$.

\section{Eyring Analysis and Activation Parameters}

The initial reaction rate was measure at 5 temperatures $\left(80^{\circ} \mathrm{C}, 90^{\circ} \mathrm{C}, 100^{\circ} \mathrm{C}, 110{ }^{\circ} \mathrm{C}, 120{ }^{\circ} \mathrm{C}\right)$ at low conversion (<20\%). For each temperature, at least 3 runs were performed. For each run, a $25 \mathrm{~mL}$ J-Young tube was charged with 3-ethyl-3-pentanol $(0.14 \mathrm{~mL}, 1 \mathrm{mmol}), \mathrm{AC} / \mathrm{MoO}_{2}(0.50 \mathrm{~mol} \%$ Mo, $12.5 \mathrm{mg}$ of $3.82 \mathrm{wt} \%)$, mesitylene $(0.14 \mathrm{~mL}, 1 \mathrm{mmol}), 1.0 \mathrm{~mL}$-xylene, and a PTFE coated magnetic stir bar in air, then degassed and placed under Ar. While stirring at $400 \mathrm{rpm}$, the tube was lowered into an oil bath at the target temperature. A small portion of the solution was collected periodically and added to $0.5 \mathrm{~mL}$ DCM- $\mathrm{d}_{2}$ for ${ }^{1} \mathrm{H}-\mathrm{NMR}$ analysis. Conversion and yield were determined from the consumption of the starting substrate and the product to mesitylene internal standard by ${ }^{1} \mathrm{H}-\mathrm{NMR}$. The results are summarized in Table S5.

Table S5. Eyring Plot and Arrhenius Plot Data

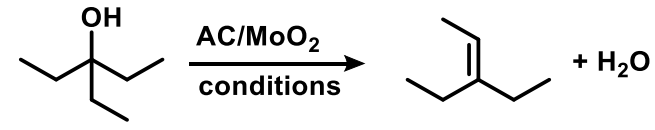

\begin{tabular}{lllll}
\hline Entry & $\mathrm{T}(\mathrm{K})$ & $1 / \mathrm{T}\left(\mathrm{K}^{-1}\right)$ & $\ln (\mathrm{k} / \mathrm{T})$ & $\ln (\mathrm{k})$ \\
\hline 1 & 353.15 & 0.00283 & -12.649 & -6.783 \\
2 & 353.15 & 0.00283 & -12.809 & -6.943 \\
3 & 353.15 & 0.00283 & -12.679 & -6.813 \\
\hline 4 & 363.15 & 0.00275 & -12.565 & -6.671 \\
5 & 363.15 & 0.00275 & -12.552 & -6.656 \\
6 & 363.15 & 0.00275 & -12.244 & -6.350 \\
\hline 7 & 373.15 & 0.00268 & -10.892 & -4.971 \\
8 & 373.15 & 0.00268 & -10.799 & -4.878 \\
9 & 373.15 & 0.00268 & -10.928 & -5.006 \\
\hline 10 & 383.15 & 0.00261 & -9.927 & -3.979
\end{tabular}




\begin{tabular}{lllll}
11 & 383.15 & 0.00261 & -10.033 & -4.085 \\
12 & 383.15 & 0.00261 & -10.219 & -4.271 \\
\hline 13 & 393.15 & 0.00254 & -9.622 & -3.648 \\
14 & 393.15 & 0.00254 & -9.473 & -3.499 \\
15 & 393.15 & 0.00254 & -9.370 & -3.396 \\
\hline
\end{tabular}

$\mathrm{T}=$ temperature in degrees $\mathrm{K}, \mathrm{k}=$ rate constant

\section{Activation Parameters}

Activation Parameters were calculated from Eyring analysis (Figure S14) for the conversion of 3-ethyl-3-pentanol to 3-ethyl-2-pentene at different temperatures. Brackets indicate \pm calculated at the $95 \%$ confidence level. Activation parameters were calculated using the following Eyring equation $\left(T=\right.$ temperature in degrees $\mathrm{K}, \mathrm{k}=$ rate constant, $\mathrm{R}=$ gas constant, $\mathrm{k}_{\mathrm{B}}=$ Boltzmann constant, $\mathrm{h}=$ Planck's constant).

$$
\begin{gathered}
\ln \left(\frac{k}{T}\right)=-\frac{\Delta H^{\neq}}{R} \times \frac{1}{T}+\frac{\Delta S^{\neq}}{R}+\ln \left(\frac{k_{B}}{h}\right) \\
\Delta H^{\neq}=24.4(5) \mathrm{kcal} \cdot \mathrm{mol}^{-1} \\
\Delta S^{\neq}=-3.88(8) \mathrm{cal} \cdot \mathrm{mol}^{-1} \cdot \mathrm{K}^{-1}
\end{gathered}
$$

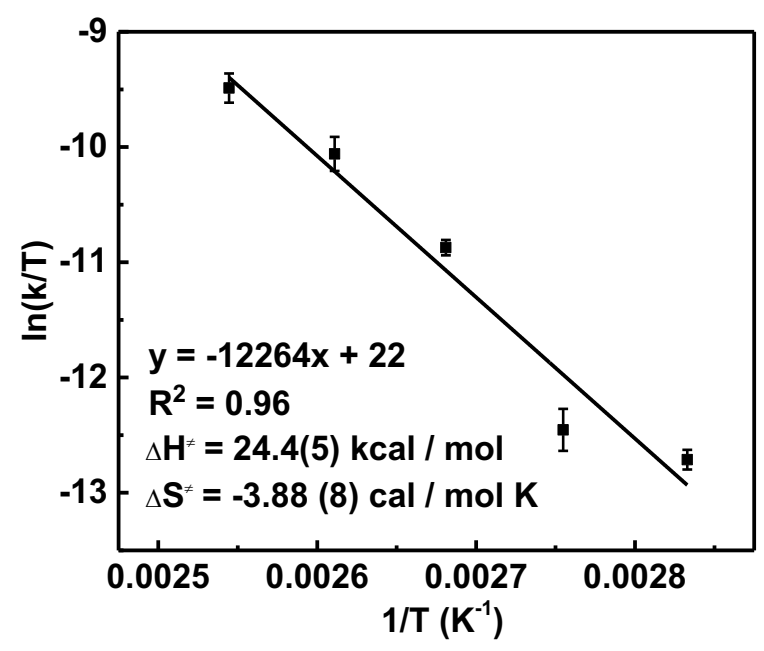

Figure S14. Eyring plot for 3-ethyl-3-pentanol dehydration.

\section{Arrhenius Plot and Activation Energy}

Activation energy are calculated from Arrhenius plot (Figure S15) for the conversion of 3-ethyl3-pentanol to 3-ethyl-2-pentene at different temperatures. Brackets indicate \pm calculated at the $95 \%$ confidence level. Activation energy was calculated using the following Arrhenius equation ( $\mathrm{T}$ = temperature, $\mathrm{k}=$ rate constant, $\mathrm{R}=$ gas constant).

$$
\begin{aligned}
& \ln (k)=-\frac{E_{a}}{R} \times \frac{1}{T}+\ln (A) \\
& E_{a}=25.1(5) \mathrm{kcal} \cdot \mathrm{mol}^{-1}
\end{aligned}
$$




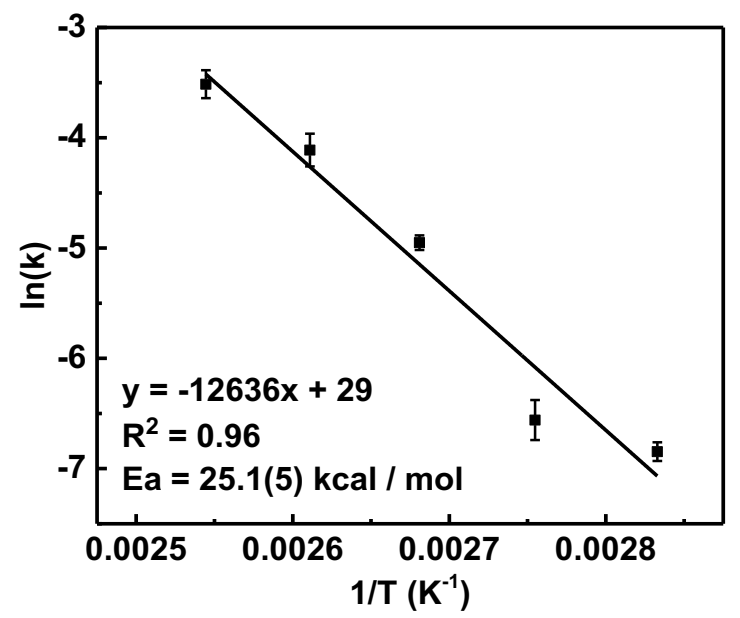

Figure S15. Arrhenius plot of 3-ethyl-3-pentanol dehydration to 3-ethyl-2-pentene.

\section{Error Analysis Procedure}

The errors reported for activation parameters were determined using Regression Analysis workbook in Excel (R. Carr, Deakin University, Australia and Neville Hunt, Coventry University, UK as part of the OATBRAN project). All data is reported at the $95 \%$ confidence interval.

\section{Kinetic Isotopic Effect (KIE)}

The tert-butanol to iso-butene conversion was chosen as the model reaction for the KIE determination. The reactions were performed as described previously. The analysis was carried out by collecting multiple data points at low conversion $(<20 \%)$. Tert-butanol conversions were measured by ${ }^{1} \mathrm{H}-\mathrm{NMR}$ integration vs mesitylene as internal standard and tert-butanol-d 9 conversions were measured by ${ }^{2} \mathrm{H}-\mathrm{NMR}$ integration vs toluene- $\mathrm{d}_{8}$ as internal standard. The product (iso-butene) was detected by ${ }^{1} \mathrm{H}-\mathrm{NMR}$ (Figure S16, 4.81 and $1.82 \mathrm{ppm}$ ) and GC/MS (m/z: 41 and 56 ) but not used for quantification because of its low boiling point $\left(-7^{\circ} \mathrm{C}\right)$. Data obtained were used to calculate the conversions. The initial rates were obtained as the slope in the conversion-time plot (Figure S17). 


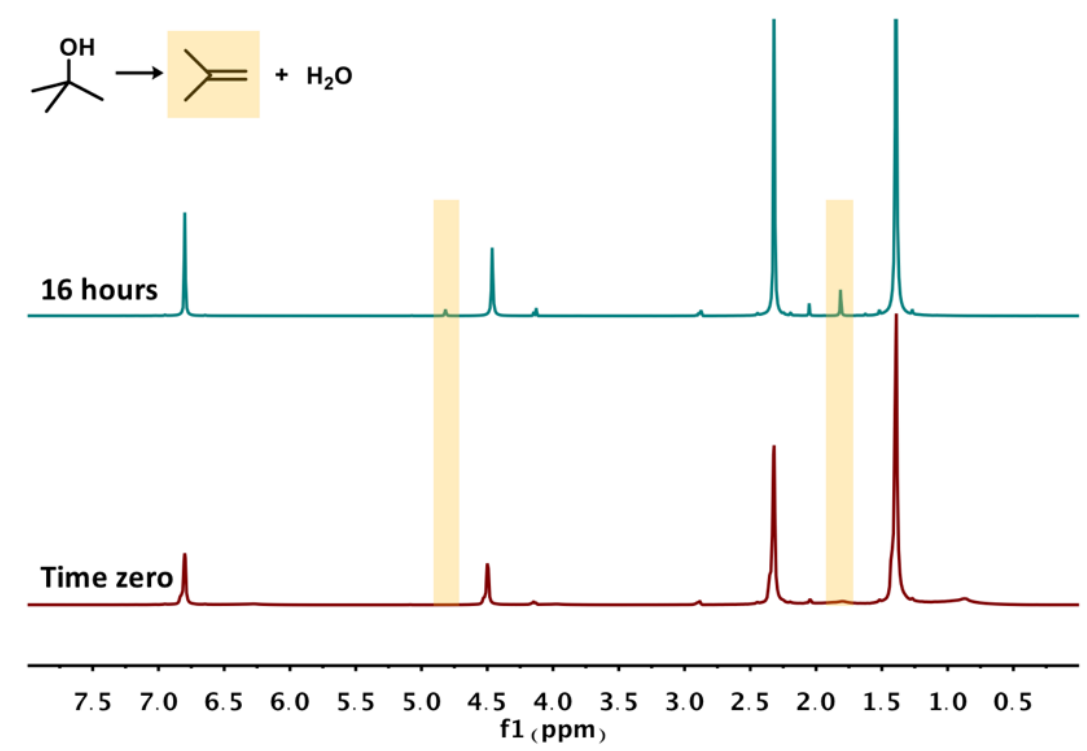

Figure S16. $\delta$ 0.0-8.0 ppm range of H-NMR spectra at time zero and $16 \mathrm{~h}$ points of tert-butanol conversion.

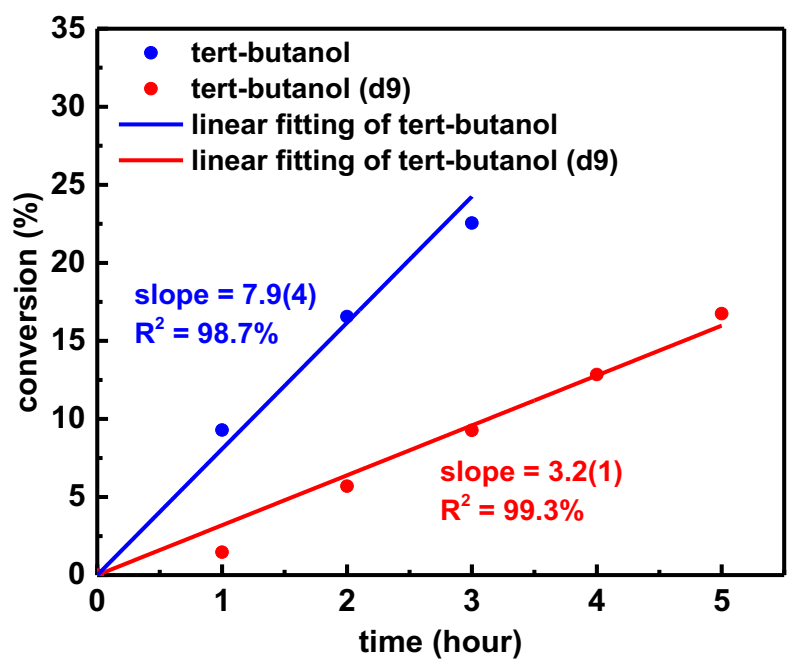

Figure S17. $\mathrm{KIE}$ for $\mathrm{AC} / \mathrm{MoO}_{2}$ catalyzed tert-butanol dehydration

\section{Computational Methodology}

All quantum chemical calculations were performed using the ORCA 4.1.0 software package. ${ }^{27}$ The geometries were calculated at the CAM-B3LYP/Def2-SVP level of theory (frequency calculations at the same level were performed to validate each structure as a minimum or a transition state), followed by single-point calculations with a higher level of theory CAM-B3LYPD3/Def2-TZVP and SMD solvation model (decalin as solvent) for more accurate energetic values. IRC (internal reaction coordinate) calculations starting from the transition structures were performed and verified the reactants and products.

The final free energy values are calculated by the Eq. 1: 
$G=E^{e l}(M 2)+\left[G(M 1)-E^{e l}(M 1)\right]+\Delta G^{1 a t m \rightarrow 1 M}$

$\Delta G^{1 a t m \rightarrow 1 M}=R T \ln (24.46)=1.89 \mathrm{kcal} / \mathrm{mol}(T=298.15 \mathrm{~K})$

Methods: M1: CAM-B3LYP/Def2-SVP/gas phase; M2: CAM-B3LYP-D3/Def2-

TZVP/SMD(decalin).

$E^{\mathrm{el}}(M 2)=$ electronic energy computed with method $M 2 ;\left[G(M 1)-E^{e l}(M 1)\right]=$ thermodynamic corrections obtained with a frequency calculation of the optimized structure with method M1; $\Delta \mathrm{G}^{1 \mathrm{~atm} \rightarrow 1 \mathrm{M}}$ is energy change going from the state of $1 \mathrm{~mol}$ of an ideal gas at $1 \mathrm{~atm}$ to the $1 \mathrm{M}$ solution-phase standard state, which is $1.89 \mathrm{kcal} / \mathrm{mol}$ at $298 \mathrm{~K}$ (eq. 2 ). ${ }^{28}$

\section{Computational Details for Non-Water-Assisted Pathway}

In the non-water-assisted pathway, the first two steps are the same, i.e., alcohol adsorption and proton transfer, generating Mo-oxo-hydroxyl-alkoxide (Scheme 2, species C). Next comes $\beta$-H migration, where the $\beta-\mathrm{H}$ in the activated alkoxide interacts with the oxygen atom of the neighboring $\mathrm{OH}$ moiety, in the form of a six-membered ring (Scheme 2, species TS2', enthalpy barrier $28.4 \mathrm{kcal} / \mathrm{mol}$ ). ${ }^{29}$ Then, the $\beta-\mathrm{H}$ is transferred to the hydroxy group, concurrent with $\mathrm{C}-\mathrm{O}$ cleavage, yielding an oxo group, a coordinated water molecule, and a free isobutene molecule (Scheme 2 species D', $5.2 \mathrm{kcal} / \mathrm{mol}$ ). A similar O-assisted transition state for $\beta-\mathrm{H}$ transfer and concerted $\mathrm{C}-\mathrm{O}$ and $\mathrm{C}-\mathrm{H}$ cleavage pathways have been proposed in the $\left(\mathrm{MO}_{3}\right)_{3}(\mathrm{M}=\mathrm{Mo}, \mathrm{W})$ catalytic systems. ${ }^{30-32}$ The activation enthalpy for the non-water-assisted pathway is calculated to be $33.2 \mathrm{kcal} / \mathrm{mol}$. The kinetic isotope effect calculated for this pathway is 4.9 . Table 56 shows the computational enthalpy and Gibbs free energy profile of the proposed non-water-assisted pathway for tert-butanol dehydration catalyzed by $\mathrm{AC} / \mathrm{MoO}_{2}$.

Table S6. Computed solution-phase enthalpy and Gibbs free energy profile for each species relative to species $\mathrm{A}+\mathrm{t}-\mathrm{BuOH}$ in $\mathrm{kcal} / \mathrm{mol}$ for the non-water-assisted pathway for tert-butanol dehydration catalyzed by $\mathrm{AC} / \mathrm{MoO}_{2}$.

\begin{tabular}{ccc}
\hline Species & $\Delta \mathrm{H}(\mathrm{kcal} / \mathrm{mol})$ & $\Delta \mathrm{G}(\mathrm{kcal} / \mathrm{mol})$ \\
\hline B & -11.2 & 0.2 \\
TS1 & 9.0 & 21.4 \\
C & -6.4 & 4.5 \\
TS2' & 22.0 & 33.3 \\
D' & 5.2 & 4.3 \\
\hline
\end{tabular}

\section{Computational Details for Water-Assisted Pathway}

Table S7 shows the computational enthalpy and Gibbs free energy profile of the proposed water-assisted pathway for tert-butanol dehydration catalyzed by $\mathrm{AC} / \mathrm{MoO}_{2}$.

Table S7. Computed solution-phase enthalpy and Gibbs free energy profile for each species relative to species $\mathrm{A}+\mathrm{tBuOH}$ in $\mathrm{kcal} / \mathrm{mol}$ for the non-water-assisted pathway for tert-butanol dehydration catalyzed by $\mathrm{AC} / \mathrm{MoO}_{2}$.

\begin{tabular}{ccc}
\hline Step & $\Delta \mathrm{H}(\mathrm{kcal} / \mathrm{mol})$ & $\Delta \mathrm{G}(\mathrm{kcal} / \mathrm{mol})$ \\
\hline$B$ & -11.2 & 0.2 \\
\hline
\end{tabular}




\begin{tabular}{ccc}
\hline TS1 & 9.0 & 21.4 \\
C & -6.4 & 4.5 \\
D & -21.3 & 6.7 \\
TS2 & 5.0 & 34.0 \\
E & -21.3 & 4.8 \\
F & -15.2 & 1.1 \\
\hline
\end{tabular}

\section{Computational Details for Water Coordination}

According to the computational data, the formation of $\mathrm{AC} / \mathrm{Mo}(\mathrm{OH})_{2}$ from $\mathrm{AC} / \mathrm{MoO}_{2}$ and water is endothermic by $\Delta \mathrm{H}=5.4 \mathrm{kcal} / \mathrm{mol}$, while $\mathrm{AC} / \mathrm{Mo}(\mathrm{OH})(\mathrm{OtBu})$ is exothermic by $\Delta \mathrm{H}=-6.3$ $\mathrm{kcal} / \mathrm{mol}($ Scheme S3). These results indicate that in the presence of $\mathrm{tBuOH}$ and water, the formation of Brønsted acidic $\mathrm{AC} / \mathrm{Mo}(\mathrm{OH})_{2}$ species is energetically not favorable. In addition, the formation of the experimentally observed complex $\mathrm{AC} / \mathrm{MoO}_{2} \cdot 3 \mathrm{H}_{2} \mathrm{O}(\mathbf{F})$ when water is added to $\mathrm{AC} / \mathrm{MoO}_{2}$ is lower by $34.9 \mathrm{kcal} / \mathrm{mol}$ compared to $\mathrm{AC} / \mathrm{Mo}(\mathrm{OH})_{2}$, supporting that formation of Brønsted acidic in the single-site $\mathrm{MoO}_{2}$ catalyst is not likely (Scheme S3).
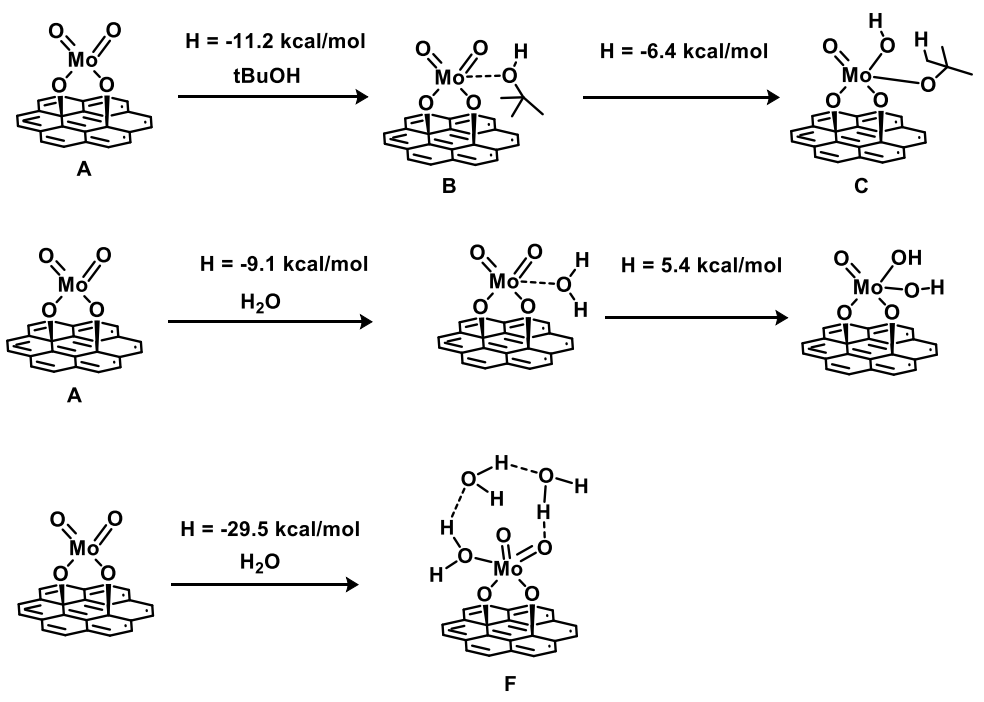

Scheme S3. The thermodynamics of water and ${ }^{\mathrm{t}} \mathrm{BuOH}$ coordination to $\mathrm{AC} / \mathrm{MoO}_{2}$.

\section{Computational Details for Proton Transfer To Terminal Oxygen}

According to the computational data, $\mathrm{H}$ from the methyl group to a terminal oxygen atom in $\mathrm{Mo}=\mathrm{O}$ is $6.4 \mathrm{kcal} / \mathrm{mol}$ higher in enthalpy compared to $\mathrm{H}$ transfer to an oxygen atom in the Mo-OH moiety (Scheme S4). The KIE for the corresponding terminal oxygen transfer pathway is 6.1, while the experimental value is 2.7 , and that for the calculated $\mathrm{OH}$ pathway is 4.9 . This far worse agreement supports the contention that proton transfer through the terminal oxygen is unlikely. 


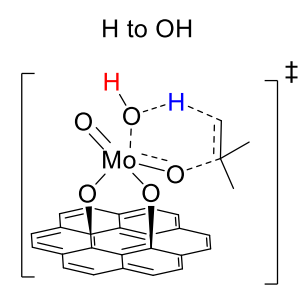

TS2 - OH vs

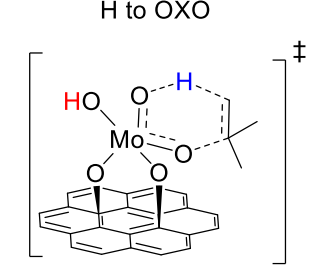

TS2 - oxo

Scheme S4. The structure of transition state of different pathways.

\section{Optimized Cartesian coordinates for each species} species $A$
C $\quad 1.159778000$
0.691942000
$-0.283032000$
C $\quad-0.086030000$
1.429849000
0.162412000
C -1.356419000
0.684543000
$-0.176285000$
C -1.356832000
$-0.683744000$
$-0.176278000$
C $\quad-0.086894000$
$-1.429813000$
0.162435000
C $\quad 1.15936000$
$-0.692666000$
$-0.283018000$
C $\quad-2.582907000$
$-1.421410000$
$-0.327737000$
C -2.537442000
$-2.806229000$
$-0.379288000$
C -1.319004000
$-3.514929000$
$-0.368606000$
C $\quad-0.104967000$
$-2.885127000$
$-0.233925000$
C $\quad 1.142678000$
$-3.542382000$
$-0.403289000$
C $\quad 2.312226000$
$-2.848999000$
$-0.523258000$
C 2.350236000
$-1.416075000$
$-0.520276000$
C $\quad 3.532973000$
$-0.689587000$
$-0.765943000$
C $\quad 3.533390000$
0.687422000
$-0.765952000$
C $\quad 2.351091000$
1.414628000
$-0.520297000$
C 2.313946000
2.847575000
$-0.523292000$
C $\quad 1.144817000$
3.541666000
$-0.403331000$
C $\quad-0.103226000$
2.885168000
$-0.233967000$
C -1.316883000
3.515702000
$-0.368658000$
C $\quad-2.535748000$
2.807738000
$-0.379330000$
C $\quad-2.582048000$
1.422948000
$-0.327755000$
C $\quad-3.801586000$
0.680314000
$-0.457078000$
C $\quad-3.801997000 \quad-0.678041000$
$-0.457069000$
Mo
0.542763000
$-0.000154000$
2.683426000 


$\begin{array}{lrrr}\mathrm{O} & -0.068813000 & 1.434668000 & 1.644036000 \\ \mathrm{O} & -0.069697000 & -1.434619000 & 1.644060000 \\ \mathrm{O} & 2.215200000 & -0.000668000 & 2.830359000 \\ \mathrm{O} & -0.125118000 & 0.000097000 & 4.217888000 \\ \mathrm{H} & -3.469491000 & 3.361177000 & -0.501214000 \\ \mathrm{H} & -1.331924000 & 4.596110000 & -0.533084000 \\ \mathrm{H} & -4.736769000 & 1.234283000 & -0.564317000 \\ \mathrm{H} & -4.737514000 & -1.231446000 & -0.564303000 \\ \mathrm{H} & -3.471517000 & -3.359110000 & -0.501163000 \\ \mathrm{H} & -1.334703000 & -4.595331000 & -0.533014000 \\ \mathrm{H} & 1.142278000 & -4.630872000 & -0.500182000 \\ \mathrm{H} & 3.248651000 & -3.386742000 & -0.686950000 \\ \mathrm{H} & 4.459843000 & -1.236661000 & -0.951740000 \\ \mathrm{H} & 4.460590000 & 1.233934000 & -0.951757000 \\ \mathrm{H} & 3.250694000 & 3.384755000 & -0.686985000 \\ \mathrm{H} & 1.145080000 & 4.630157000 & -0.500230000\end{array}$

\section{Species B}

$\begin{array}{lrrr}\text { C } & 0.801992000 & -0.935817000 & -0.926537000 \\ \text { C } & -0.250662000 & 0.112661000 & -0.642200000 \\ \text { C } & -1.648778000 & -0.471938000 & -0.585365000 \\ \text { C } & -1.813354000 & -1.740881000 & -0.064432000 \\ \text { C } & -0.586884000 & -2.488073000 & 0.418837000 \\ \text { C } & 0.639664000 & -2.191304000 & -0.415124000 \\ \text { C } & -3.102971000 & -2.256385000 & 0.197288000 \\ \text { C } & -3.231436000 & -3.569069000 & 0.753440000 \\ \text { C } & -2.150530000 & -4.382194000 & 0.948687000 \\ \text { C } & -0.831643000 & -3.965154000 & 0.634138000 \\ \text { C } & 0.233854000 & -4.830349000 & 0.543381000 \\ \text { C } & 1.482771000 & -4.434512000 & 0.025107000 \\ \text { C } & 1.695875000 & -3.163153000 & -0.488952000 \\ \text { C } & 2.922498000 & -2.771849000 & -1.118367000 \\ \text { C } & 3.084435000 & -1.522200000 & -1.628717000 \\ \text { C } & 2.034503000 & -0.549234000 & -1.557210000\end{array}$




$\begin{array}{llll}\text { C } & 2.150027000 & 0.726979000 & -2.090850000 \\ \text { C } & 1.067150000 & 1.627937000 & -2.108965000 \\ \text { C } & -0.149277000 & 1.326714000 & -1.540302000 \\ \text { C } & -1.313682000 & 2.114378000 & -1.731804000 \\ \text { C } & -2.559145000 & 1.654295000 & -1.406769000 \\ \text { C } & -2.768174000 & 0.341951000 & -0.874839000 \\ \text { C } & -4.054993000 & -0.185621000 & -0.634522000 \\ \text { C } & -4.217830000 & -1.448783000 & -0.111879000 \\ \text { Mo } & -0.413825000 & -0.188774000 & 2.384737000 \\ \text { O } & 0.052040000 & 0.584733000 & 0.699501000 \\ \text { O } & -0.257055000 & -1.943756000 & 1.730803000 \\ \text { O } & 0.702825000 & -0.144964000 & 3.643168000 \\ \text { O } & -1.993497000 & -0.099380000 & 2.975777000 \\ \text { H } & -1.462501000 & 2.151919000 & 3.313823000 \\ \text { H } & 4.024008000 & -1.236969000 & -2.107238000 \\ \text { H } & 3.730537000 & -3.504481000 & -1.180719000 \\ \text { H } & 2.289194000 & -5.169197000 & -0.035973000 \\ \text { H } & 0.085393000 & -5.876488000 & 0.822979000 \\ \text { H } & -2.297711000 & -5.408795000 & 1.292980000 \\ \text { H } & -4.235622000 & -3.938643000 & 0.972698000 \\ \text { H } & -5.220117000 & -1.837493000 & 0.081385000 \\ \text { H } & -4.928255000 & 0.430698000 & -0.860253000 \\ \text { H } & -3.436590000 & 2.273291000 & -1.608125000 \\ \text { H } & -1.204093000 & 3.086099000 & -2.220058000 \\ \text { H } & 1.173669000 & 2.570538000 & -2.652454000 \\ \text { H } & 3.087705000 & 1.013407000 & -2.572831000 \\ \text { O } & -0.639627000 & 2.101398000 & 2.805894000 \\ \text { C } & 0.292589000 & 3.118290000 & 3.258773000 \\ \text { C } & -0.325265000 & 4.469571000 & 2.916787000 \\ \text { H } & -1.288897000 & 4.605393000 & 3.432597000 \\ \text { H } & -0.498426000 & 4.547733000 & 1.834314000 \\ \text { H } & 0.338790000 & 5.289117000 & 3.227837000 \\ \text { C } & 0.500389000 & 2.955824000 & 4.760311000 \\ \text { H } & -0.446236000 & 3.099821000 & 5.305916000\end{array}$




$\begin{array}{llll}\mathrm{H} & 0.881534000 & 1.950675000 & 4.984256000 \\ \mathrm{H} & 1.217272000 & 3.702224000 & 5.132628000 \\ \mathrm{C} & 1.584441000 & 2.895451000 & 2.487046000 \\ \mathrm{H} & 2.301327000 & 3.692954000 & 2.729113000 \\ \mathrm{H} & 2.035020000 & 1.930832000 & 2.756395000 \\ \mathrm{H} & 1.392749000 & 2.898150000 & 1.405640000\end{array}$

\section{Transition state 1 (TS1)}

$\begin{array}{llll}\text { C } & 0.960518000 & -0.703204000 & -0.667793000 \\ \text { C } & -0.013981000 & 0.385109000 & -0.280731000 \\ \text { C } & -1.450748000 & -0.096888000 & -0.258890000 \\ \text { C } & -1.705574000 & -1.398311000 & 0.133602000 \\ \text { C } & -0.535750000 & -2.276480000 & 0.529938000 \\ \text { C } & 0.711869000 & -1.986390000 & -0.270386000 \\ \text { C } & -3.028318000 & -1.843453000 & 0.354826000 \\ \text { C } & -3.249720000 & -3.191612000 & 0.784003000 \\ \text { C } & -2.230114000 & -4.093449000 & 0.894206000 \\ \text { C } & -0.883075000 & -3.743990000 & 0.613163000 \\ \text { C } & 0.119341000 & -4.667960000 & 0.436282000 \\ \text { C } & 1.396000000 & -4.313710000 & -0.046337000 \\ \text { C } & 1.698901000 & -3.018755000 & -0.439443000 \\ \text { C } & 2.949750000 & -2.655705000 & -1.037953000 \\ \text { C } & 3.197683000 & -1.378871000 & -1.432515000 \\ \text { C } & 2.218417000 & -0.345508000 & -1.265046000 \\ \text { C } & 2.424343000 & 0.964764000 & -1.671047000 \\ \text { C } & 1.409521000 & 1.940053000 & -1.591337000 \\ \text { C } & 0.175655000 & 1.674114000 & -1.045588000 \\ \text { C } & -0.929647000 & 2.560018000 & -1.145080000 \\ \text { C } & -2.203874000 & 2.162140000 & -0.855230000 \\ \text { C } & -2.507982000 & 0.821041000 & -0.454804000 \\ \text { C } & -3.827781000 & 0.364836000 & -0.257088000 \\ \text { C } & -4.080536000 & -0.930509000 & 0.137267000 \\ \text { Mo } & -0.338336000 & -0.166486000 & 2.658763000 \\ \text { O } & 0.350735000 & 0.666830000 & 1.106792000\end{array}$




$\begin{array}{lrrr}\text { O } & -0.167821000 & -1.861986000 & 1.890461000 \\ \text { O } & 0.804956000 & -0.066143000 & 3.863879000 \\ \text { O } & -1.971159000 & -0.383821000 & 3.376900000 \\ \text { H } & -2.057275000 & 0.783690000 & 3.432509000 \\ \text { H } & 4.155206000 & -1.116360000 & -1.887731000 \\ \text { H } & 3.705232000 & -3.433114000 & -1.172527000 \\ \text { H } & 2.148320000 & -5.094576000 & -0.179389000 \\ \text { H } & -0.103386000 & -5.722988000 & 0.614852000 \\ \text { H } & -2.450139000 & -5.134436000 & 1.142926000 \\ \text { H } & -4.277356000 & -3.507563000 & 0.976094000 \\ \text { H } & -5.108112000 & -1.262285000 & 0.301254000 \\ \text { H } & -4.655011000 & 1.061638000 & -0.409913000 \\ \text { H } & -3.033697000 & 2.860915000 & -0.983465000 \\ \text { H } & -0.749513000 & 3.565408000 & -1.533608000 \\ \text { H } & 1.585517000 & 2.922027000 & -2.037780000 \\ \text { H } & 3.380758000 & 1.230653000 & -2.126956000 \\ \text { O } & -1.319096000 & 1.702532000 & 2.975437000 \\ \text { C } & -0.916274000 & 2.966938000 & 3.504494000 \\ \text { C } & -2.031848000 & 3.952697000 & 3.164919000 \\ \text { H } & -1.803603000 & 4.957260000 & 3.551665000 \\ \text { H } & -2.982972000 & 3.619835000 & 3.606299000 \\ \text { H } & -2.161646000 & 4.014823000 & 2.074822000 \\ \text { C } & -0.744620000 & 2.834676000 & 5.017167000 \\ \text { H } & -1.689512000 & 2.520081000 & 5.485952000 \\ \text { H } & 0.024535000 & 2.084580000 & 5.252267000 \\ \text { H } & -0.442568000 & 3.792970000 & 5.465823000 \\ \text { C } & 0.394029000 & 3.393604000 & 2.847627000 \\ \text { H } & 1.202564000 & 2.689261000 & 3.090618000 \\ \text { H } & 0.286038000 & 3.424137000 & 1.754844000 \\ \text { H } & 0.691133000 & 4.390797000 & 3.204807000 \\ & & & \end{array}$

\section{Species C}

$\begin{array}{llll}\text { C } & 0.620628000 & -0.985770000 & -0.673898000\end{array}$

$\begin{array}{llll}\text { C } & -0.395311000 & 0.116727000 & -0.463102000\end{array}$ 


$\begin{array}{llll}\text { C } & -1.822386000 & -0.387692000 & -0.520428000 \\ \text { C } & -2.092696000 & -1.632057000 & 0.007140000 \\ \text { C } & -0.938918000 & -2.408181000 & 0.601560000 \\ \text { C } & 0.355423000 & -2.221091000 & -0.161597000 \\ \text { C } & -3.421418000 & -2.080330000 & 0.178214000 \\ \text { C } & -3.653699000 & -3.359732000 & 0.774845000 \\ \text { C } & -2.628296000 & -4.203442000 & 1.101918000 \\ \text { C } & -1.270630000 & -3.859546000 & 0.879175000 \\ \text { C } & -0.247557000 & -4.780360000 & 0.893423000 \\ \text { C } & 1.047940000 & -4.478328000 & 0.430632000 \\ \text { C } & 1.358940000 & -3.246358000 & -0.129209000 \\ \text { C } & 2.642235000 & -2.938236000 & -0.687584000 \\ \text { C } & 2.907050000 & -1.709404000 & -1.206609000 \\ \text { C } & 1.913532000 & -0.676370000 & -1.216425000 \\ \text { C } & 2.139906000 & 0.588619000 & -1.742724000 \\ \text { C } & 1.112139000 & 1.546139000 & -1.840952000 \\ \text { C } & -0.158474000 & 1.314709000 & -1.363009000 \\ \text { C } & -1.260594000 & 2.154643000 & -1.665384000 \\ \text { C } & -2.552937000 & 1.761482000 & -1.448789000 \\ \text { C } & -2.871752000 & 0.471566000 & -0.919457000 \\ \text { C } & -4.199105000 & 0.008120000 & -0.783294000 \\ \text { C } & -4.466959000 & -1.232021000 & -0.247769000 \\ \text { Mo } & -0.196237000 & -0.152070000 & 2.667892000 \\ \text { O } & -0.204253000 & 0.601627000 & 0.884571000 \\ \text { O } & -0.669081000 & -1.780730000 & 1.871741000 \\ \text { O } & 1.382708000 & -0.467984000 & 3.079566000 \\ \text { O } & -1.364256000 & -0.612199000 & 4.084676000 \\ \text { H } & -1.419836000 & -0.019981000 & 4.845679000 \\ \text { H } & 3.891646000 & -1.485638000 & -1.623303000 \\ \text { H } & 3.412142000 & -3.713257000 & -0.679241000 \\ \text { H } & 1.815077000 & -5.255908000 & 0.4548800000 \\ \text { H } & -0.469435000 & -5.803323000 & 1.208245000 \\ \text { H } & -2.849656000 & -5.206083000 & 1.475971000 \\ \text { H } & -4.687538000 & -3.680597000 & 0.921850000\end{array}$




$\begin{array}{lrrr}\text { H } & -5.499764000 & -1.569558000 & -0.134423000 \\ \mathrm{H} & -5.019158000 & 0.656936000 & -1.099779000 \\ \mathrm{H} & -3.376067000 & 2.419011000 & -1.738265000 \\ \mathrm{H} & -1.059639000 & 3.110610000 & -2.155875000 \\ \mathrm{H} & 1.307398000 & 2.476093000 & -2.381601000 \\ \mathrm{H} & 3.123928000 & 0.819597000 & -2.157153000 \\ \mathrm{O} & -0.323447000 & 1.619558000 & 3.197291000 \\ \mathrm{C} & -0.032138000 & 3.002560000 & 3.018343000 \\ \mathrm{C} & -1.125982000 & 3.605244000 & 2.141378000 \\ \mathrm{H} & -2.108437000 & 3.490173000 & 2.623072000 \\ \mathrm{H} & -1.152620000 & 3.097534000 & 1.168446000 \\ \mathrm{H} & -0.942893000 & 4.677925000 & 1.978422000 \\ \mathrm{C} & -0.031683000 & 3.628406000 & 4.411074000 \\ \mathrm{H} & -1.013863000 & 3.504238000 & 4.890604000 \\ \mathrm{H} & 0.729810000 & 3.150946000 & 5.044384000 \\ \mathrm{H} & 0.189984000 & 4.704043000 & 4.348989000 \\ \mathrm{C} & 1.341793000 & 3.126118000 & 2.363000000 \\ \mathrm{H} & 2.108218000 & 2.645734000 & 2.988242000 \\ \mathrm{H} & 1.338957000 & 2.637633000 & 1.379894000 \\ \mathrm{H} & 1.609588000 & 4.185370000 & 2.234351000\end{array}$

\section{Species D}

$\begin{array}{lccc}\text { Mo } & 8.994337000 & -11.179016000 & 3.486924000 \\ \text { O } & 8.139901000 & -12.778984000 & 3.952523000 \\ \text { O } & 10.341012000 & -10.335599000 & 2.364116000 \\ \text { O } & 8.286862000 & -11.418497000 & 1.685956000 \\ \text { O } & 10.292289000 & -11.366541000 & 4.731002000 \\ \text { C } & 11.474079000 & -11.379863000 & 5.544780000 \\ \text { C } & 11.119197000 & -10.672726000 & 6.846641000 \\ \text { H } & 12.005536000 & -10.614897000 & 7.496325000 \\ \text { H } & 10.755048000 & -9.657045000 & 6.629035000 \\ \text { H } & 10.334207000 & -11.229435000 & 7.379277000 \\ \text { O } & 9.828944000 & -7.957005000 & 5.533217000 \\ \text { H } & 10.310729000 & -7.793339000 & 4.698255000\end{array}$




\begin{tabular}{|c|c|c|c|}
\hline & 0 & -8 & \\
\hline & 1.179721000 & -7.841937000 & 96000 \\
\hline & 2.138133000 & $-7.7<$ & 31000 \\
\hline & 8.007709000 & -9.970968000 & 4.062768000 \\
\hline & 1.84570 & -12 & \\
\hline & 0 & -1 & \\
\hline & 0 & -1 & \\
\hline & 12.0 & -13 & 00 \\
\hline & 12.556364000 & -10.629912000 & 490200 \\
\hline & 12.809184000 & 35000 & 3600 \\
\hline & 12.201573000 & 1000 & 4.5 \\
\hline & 00 & -10 & \\
\hline & 10.014 & & \\
\hline & 10. & -8. & 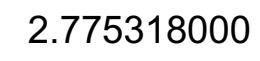 \\
\hline & 2000 & -13.5 & 000 \\
\hline & 5000 & -12 & 1. \\
\hline & 5.987 & -11. & 2. \\
\hline & 00 & -12 & 3. \\
\hline & 0 & -13 & \\
\hline & 00 & -14. & \\
\hline & 00 & -12.313748000 & 4.2 \\
\hline & 4.930971000 & -13.06 & 5.3 \\
\hline & 5.773593000 & -14.176790000 & 5.56 \\
\hline & 714192000 & -14.5 & 4.6 \\
\hline & 73000 & -15. & 3000 \\
\hline & 8.0883610 & -16.287637 & .00 \\
\hline & 144646 & -15.586805 & 3 \\
\hline & & -16.1 & \\
\hline & 00 & -15.4 & 000 \\
\hline & 8.264874000 & -14.106685000 & -0.054 \\
\hline & 8.328944000 & -13.313920000 & -1.244687000 \\
\hline & 00 & -12.1 & -1.34 \\
\hline & 65442000 & -11.548328000 & $-0.26479500 c$ \\
\hline & 086861000 & -10.500043000 & $-0.4168220 c$ \\
\hline
\end{tabular}




\begin{tabular}{|c|c|c|c|}
\hline & 5.188704000 & -10.117201000 & 6000 \\
\hline & 5.089046000 & -10.818065000 & 1.793071000 \\
\hline & 4.113724000 & -10.516473000 & 2.799305000 \\
\hline & 4.048096000 & -11.231737000 & 3.953663000 \\
\hline & 4.503059000 & -9.286383000 & 0.416819000 \\
\hline & 6.035139000 & -9.994733000 & 0000 \\
\hline & 3.424403000 & -9.688232000 & 2.621034000 \\
\hline & 3.305896000 & -10.986183000 & 4.716532000 \\
\hline & 4.195039000 & -12.819951000 & 6.147336000 \\
\hline & 5.629252000 & -14.808137000 & 6.441380000 \\
\hline & 7.303292000 & -16.399477000 & 5.583480000 \\
\hline & 8.564724000 & -17.268593000 & 3.665473000 \\
\hline & 9.210255000 & -17.116716000 & 1.260679000 \\
\hline & 9.313465000 & -15.824511000 & -0.846099000 \\
\hline & 8.849002000 & -13.727060000 & -2.112159000 \\
\hline & 7.703729000 & -11.566502000 & -2.295505000 \\
\hline
\end{tabular}

Transition state 2 (TS2)

$\begin{array}{lccc}\text { Mo } & 9.088907000 & -10.707833000 & 3.014242000 \\ \text { O } & 8.504503000 & -12.424624000 & 3.734604000 \\ \text { O } & 9.852901000 & -9.470158000 & 1.728144000 \\ \text { O } & 8.179340000 & -11.225345000 & 1.323954000 \\ \text { O } & 10.627859000 & -10.876859000 & 3.776251000 \\ \text { C } & 11.290761000 & -11.594363000 & 6.060421000 \\ \text { C } & 10.661887000 & -10.588039000 & 6.866279000 \\ \text { H } & 11.380598000 & -10.102909000 & 7.545082000 \\ \text { H } & 10.409304000 & -9.685617000 & 6.179384000 \\ \text { H } & 9.744746000 & -10.908034000 & 7.373327000 \\ \text { O } & 10.034635000 & -8.215171000 & 5.458287000 \\ \text { H } & 10.658426000 & -8.101839000 & 4.697363000 \\ \text { H } & 9.195702000 & -8.473309000 & 5.035326000 \\ \text { O } & 11.727736000 & -8.327557000 & 3.333339000 \\ \text { H } & 11.840280000 & -9.277217000 & 3.499654000 \\ \text { O } & 8.147378000 & -9.669492000 & 3.954340000\end{array}$




$\begin{array}{llll}\mathrm{C} & 10.651375000 & -12.890047000 & 5.828563000 \\ \mathrm{H} & 10.209767000 & -13.269876000 & 6.761946000 \\ \mathrm{H} & 9.787247000 & -12.746186000 & 5.132985000 \\ \mathrm{H} & 11.322295000 & -13.627384000 & 5.372471000 \\ \mathrm{C} & 12.684018000 & -11.384205000 & 5.614222000 \\ \mathrm{H} & 12.874341000 & -11.875773000 & 4.653233000 \\ \mathrm{H} & 12.957322000 & -10.322233000 & 5.573578000 \\ \mathrm{H} & 13.319329000 & -11.875086000 & 6.376228000 \\ \mathrm{H} & 9.322505000 & -9.420887000 & 0.920959000 \\ \mathrm{H} & 11.125889000 & -8.377011000 & 2.562428000 \\ \mathrm{C} & 7.718004000 & -13.514740000 & 1.017311000 \\ \mathrm{C} & 7.119942000 & -12.122973000 & 0.982488000 \\ \mathrm{C} & 6.036933000 & -11.932518000 & 2.026468000 \\ \mathrm{C} & 6.195516000 & -12.530106000 & 3.242299000 \\ \mathrm{C} & 7.440484000 & -13.361141000 & 3.476507000 \\ \mathrm{C} & 7.873913000 & -14.124546000 & 2.242611000 \\ \mathrm{C} & 5.328133000 & -12.213157000 & 4.341385000 \\ \mathrm{C} & 5.518461000 & -12.851016000 & 5.562026000 \\ \mathrm{C} & 6.479440000 & -13.864964000 & 5.722527000 \\ \mathrm{C} & 7.335258000 & -14.241018000 & 4.708406000 \\ \mathrm{C} & 8.132945000 & -15.411245000 & 4.765780000 \\ \mathrm{C} & 8.744745000 & -15.930716000 & 3.655856000 \\ \mathrm{C} & 8.595645000 & -15.335566000 & 2.365096000 \\ \mathrm{C} & 9.130835000 & -15.914297000 & 1.192749000 \\ \mathrm{C} & 8.976084000 & -15.304059000 & -0.031552000 \\ \mathrm{C} & 8.276100000 & -14.083012000 & -0.150950000 \\ \mathrm{C} & 8.103295000 & -13.413034000 & -1.401607000 \\ \mathrm{C} & 7.334920000 & -12.286865000 & -1.521876000 \\ \mathrm{C} & 6.674207000 & -11.709966000 & -0.409464000 \\ \mathrm{C} & 5.666623000 & -10.778911000 & -0.537391000 \\ \mathrm{C} & 4.860878000 & -10.394288000 & 0.549334000 \\ \mathrm{C} & 4.994274000 & -10.971987000 & 1.806757000 \\ \mathrm{C} & 4.123471000 & -10.666280000 & 2.901542000 \\ \mathrm{C} & 4.284018000 & -11.259309000 & 4.115122000\end{array}$




$\begin{array}{llll}\mathrm{H} & 4.062131000 & -9.666258000 & 0.387148000 \\ \mathrm{H} & 5.440232000 & -10.381560000 & -1.530287000 \\ \mathrm{H} & 3.325445000 & -9.937200000 & 2.742760000 \\ \mathrm{H} & 3.616996000 & -11.012746000 & 4.944403000 \\ \mathrm{H} & 4.853258000 & -12.608681000 & 6.394096000 \\ \mathrm{H} & 6.496803000 & -14.431354000 & 6.658240000 \\ \mathrm{H} & 8.185497000 & -15.951284000 & 5.715451000 \\ \mathrm{H} & 9.310726000 & -16.862129000 & 3.733052000 \\ \mathrm{H} & 9.677561000 & -16.857004000 & 1.271317000 \\ \mathrm{H} & 9.401547000 & -15.758625000 & -0.929310000 \\ \mathrm{H} & 8.557826000 & -13.855946000 & -2.291064000 \\ \mathrm{H} & 7.154373000 & -11.856648000 & -2.510391000\end{array}$

\section{Species E}

$\begin{array}{lccc}\text { Mo } & 9.169247000 & -11.070202000 & 2.855256000 \\ \text { O } & 8.638555000 & -12.748276000 & 3.516885000 \\ \text { O } & 9.789607000 & -9.424299000 & 1.576058000 \\ \text { O } & 8.239082000 & -11.372330000 & 1.191210000 \\ \text { O } & 10.831507000 & -11.142475000 & 3.154104000 \\ \text { C } & 11.303631000 & -11.122566000 & 7.035156000 \\ \text { C } & 11.316057000 & -10.000084000 & 7.765032000 \\ \text { H } & 12.200427000 & -9.357734000 & 7.808175000 \\ \text { H } & 10.616526000 & -8.907922000 & 5.913978000 \\ \text { H } & 10.453755000 & -9.700827000 & 8.367174000 \\ \text { O } & 10.239435000 & -8.329280000 & 5.229633000 \\ \text { H } & 11.105119000 & -8.171515000 & 3.833590000 \\ \text { H } & 9.433907000 & -8.799654000 & 4.936915000 \\ \text { O } & 11.527929000 & -8.241207000 & 2.929855000 \\ \text { H } & 12.087295000 & -9.028686000 & 3.004931000 \\ \text { O } & 8.447689000 & -9.980916000 & 3.937318000 \\ \text { C } & 10.114312000 & -12.040703000 & 7.000236000 \\ \text { H } & 9.264321000 & -11.636776000 & 7.566774000 \\ \text { H } & 9.786873000 & -12.237754000 & 5.967552000 \\ \text { H } & 10.382299000 & -13.019785000 & 7.431164000\end{array}$




$\begin{array}{llll}\text { C } & 12.483426000 & -11.557142000 & 6.212647000 \\ \text { H } & 12.200687000 & -11.631082000 & 5.150065000 \\ \text { H } & 13.330577000 & -10.863543000 & 6.308368000 \\ \text { H } & 12.820308000 & -12.559607000 & 6.523598000 \\ \text { H } & 9.093297000 & -8.942363000 & 1.113178000 \\ \text { H } & 10.472215000 & -8.802996000 & 2.042306000 \\ \text { C } & 7.644431000 & -13.617157000 & 0.789587000 \\ \text { C } & 7.101660000 & -12.206211000 & 0.861710000 \\ \text { C } & 6.098654000 & -12.027675000 & 1.985367000 \\ \text { C } & 6.293261000 & -12.708046000 & 3.153280000 \\ \text { C } & 7.499649000 & -13.617097000 & 3.269244000 \\ \text { C } & 7.837698000 & -14.308711000 & 1.966561000 \\ \text { C } & 5.505479000 & -12.422081000 & 4.317780000 \\ \text { C } & 5.732804000 & -13.144739000 & 5.484423000 \\ \text { C } & 6.650167000 & -14.208448000 & 5.532800000 \\ \text { C } & 7.429501000 & -14.560475000 & 4.451132000 \\ \text { C } & 8.183864000 & -15.756690000 & 4.393540000 \\ \text { C } & 8.711309000 & -16.226936000 & 3.220418000 \\ \text { C } & 8.515516000 & -15.551081000 & 1.977776000 \\ \text { C } & 8.964326000 & -16.075685000 & 0.745572000 \\ \text { C } & 8.769363000 & -15.387247000 & -0.430056000 \\ \text { C } & 8.114486000 & -14.135728000 & -0.440265000 \\ \text { C } & 7.897925000 & -13.389779000 & -1.638495000 \\ \text { C } & 7.166993000 & -12.231905000 & -1.651087000 \\ \text { C } & 6.598869000 & -11.692391000 & -0.472526000 \\ \text { C } & 5.632285000 & -10.709308000 & -0.482588000 \\ \text { C } & 4.916040000 & -10.349711000 & 0.672156000 \\ \text { C } & 5.094248000 & -11.007763000 & 1.885001000 \\ \text { C } & 4.303729000 & -10.731970000 & 3.046255000 \\ \text { C } & 4.501107000 & -11.407797000 & 4.210513000 \\ \text { H } & 4.145313000 & -9.578289000 & 0.601195000 \\ \text { H } & 5.365091000 & -10.246451000 & -1.436120000 \\ \text { H } & 3.535289000 & -9.958279000 & 2.979692000 \\ \text { H } & 3.894054000 & -11.182945000 & 5.090374000\end{array}$




$\begin{array}{llll}\mathrm{H} & 5.128547000 & -12.922729000 & 6.367041000 \\ \mathrm{H} & 6.697961000 & -14.824442000 & 6.434719000 \\ \mathrm{H} & 8.277923000 & -16.350378000 & 5.306407000 \\ \mathrm{H} & 9.250762000 & -17.176779000 & 3.211361000 \\ \mathrm{H} & 9.478699000 & -17.039293000 & 0.738688000 \\ \mathrm{H} & 9.128708000 & -15.801922000 & -1.374592000 \\ \mathrm{H} & 8.283270000 & -13.797210000 & -2.575942000 \\ \mathrm{H} & 6.946099000 & -11.740714000 & -2.602075000\end{array}$

\section{Species $\mathbf{F}$}

$\begin{array}{lccc}\text { Mo } & 9.171835000 & -11.074240000 & 2.864208000 \\ \text { O } & 8.628969000 & -12.743969000 & 3.523924000 \\ \text { O } & 9.784007000 & -9.425114000 & 1.570313000 \\ \text { O } & 8.230492000 & -11.363227000 & 1.204281000 \\ \text { O } & 10.835687000 & -11.146480000 & 3.135359000 \\ \text { H } & 10.631893000 & -8.901902000 & 5.893044000 \\ \text { O } & 10.234908000 & -8.327894000 & 5.225484000 \\ \text { H } & 11.142000000 & -8.178102000 & 3.814412000 \\ \text { H } & 9.449359000 & -8.826954000 & 4.912657000 \\ \text { O } & 11.559217000 & -8.263314000 & 2.915179000 \\ \text { H } & 12.085149000 & -9.074424000 & 2.986976000 \\ \text { O } & 8.477559000 & -9.968897000 & 3.952321000 \\ \text { H } & 9.085512000 & -8.943455000 & 1.110655000 \\ \text { H } & 10.470580000 & -8.807625000 & 2.020880000 \\ \text { C } & 7.645751000 & -13.610525000 & 0.794261000 \\ \text { C } & 7.098416000 & -12.201333000 & 0.867727000 \\ \text { C } & 6.090887000 & -12.028268000 & 1.988000000 \\ \text { C } & 6.284395000 & -12.709565000 & 3.155386000 \\ \text { C } & 7.492977000 & -13.615450000 & 3.272951000 \\ \text { C } & 7.836864000 & -14.304052000 & 1.970421000 \\ \text { C } & 5.491990000 & -12.428448000 & 4.317988000 \\ \text { C } & 5.718721000 & -13.151940000 & 5.483969000 \\ \text { C } & 6.640413000 & -14.211978000 & 5.533710000 \\ \text { C } & 7.423613000 & -14.559824000 & 4.453951000\end{array}$




$\begin{array}{llll}\text { C } & 8.183225000 & -15.752830000 & 4.397118000 \\ \text { C } & 8.714306000 & -16.220252000 & 3.224728000 \\ \text { C } & 8.518900000 & -15.543900000 & 1.982085000 \\ \text { C } & 8.973591000 & -16.064785000 & 0.750523000 \\ \text { C } & 8.780641000 & -15.374672000 & -0.424524000 \\ \text { C } & 8.122067000 & -14.125089000 & -0.434757000 \\ \text { C } & 7.907781000 & -13.377211000 & -1.632360000 \\ \text { C } & 7.173230000 & -12.221789000 & -1.645091000 \\ \text { C } & 6.598797000 & -11.686617000 & -0.467349000 \\ \text { C } & 5.628418000 & -10.707469000 & -0.479177000 \\ \text { C } & 4.906547000 & -10.352371000 & 0.673707000 \\ \text { C } & 5.083115000 & -11.011624000 & 1.885943000 \\ \text { C } & 4.287967000 & -10.740586000 & 3.045353000 \\ \text { C } & 4.484295000 & -11.417486000 & 4.209144000 \\ \text { H } & 4.133058000 & -9.583858000 & 0.601138000 \\ H & 5.362613000 & -10.244266000 & -1.432958000 \\ \text { H } & 3.516758000 & -9.969738000 & 2.977560000 \\ \text { H } & 3.873666000 & -11.196328000 & 5.087493000 \\ \text { H } & 5.111586000 & -12.933151000 & 6.365436000 \\ \text { H } & 6.689246000 & -14.827922000 & 6.435552000 \\ \text { H } & 8.278925000 & -16.346033000 & 5.310076000 \\ H & 9.258061000 & -17.167634000 & 3.216151000 \\ \text { H } & 9.491475000 & -17.026513000 & 0.743724000 \\ H & 9.144893000 & -15.786362000 & -1.368491000 \\ \text { H } & 8.297992000 & -13.781443000 & -2.569181000 \\ \text { H } & 6.954144000 & -11.729274000 & -2.595835000\end{array}$

\section{Transition state 2' (TS2') non-water assisted pathway}

$\begin{array}{lrrr}\text { C } & 0.218911000 & -1.222189000 & -1.360065000 \\ \text { C } & -0.665828000 & -0.072643000 & -0.924210000 \\ \text { C } & -2.067385000 & -0.519087000 & -0.561254000 \\ \text { C } & -2.211812000 & -1.732329000 & 0.075279000 \\ \text { C } & -0.963298000 & -2.540368000 & 0.370465000 \\ \text { C } & 0.072756000 & -2.422507000 & -0.729442000\end{array}$




$\begin{array}{lrrr}\text { C } & -3.459382000 & -2.118976000 & 0.618908000 \\ \text { C } & -3.568243000 & -3.378873000 & 1.282492000 \\ \text { C } & -2.526675000 & -4.266952000 & 1.328044000 \\ \text { C } & -1.273219000 & -3.981703000 & 0.734839000 \\ \text { C } & -0.319380000 & -4.948533000 & 0.496504000 \\ \text { C } & 0.811698000 & -4.705190000 & -0.302172000 \\ \text { C } & 1.007442000 & -3.489286000 & -0.949022000 \\ \text { C } & 2.092834000 & -3.251205000 & -1.852406000 \\ \text { C } & 2.240961000 & -2.050134000 & -2.475929000 \\ \text { C } & 1.315388000 & -0.980520000 & -2.253017000 \\ \text { C } & 1.426592000 & 0.261398000 & -2.869660000 \\ \text { C } & 0.448816000 & 1.259158000 & -2.711580000 \\ \text { C } & -0.646886000 & 1.095634000 & -1.891015000 \\ \text { C } & -1.758781000 & 1.971796000 & -1.901180000 \\ \text { C } & -2.952833000 & 1.636763000 & -1.320096000 \\ \text { C } & -3.155829000 & 0.375664000 & -0.681610000 \\ \text { C } & -4.406481000 & -0.024478000 & -0.160412000 \\ \text { C } & -4.553864000 & -1.237731000 & 0.471505000 \\ \text { Mo } & 0.067052000 & -0.111196000 & 2.116043000 \\ \text { O } & -0.079629000 & 0.404892000 & 0.297908000 \\ \text { O } & -0.364547000 & -1.971776000 & 1.543745000 \\ \text { O } & 0.473130000 & -1.288329000 & 3.709458000 \\ \text { O } & -1.172822000 & 0.757092000 & 2.826499000 \\ \text { H } & 3.075586000 & -1.881280000 & -3.160689000 \\ \text { H } & 2.806302000 & -4.059241000 & -2.032363000 \\ \text { H } & 1.523190000 & -5.515955000 & -0.478612000 \\ \text { H } & -0.488637000 & -5.958426000 & 0.879844000 \\ \text { H } & -2.678457000 & -5.258158000 & 1.763390000 \\ \text { H } & -4.534323000 & -3.653481000 & 1.712743000 \\ \text { H } & -5.523957000 & -1.528674000 & 0.880929000 \\ \text { H } & -5.258354000 & 0.653262000 & -0.253676000 \\ \text { H } & -3.799811000 & 2.323871000 & -1.386711000 \\ \text { H } & -1.671746000 & 2.908696000 & -2.457629000 \\ \text { H } & 0.518668000 & 2.167704000 & -3.315933000\end{array}$




$\begin{array}{llll}\mathrm{H} & 2.263527000 & 0.439086000 & -3.549594000 \\ \mathrm{O} & 1.574439000 & 0.668657000 & 2.455319000 \\ \mathrm{C} & 3.068519000 & 0.615107000 & 4.015022000 \\ \mathrm{C} & 4.150234000 & 0.637433000 & 2.992317000 \\ \mathrm{H} & 4.002801000 & 1.439454000 & 2.260475000 \\ \mathrm{H} & 4.233159000 & -0.325755000 & 2.473688000 \\ \mathrm{H} & 5.098402000 & 0.815569000 & 3.530914000 \\ \mathrm{C} & 2.599029000 & 1.921216000 & 4.557107000 \\ \mathrm{H} & 2.517071000 & 2.680615000 & 3.771339000 \\ \mathrm{H} & 1.634532000 & 1.818476000 & 5.070566000 \\ \mathrm{H} & 3.346918000 & 2.254192000 & 5.298862000 \\ \mathrm{C} & 2.789641000 & -0.576300000 & 4.723102000 \\ \mathrm{H} & 1.715434000 & -0.988878000 & 4.226528000 \\ \mathrm{H} & 3.499888000 & -1.397904000 & 4.570704000 \\ \mathrm{H} & 2.464946000 & -0.437338000 & 5.761628000 \\ \mathrm{H} & 0.285882000 & -2.210127000 & 3.471042000\end{array}$

\section{Species D' (non-water-assisted pathway)}

$\begin{array}{lrrr}\text { C } & 0.407792000 & -1.129566000 & -1.025681000 \\ \text { C } & -0.574695000 & -0.010500000 & -0.757385000 \\ \text { C } & -1.982097000 & -0.516093000 & -0.513252000 \\ \text { C } & -2.144403000 & -1.721037000 & 0.141442000 \\ \text { C } & -0.909001000 & -2.477596000 & 0.590244000 \\ \text { C } & 0.247594000 & -2.317520000 & -0.372673000 \\ \text { C } & -3.425396000 & -2.147260000 & 0.563303000 \\ \text { C } & -3.556377000 & -3.400450000 & 1.241524000 \\ \text { C } & -2.495615000 & -4.246414000 & 1.411509000 \\ \text { C } & -1.194431000 & -3.920678000 & 0.949680000 \\ \text { C } & -0.176159000 & -4.841541000 & 0.848414000 \\ \text { C } & 1.037269000 & -4.552781000 & 0.194607000 \\ \text { C } & 1.254162000 & -3.341016000 & -0.447929000 \\ \text { C } & 2.431192000 & -3.068142000 & -1.218660000 \\ \text { C } & 2.591641000 & -1.882138000 & -1.863898000 \\ \text { C } & 1.588937000 & -0.860910000 & -1.798155000\end{array}$




$\begin{array}{lrrr}\text { C } & 1.703577000 & 0.354084000 & -2.459837000 \\ \text { C } & 0.661445000 & 1.301419000 & -2.468323000 \\ \text { C } & -0.508034000 & 1.113167000 & -1.768581000 \\ \text { C } & -1.651054000 & 1.938171000 & -1.922585000 \\ \text { C } & -2.877039000 & 1.571682000 & -1.441533000 \\ \text { C } & -3.088726000 & 0.323633000 & -0.774362000 \\ \text { C } & -4.367119000 & -0.114096000 & -0.368084000 \\ \text { C } & -4.530784000 & -1.316293000 & 0.281929000 \\ \text { Mo } & -0.445121000 & 0.050979000 & 2.276907000 \\ \text { O } & -0.114766000 & 0.559974000 & 0.500156000 \\ \text { O } & -0.471659000 & -1.850925000 & 1.828969000 \\ \text { O } & -0.578514000 & -1.198015000 & 4.206440000 \\ \text { O } & -1.896227000 & 0.775674000 & 2.697399000 \\ \text { H } & 3.493625000 & -1.687327000 & -2.448496000 \\ \text { H } & 3.201997000 & -3.840126000 & -1.279897000 \\ \text { H } & 1.803174000 & -5.329331000 & 0.127911000 \\ \text { H } & -0.343596000 & -5.852888000 & 1.228352000 \\ \text { H } & -2.654654000 & -5.235044000 & 1.849732000 \\ \text { H } & -4.551345000 & -3.702921000 & 1.575833000 \\ \text { H } & -5.525505000 & -1.636535000 & 0.599597000 \\ \text { H } & -5.231096000 & 0.523919000 & -0.566901000 \\ \text { H } & -3.741997000 & 2.216633000 & -1.612378000 \\ \text { H } & -1.547857000 & 2.858669000 & -2.502519000 \\ \text { H } & 0.756872000 & 2.186300000 & -3.102961000 \\ \text { H } & 2.604692000 & 0.551383000 & -3.045306000 \\ \text { O } & 0.822458000 & 0.758204000 & 3.129901000 \\ \text { H } & -0.488630000 & -2.089617000 & 3.823401000 \\ \text { H } & 0.187655000 & -1.031409000 & 4.775065000\end{array}$

\section{Mo $=\mathbf{O}$ assisted $\boldsymbol{\beta}-\mathrm{H}$ transfer intermediate (higher barrier)}

$\begin{array}{lrrr}\text { C } & 0.486916000 & -1.067288000 & -0.983960000 \\ \text { C } & -0.525455000 & 0.035067000 & -0.753512000 \\ \text { C } & -1.941854000 & -0.492956000 & -0.638859000 \\ \text { C } & -2.135030000 & -1.698654000 & -0.000500000\end{array}$




$\begin{array}{lrrr}\text { C } & -0.912645000 & -2.411479000 & 0.540811000 \\ \text { C } & 0.293483000 & -2.267681000 & -0.365494000 \\ \text { C } & -3.433469000 & -2.149166000 & 0.330523000 \\ \text { C } & -3.581921000 & -3.384648000 & 1.032489000 \\ \text { C } & -2.513160000 & -4.191730000 & 1.317523000 \\ \text { C } & -1.192717000 & -3.847639000 & 0.939696000 \\ \text { C } & -0.157315000 & -4.757402000 & 0.914907000 \\ \text { C } & 1.075033000 & -4.475014000 & 0.299755000 \\ \text { C } & 1.309592000 & -3.278270000 & -0.369585000 \\ \text { C } & 2.525128000 & -2.998674000 & -1.072656000 \\ \text { C } & 2.718082000 & -1.804272000 & -1.696288000 \\ \text { C } & 1.712549000 & -0.784507000 & -1.674889000 \\ \text { C } & 1.863724000 & 0.442653000 & -2.312474000 \\ \text { C } & 0.814686000 & 1.376297000 & -2.375601000 \\ \text { C } & -0.401509000 & 1.164348000 & -1.759709000 \\ \text { C } & -1.542473000 & 1.964093000 & -2.013019000 \\ \text { C } & -2.801388000 & 1.573066000 & -1.641952000 \\ \text { C } & -3.041902000 & 0.323676000 & -0.993134000 \\ \text { C } & -4.341528000 & -0.144823000 & -0.694216000 \\ \text { C } & -4.532142000 & -1.345642000 & -0.048845000 \\ \text { Mo } & -0.212195000 & 0.083575000 & 2.383436000 \\ \text { O } & -0.220848000 & 0.628330000 & 0.523513000 \\ \text { O } & -0.542562000 & -1.701935000 & 1.719919000 \\ \text { O } & 1.462059000 & 0.043290000 & 2.855932000 \\ \text { O } & -1.307121000 & -0.506684000 & 3.826784000 \\ \text { H } & -1.589859000 & 0.185057000 & 4.437925000 \\ \text { H } & 3.652017000 & -1.601744000 & -2.225889000 \\ \text { H } & 3.303608000 & -3.765345000 & -1.092250000 \\ \text { H } & 1.853718000 & -5.241991000 & 0.294476000 \\ \text { H } & -0.327397000 & -5.757304000 & 1.322621000 \\ \text { H } & -2.679870000 & -5.168669000 & 1.778284000 \\ \text { H } & -4.590781000 & -3.707629000 & 1.300039000 \\ \text { H } & -5.542367000 & -1.686411000 & 0.189780000 \\ \text { H } & -5.200450000 & 0.470024000 & -0.973609000\end{array}$




$\begin{array}{lrrr}\mathrm{H} & -3.661312000 & 2.197102000 & -1.896975000 \\ \mathrm{H} & -1.409766000 & 2.882176000 & -2.592045000 \\ \mathrm{H} & 0.937135000 & 2.266815000 & -2.998838000 \\ \mathrm{H} & 2.796862000 & 0.651364000 & -2.841334000 \\ \mathrm{O} & -0.541432000 & 1.731408000 & 2.773438000 \\ \mathrm{C} & 1.136916000 & 3.255688000 & 3.009808000 \\ \mathrm{C} & 0.863278000 & 3.727966000 & 1.622500000 \\ \mathrm{H} & -0.191093000 & 3.991700000 & 1.483970000 \\ \mathrm{H} & 1.137173000 & 2.967991000 & 0.878768000 \\ \mathrm{H} & 1.482252000 & 4.626346000 & 1.449994000 \\ \mathrm{C} & 0.385518000 & 3.891926000 & 4.128435000 \\ \mathrm{H} & -0.670241000 & 4.037598000 & 3.874891000 \\ \mathrm{H} & 0.471282000 & 3.312538000 & 5.056555000 \\ \mathrm{H} & 0.842583000 & 4.881943000 & 4.305360000 \\ \mathrm{C} & 2.277800000 & 2.482087000 & 3.274733000 \\ \mathrm{H} & 1.890543000 & 1.276119000 & 3.128737000 \\ \mathrm{H} & 3.047739000 & 2.474189000 & 2.493499000 \\ \mathrm{H} & 2.654627000 & 2.491769000 & 4.303708000\end{array}$

\section{$\mathrm{AC} / \mathrm{Mo}(\mathrm{OH})_{2}$}

$\begin{array}{lrrr}\text { C } & 0.627720000 & -0.992790000 & -0.693671000 \\ \text { C } & -0.390799000 & 0.102105000 & -0.478243000 \\ \text { C } & -1.814678000 & -0.401771000 & -0.486232000 \\ \text { C } & -2.070753000 & -1.654657000 & 0.028303000 \\ \text { C } & -0.903861000 & -2.425426000 & 0.610632000 \\ \text { C } & 0.375554000 & -2.231916000 & -0.178752000 \\ \text { C } & -3.394687000 & -2.108289000 & 0.220524000 \\ \text { C } & -3.608659000 & -3.390040000 & 0.813636000 \\ \text { C } & -2.574393000 & -4.231302000 & 1.129007000 \\ \text { C } & -1.224483000 & -3.880013000 & 0.889331000 \\ \text { C } & -0.195539000 & -4.798094000 & 0.887143000 \\ \text { C } & 1.083671000 & -4.487794000 & 0.394999000 \\ \text { C } & 1.381314000 & -3.251245000 & -0.170518000\end{array}$




$\begin{array}{llll}\text { C } & 2.651380000 & -2.938318000 & -0.751474000 \\ \text { C } & 2.902257000 & -1.706095000 & -1.273177000 \\ \text { C } & 1.906764000 & -0.676980000 & -1.261490000 \\ \text { C } & 2.118783000 & 0.590731000 & -1.795964000 \\ \text { C } & 1.086504000 & 1.538311000 & -1.874718000 \\ \text { C } & -0.177737000 & 1.300717000 & -1.374261000 \\ \text { C } & -1.285645000 & 2.140102000 & -1.642072000 \\ \text { C } & -2.573136000 & 1.750053000 & -1.386319000 \\ \text { C } & -2.875200000 & 0.459498000 & -0.855931000 \\ \text { C } & -4.199010000 & -0.011226000 & -0.698897000 \\ \text { C } & -4.451946000 & -1.258225000 & -0.175151000 \\ \text { Mo } & -0.099182000 & -0.068578000 & 2.611400000 \\ \text { O } & -0.141646000 & 0.628020000 & 0.879136000 \\ \text { O } & -0.644527000 & -1.767662000 & 1.849005000 \\ \text { O } & 1.411177000 & -0.990479000 & 3.236130000 \\ \text { O } & -1.667435000 & -0.112556000 & 3.630684000 \\ \text { H } & -1.819377000 & 0.640652000 & 4.219412000 \\ \text { H } & 3.877301000 & -1.479041000 & -1.710136000 \\ \text { H } & 3.424314000 & -3.710502000 & -0.760939000 \\ \text { H } & 1.855618000 & -5.261387000 & 0.400565000 \\ \text { H } & -0.403853000 & -5.821483000 & 1.209508000 \\ \text { H } & -2.788395000 & -5.235729000 & 1.502671000 \\ \text { H } & -4.638663000 & -3.717893000 & 0.973233000 \\ \text { H } & -5.481200000 & -1.600816000 & -0.045265000 \\ \text { H } & -5.026676000 & 0.638584000 & -0.992395000 \\ \text { H } & -3.403276000 & 2.409890000 & -1.648614000 \\ \text { H } & -1.096998000 & 3.097663000 & -2.134017000 \\ \text { H } & 1.266432000 & 2.473229000 & -2.411859000 \\ \text { H } & 3.093558000 & 0.824874000 & -2.229588000 \\ \text { O } & 0.431055000 & 1.404459000 & 3.238551000 \\ \text { H } & 2.053777000 & -0.452487000 & 3.720650000\end{array}$

\section{TS2-0xo}

$\begin{array}{llll}\text { C } & 0.486916000 & -1.067288000 & -0.983960000\end{array}$ 


$\begin{array}{lrrr}\text { C } & -0.525455000 & 0.035067000 & -0.753512000 \\ \text { C } & -1.941854000 & -0.492956000 & -0.638859000 \\ \text { C } & -2.135030000 & -1.698654000 & -0.000500000 \\ \text { C } & -0.912645000 & -2.411479000 & 0.540811000 \\ \text { C } & 0.293483000 & -2.267681000 & -0.365494000 \\ \text { C } & -3.433469000 & -2.149166000 & 0.330523000 \\ \text { C } & -3.581921000 & -3.384648000 & 1.032489000 \\ \text { C } & -2.513160000 & -4.191730000 & 1.317523000 \\ \text { C } & -1.192717000 & -3.847639000 & 0.939696000 \\ \text { C } & -0.157315000 & -4.757402000 & 0.914907000 \\ \text { C } & 1.075033000 & -4.475014000 & 0.299755000 \\ \text { C } & 1.309592000 & -3.278270000 & -0.369585000 \\ \text { C } & 2.525128000 & -2.998674000 & -1.072656000 \\ \text { C } & 2.718082000 & -1.804272000 & -1.696288000 \\ \text { C } & 1.712549000 & -0.784507000 & -1.674889000 \\ \text { C } & 1.863724000 & 0.442653000 & -2.312474000 \\ \text { C } & 0.814686000 & 1.376297000 & -2.375601000 \\ \text { C } & -0.401509000 & 1.164348000 & -1.759709000 \\ \text { C } & -1.542473000 & 1.964093000 & -2.013019000 \\ \text { C } & -2.801388000 & 1.573066000 & -1.641952000 \\ \text { C } & -3.041902000 & 0.323676000 & -0.993134000 \\ \text { C } & -4.341528000 & -0.144823000 & -0.694216000 \\ \text { C } & -4.532142000 & -1.345642000 & -0.048845000 \\ \text { Mo } & -0.212195000 & 0.083575000 & 2.383436000 \\ \text { O } & -0.220848000 & 0.628330000 & 0.523513000 \\ \text { O } & -0.542562000 & -1.701935000 & 1.719919000 \\ \text { O } & 1.462059000 & 0.043290000 & 2.855932000 \\ \text { O } & -1.307121000 & -0.506684000 & 3.826784000 \\ \text { H } & -1.589859000 & 0.185057000 & 4.437925000 \\ \text { H } & 3.652017000 & -1.601744000 & -2.225889000 \\ \text { H } & 3.303608000 & -3.765345000 & -1.092250000 \\ \text { H } & 1.853718000 & -5.241991000 & 0.294476000 \\ \text { H } & -0.327397000 & -5.757304000 & 1.322621000 \\ \text { H } & -2.679870000 & -5.168669000 & 1.778284000\end{array}$




$\begin{array}{lrrr}\mathrm{H} & -4.590781000 & -3.707629000 & 1.300039000 \\ \mathrm{H} & -5.542367000 & -1.686411000 & 0.189780000 \\ \mathrm{H} & -5.200450000 & 0.470024000 & -0.973609000 \\ \mathrm{H} & -3.661312000 & 2.197102000 & -1.896975000 \\ \mathrm{H} & -1.409766000 & 2.882176000 & -2.592045000 \\ \mathrm{H} & 0.937135000 & 2.266815000 & -2.998838000 \\ \mathrm{H} & 2.796862000 & 0.651364000 & -2.841334000 \\ \mathrm{O} & -0.541432000 & 1.731408000 & 2.773438000 \\ \mathrm{C} & 1.136916000 & 3.255688000 & 3.009808000 \\ \mathrm{C} & 0.863278000 & 3.727966000 & 1.622500000 \\ \mathrm{H} & -0.191093000 & 3.991700000 & 1.483970000 \\ \mathrm{H} & 1.137173000 & 2.967991000 & 0.878768000 \\ \mathrm{H} & 1.482252000 & 4.626346000 & 1.449994000 \\ \mathrm{C} & 0.385518000 & 3.891926000 & 4.128435000 \\ \mathrm{H} & -0.670241000 & 4.037598000 & 3.874891000 \\ \mathrm{H} & 0.471282000 & 3.312538000 & 5.056555000 \\ \mathrm{H} & 0.842583000 & 4.881943000 & 4.305360000 \\ \mathrm{C} & 2.277800000 & 2.482087000 & 3.274733000 \\ \mathrm{H} & 1.890543000 & 1.276119000 & 3.128737000 \\ \mathrm{H} & 3.047739000 & 2.474189000 & 2.493499000 \\ \mathrm{H} & 2.654627000 & 2.491769000 & 4.303708000\end{array}$

\section{${ }^{1} \mathrm{H}$-NMR of Reactions in Table 1}

The following figures list the ${ }^{1} \mathrm{H}-\mathrm{NMR}\left(\mathrm{DCM}-\mathrm{d}_{2}\right.$ or DMSO- $\mathrm{d}_{6}$ ) before (red) and after (turquoise) the reaction given in Table 1. In a typical analysis, conversion and yield are calculated by the following equations where [substrate] and [product] is the peak area of the specified substrate and product in ${ }^{1} \mathrm{H}-\mathrm{NMR}$ against the internal standard (mesitylene $\delta 6.75 \mathrm{ppm}, 2.21 \mathrm{ppm}$ ) at each respective time point, other products were identified in a similar fashion.

$$
\begin{gathered}
\text { conversion }=\frac{[\text { substrate }]_{t 0}-[\text { substrate }]_{t}}{[\text { substrate }]_{t 0}} \times 100 \% \\
\text { yield }=\frac{[\text { product }]_{t}}{[\text { substrate }]_{t 0}} \times 100 \%
\end{gathered}
$$



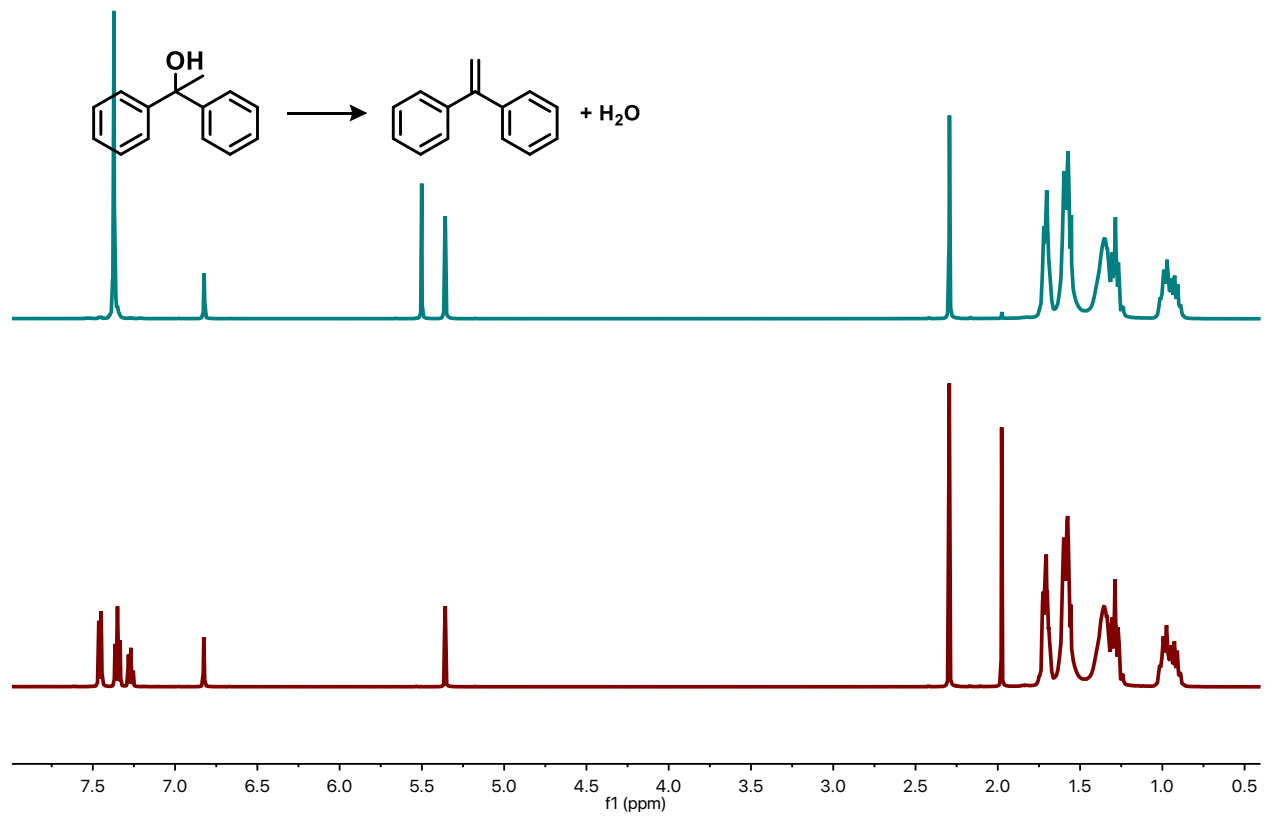

Figure S18. ${ }^{1} \mathrm{H}$ NMR (500 MHz in DCM- $\left.\mathrm{d}_{2}\right)$ before (red) and after (turquoise) the conversion of diphenyl-ethanol (Table 1, Entry 1).

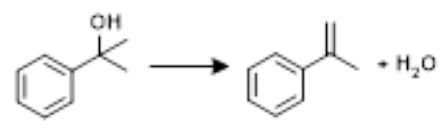

S43 

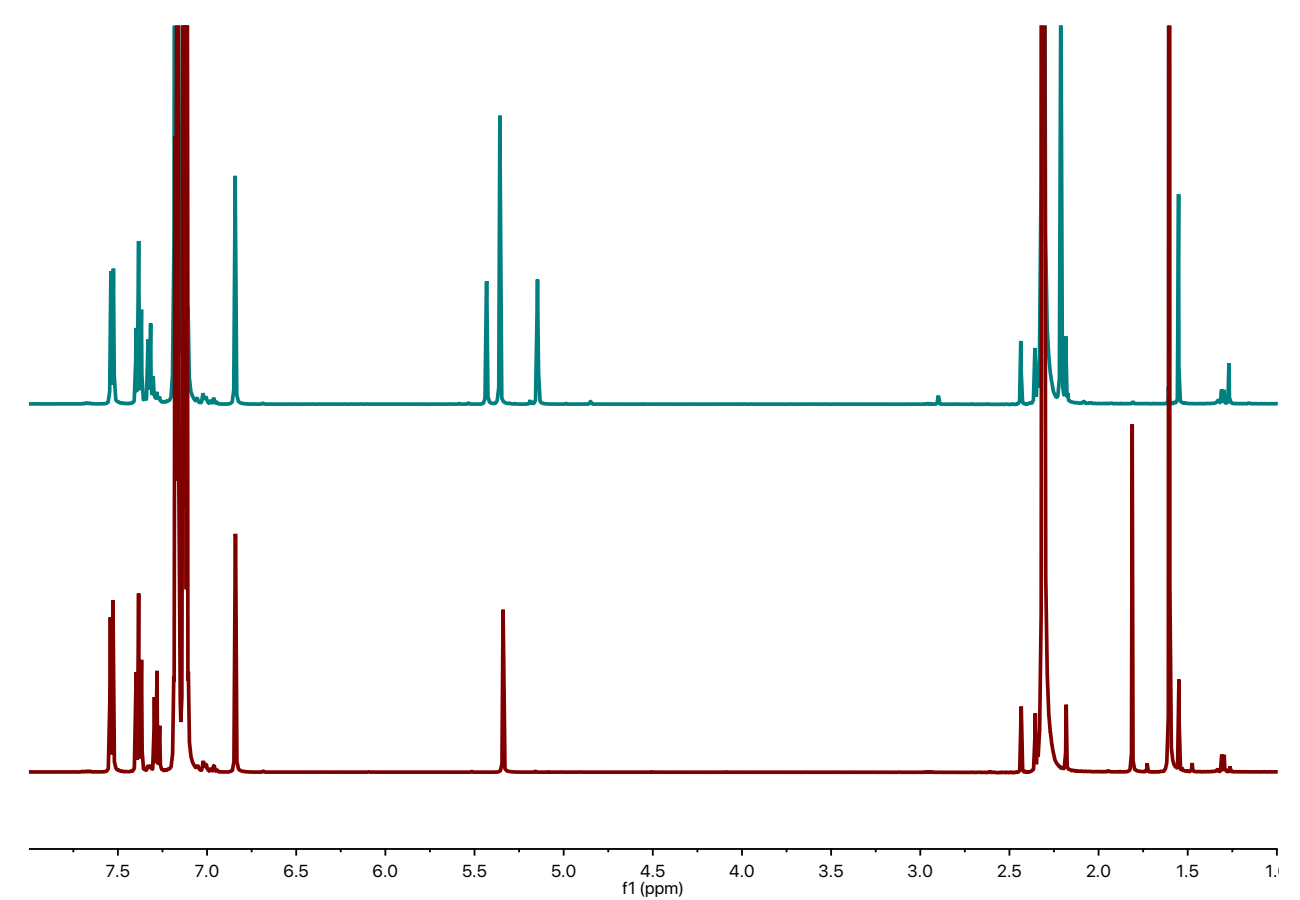

Figure S19. ${ }^{1} \mathrm{H}$ NMR (500 MHz in DCM- $\mathrm{d}_{2}$ ) before (red) and after (turquoise) the conversion of dimethyl-phenyl-alcohol (Table 1, Entry 3).

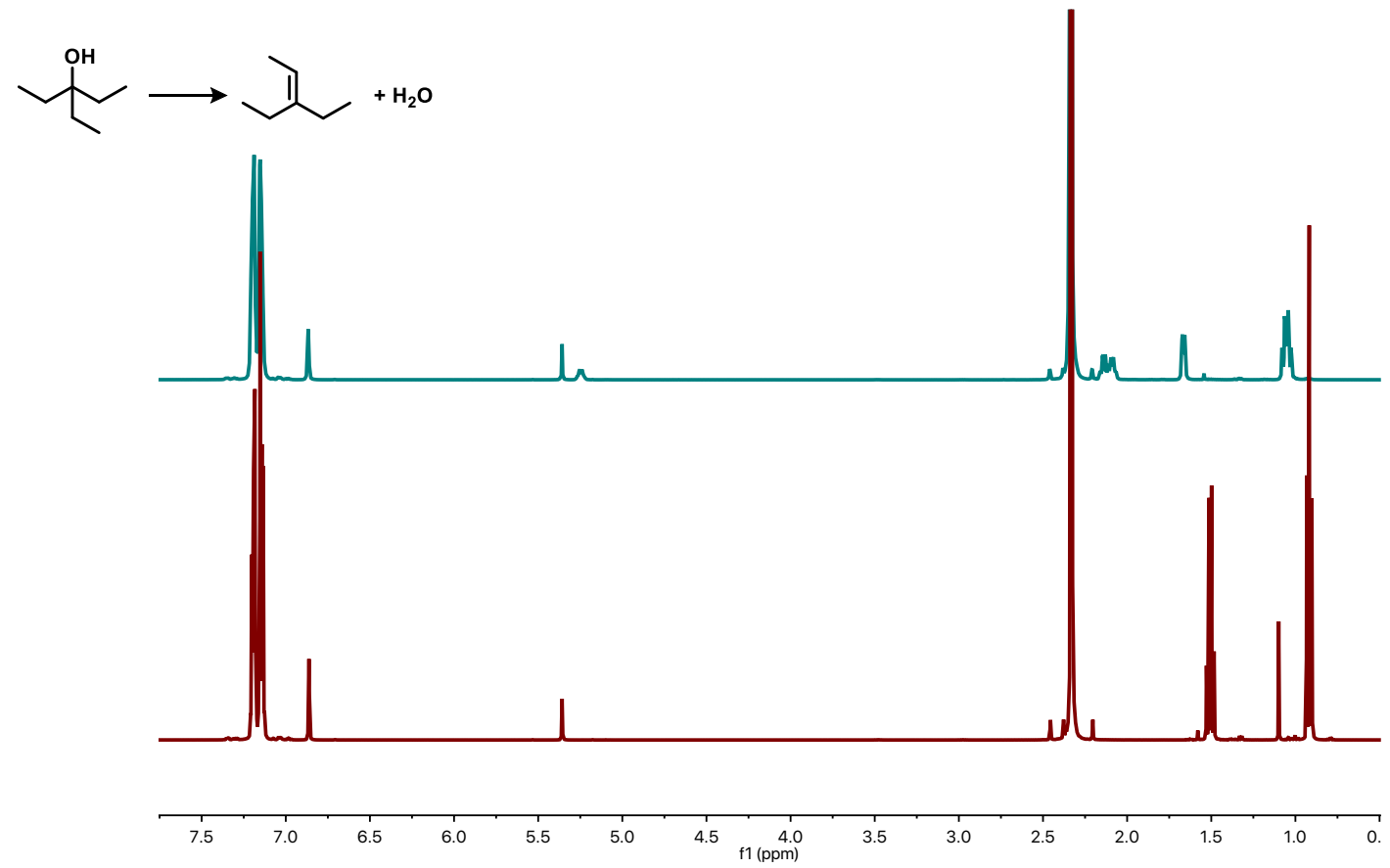

Figure S20. ${ }^{1} \mathrm{H}$ NMR (500 MHz in DCM- $\mathrm{d}_{2}$ ) before (red) and after (turquoise) the conversion of 3-ethyl-pentanol (Table 1, Entry 6). 


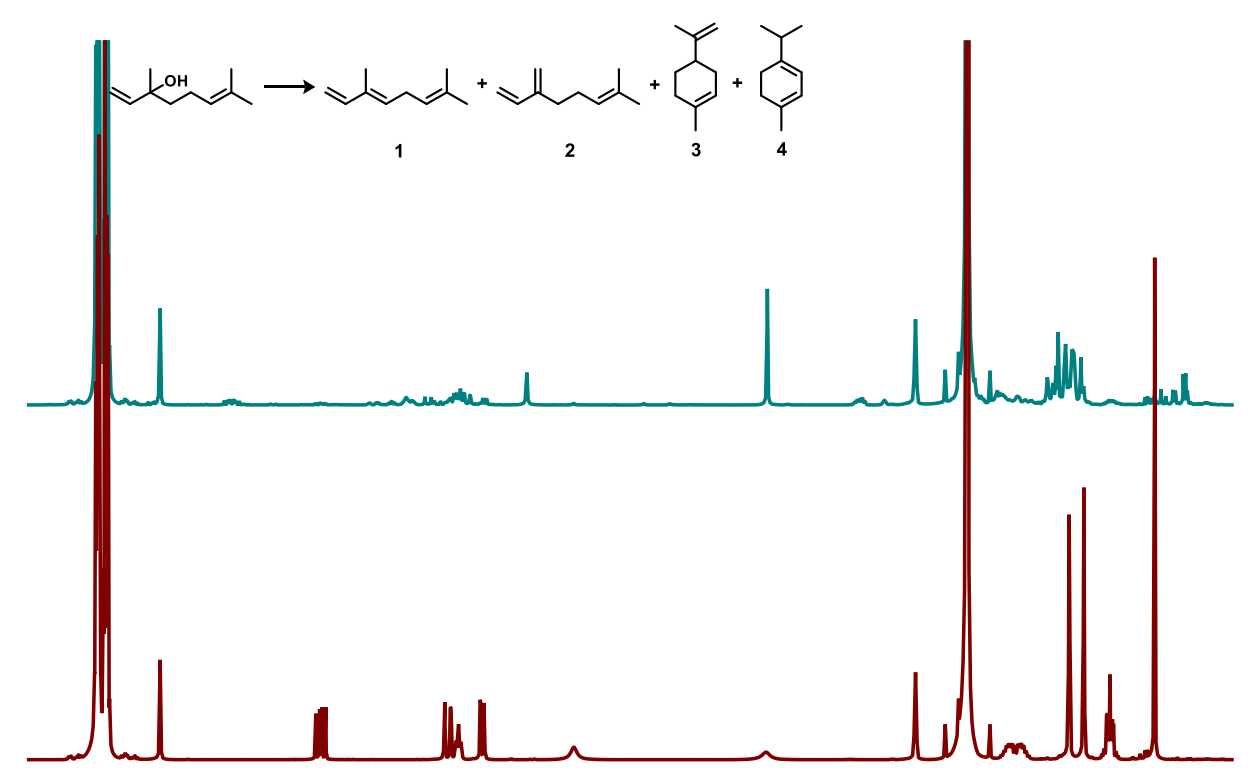

\begin{tabular}{llllllllllllllllllllllllllllllllllllllllllllll}
\hline 7.4 & 7.2 & 7.0 & 6.8 & 6.6 & 6.4 & 6.2 & 6.0 & 5.8 & 5.6 & 5.4 & 5.2 & 5.0 & 4.8 & 4.6 & 4.4 & 4.2 & 4.0 & 3.8 & 3.6 & 3.4 & 3.2 & 3.0 & 2.8 & 2.6 & 2.4 & 2.2 & 2.0 & 1.8 & 1.6 & 1.4 & 1.2 & 1.0 & 0.8
\end{tabular}

Figure S21. ${ }^{1} \mathrm{H}$ NMR $\left(500 \mathrm{MHz}\right.$ in DMSO- $\mathrm{d}_{6}$ ) before (red) and after (turquoise) the conversion of linalool (Table 1, Entry 8).

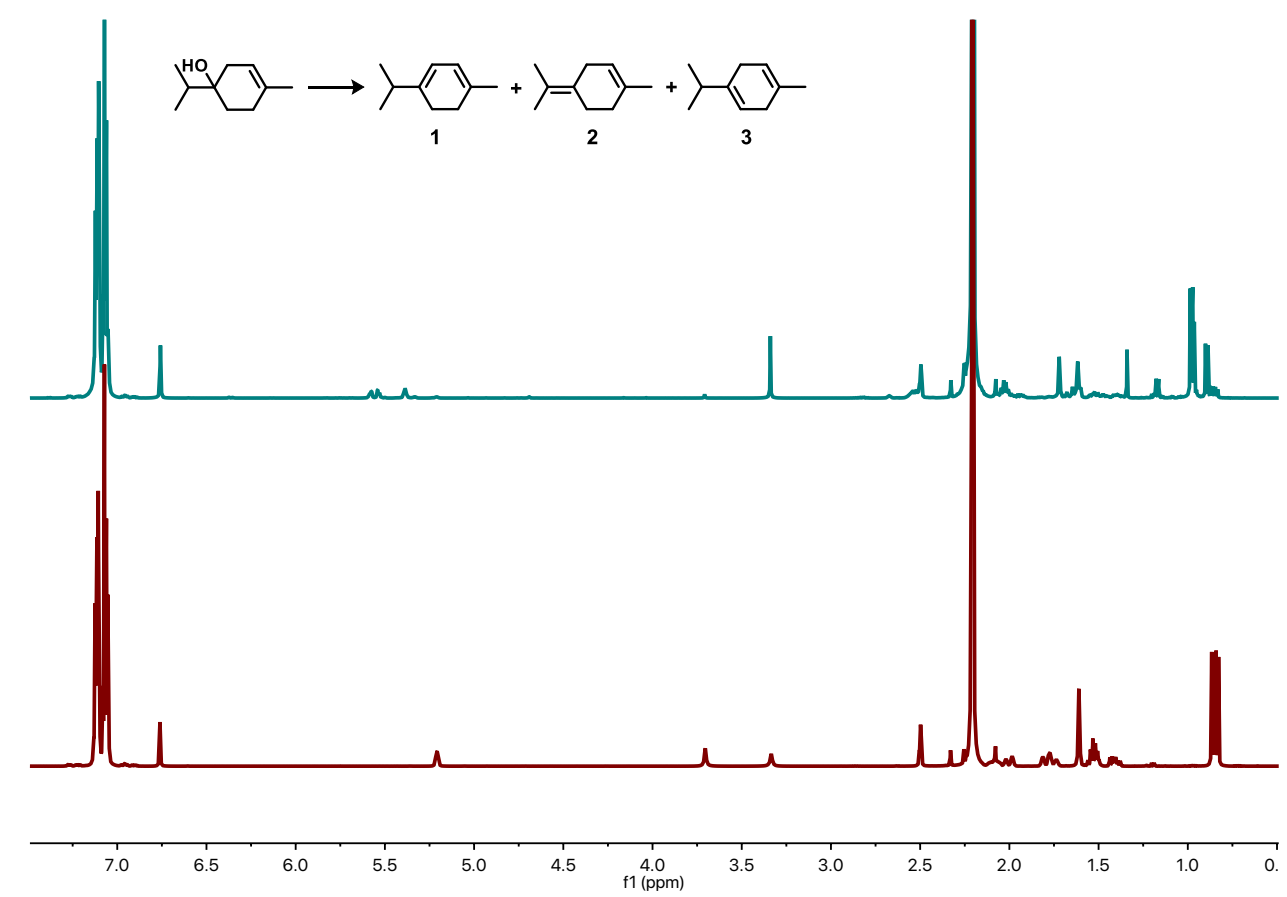

Figure S22. ${ }^{1} \mathrm{H}$ NMR (500 MHz in DMSO- $\mathrm{d}_{6}$ ) before (red) and after (turquoise) the conversion of terpineol (Table 1, Entry 9). 

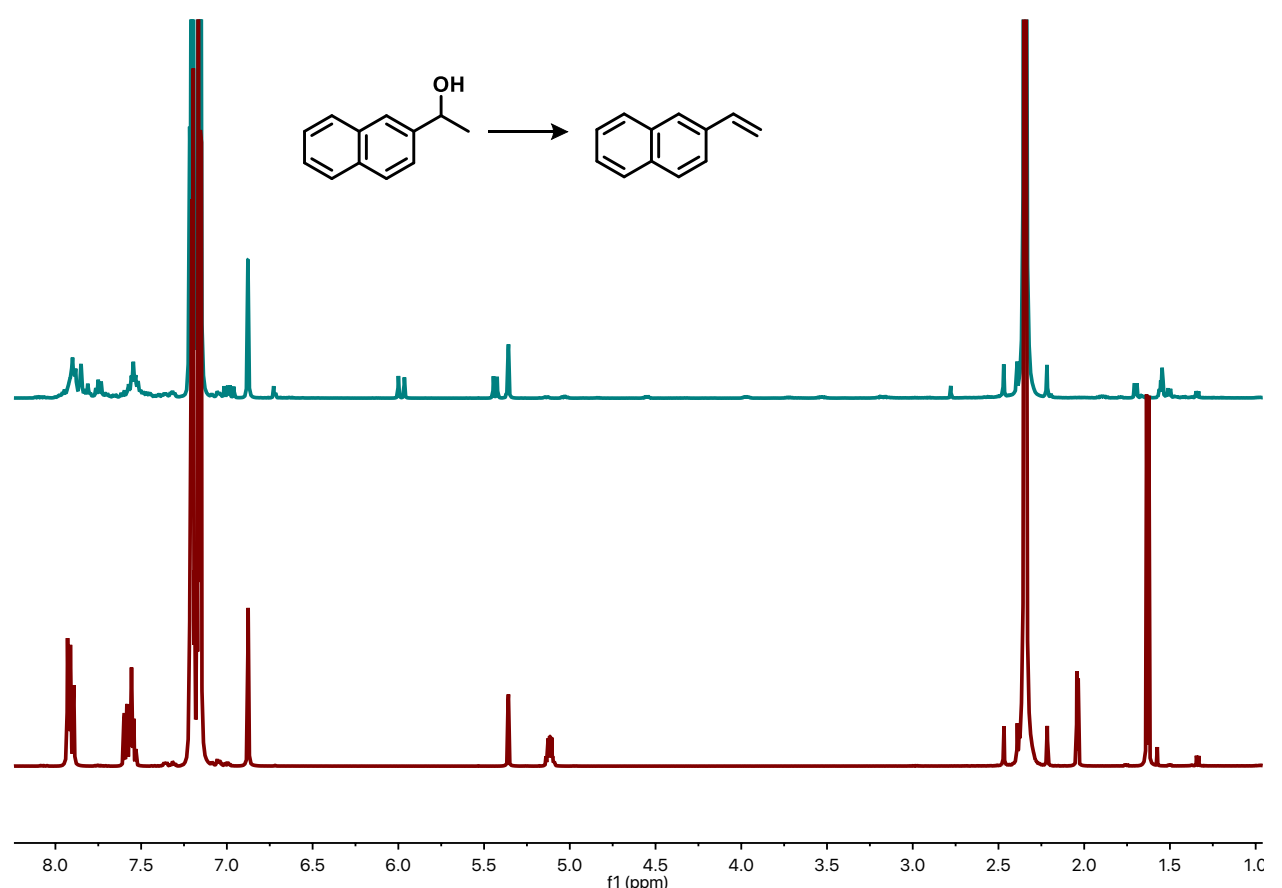

Figure S23. ${ }^{1} \mathrm{H}$ NMR (500 MHz in DCM- $\left.\mathrm{d}_{2}\right)$ before (red) and after (turquoise) the conversion of a-methyl-2-naphthalenemethanol (Table 1, Entry 10).

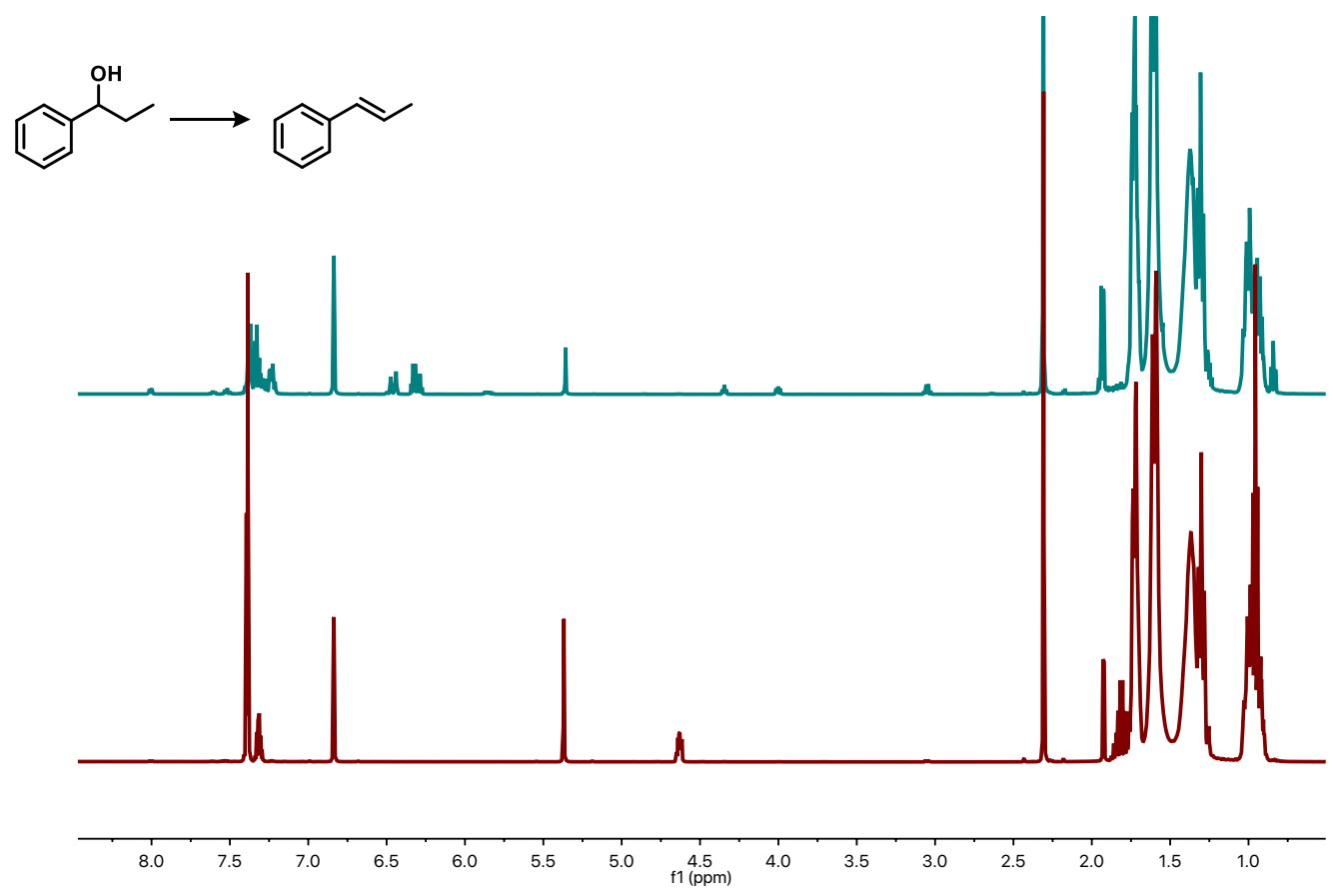

Figure S24. ${ }^{1} \mathrm{H}$ NMR (500 MHz in DCM- $\mathrm{d}_{2}$ ) before (red) and after (turquoise) the conversion of 1-phenyl-1-propanol (Table 1, Entry 11). 


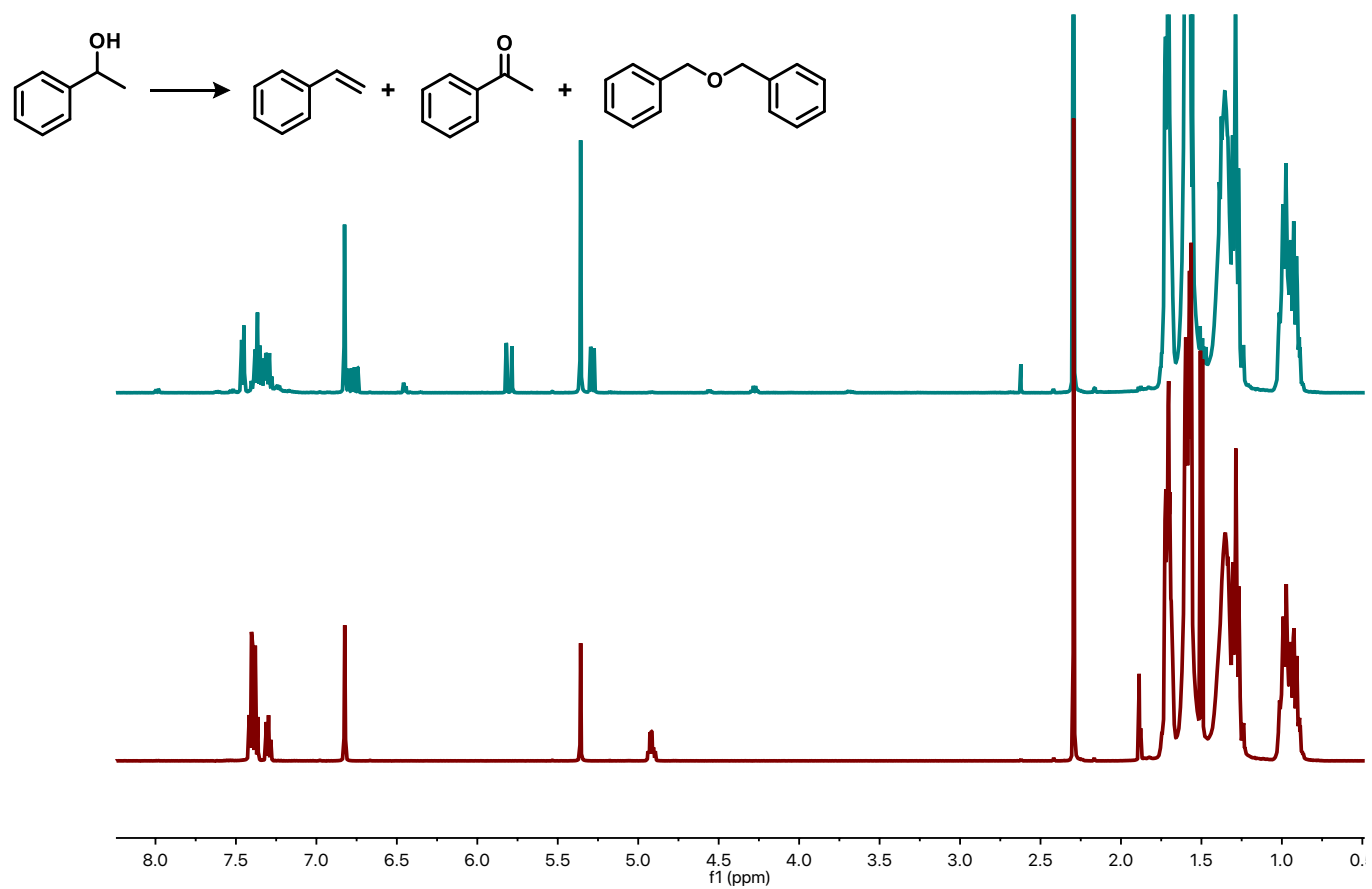

Figure S25. ${ }^{1} \mathrm{H}$ NMR (500 MHz in DCM- $\mathrm{d}_{2}$ ) before (red) and after (turquoise) the conversion of 1-phenyl-ethanol (Table 1, Entry 12).
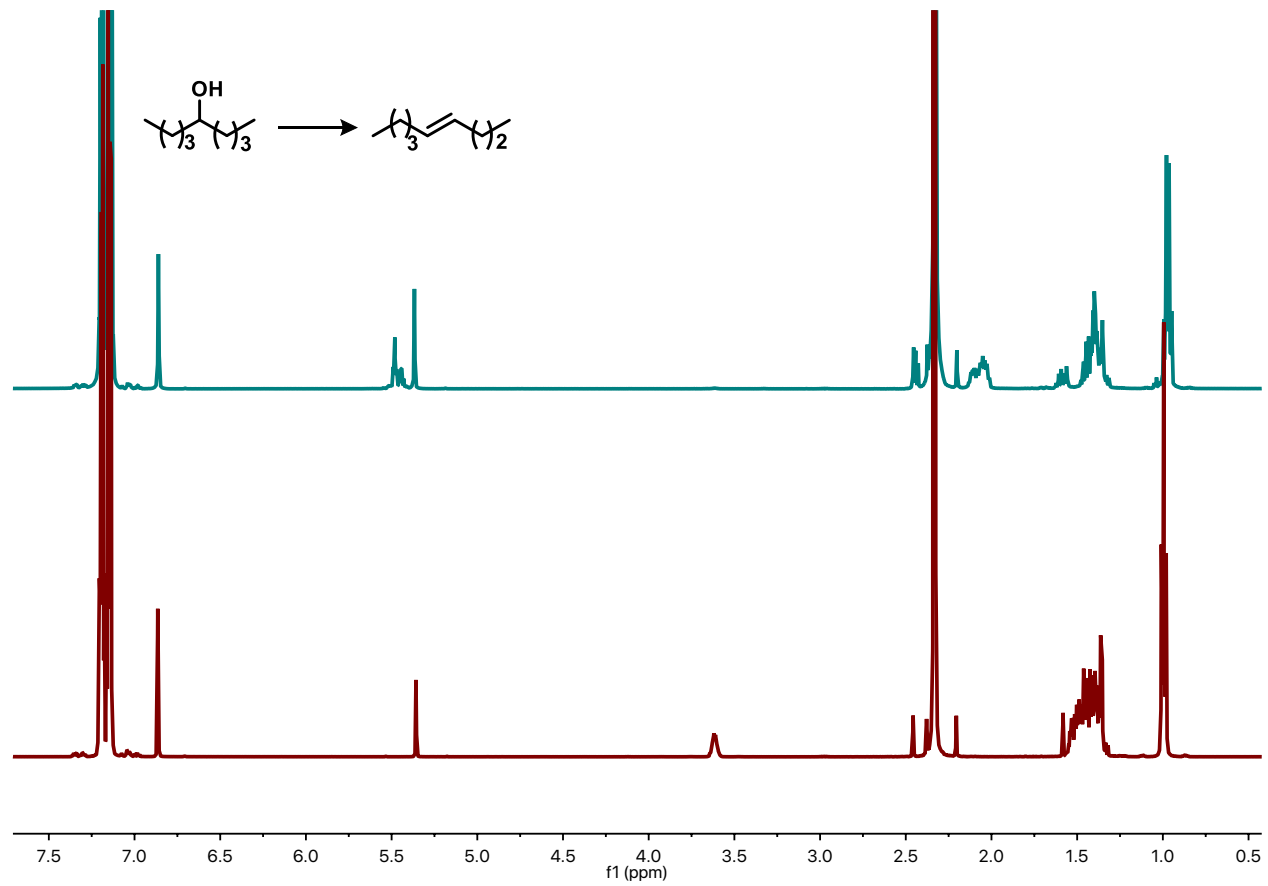

Figure S26. ${ }^{1} \mathrm{H}$ NMR $\left(500 \mathrm{MHz}\right.$ in DCM- $\mathrm{d}_{2}$ ) before (red) and after (turquoise) the conversion of 5-nonanol (Table 1, Entry 13). 

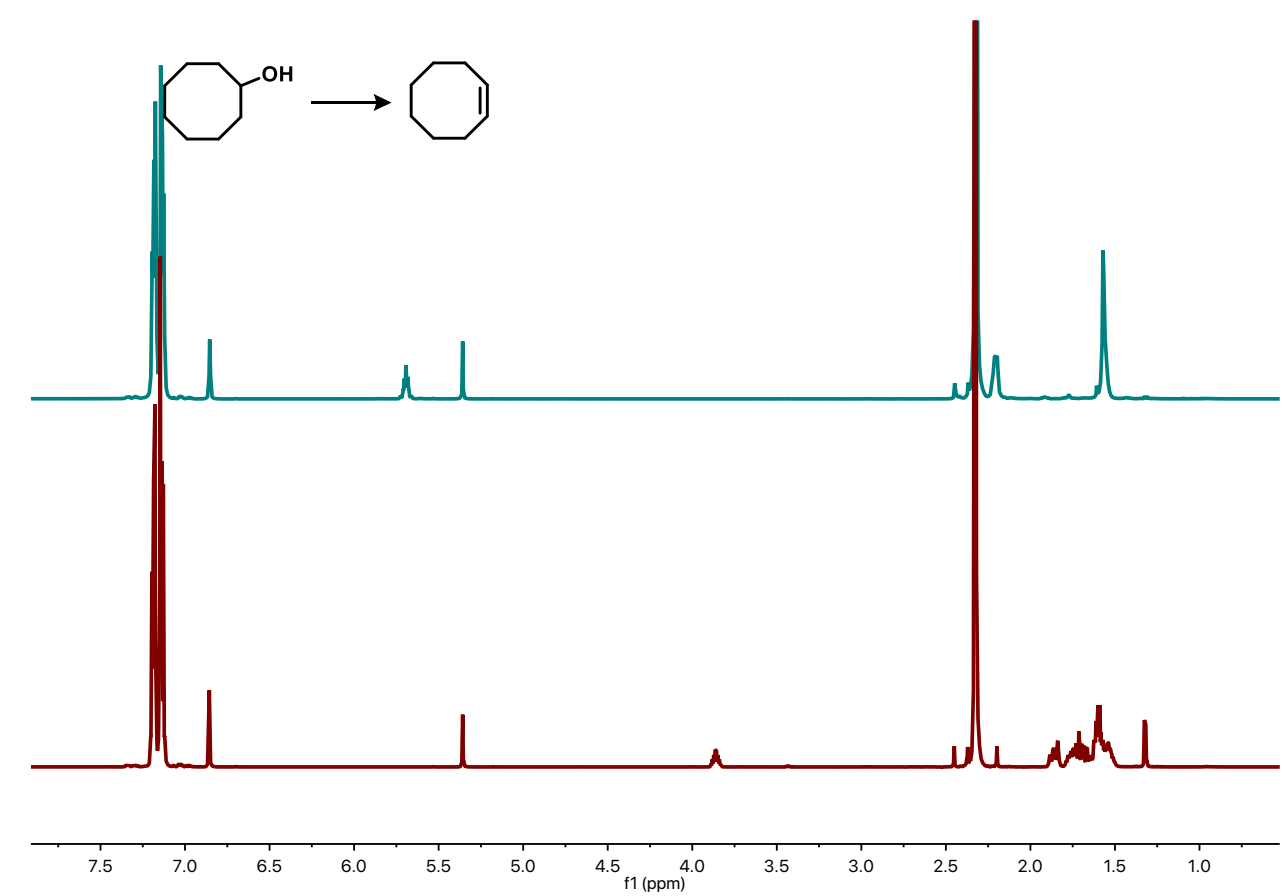

Figure S27. ${ }^{1} \mathrm{H}$ NMR (500 MHz in DCM- $\mathrm{d}_{2}$ ) before (red) and after (turquoise) the conversion of cyclo-octanol (Table 1, Entry 14).

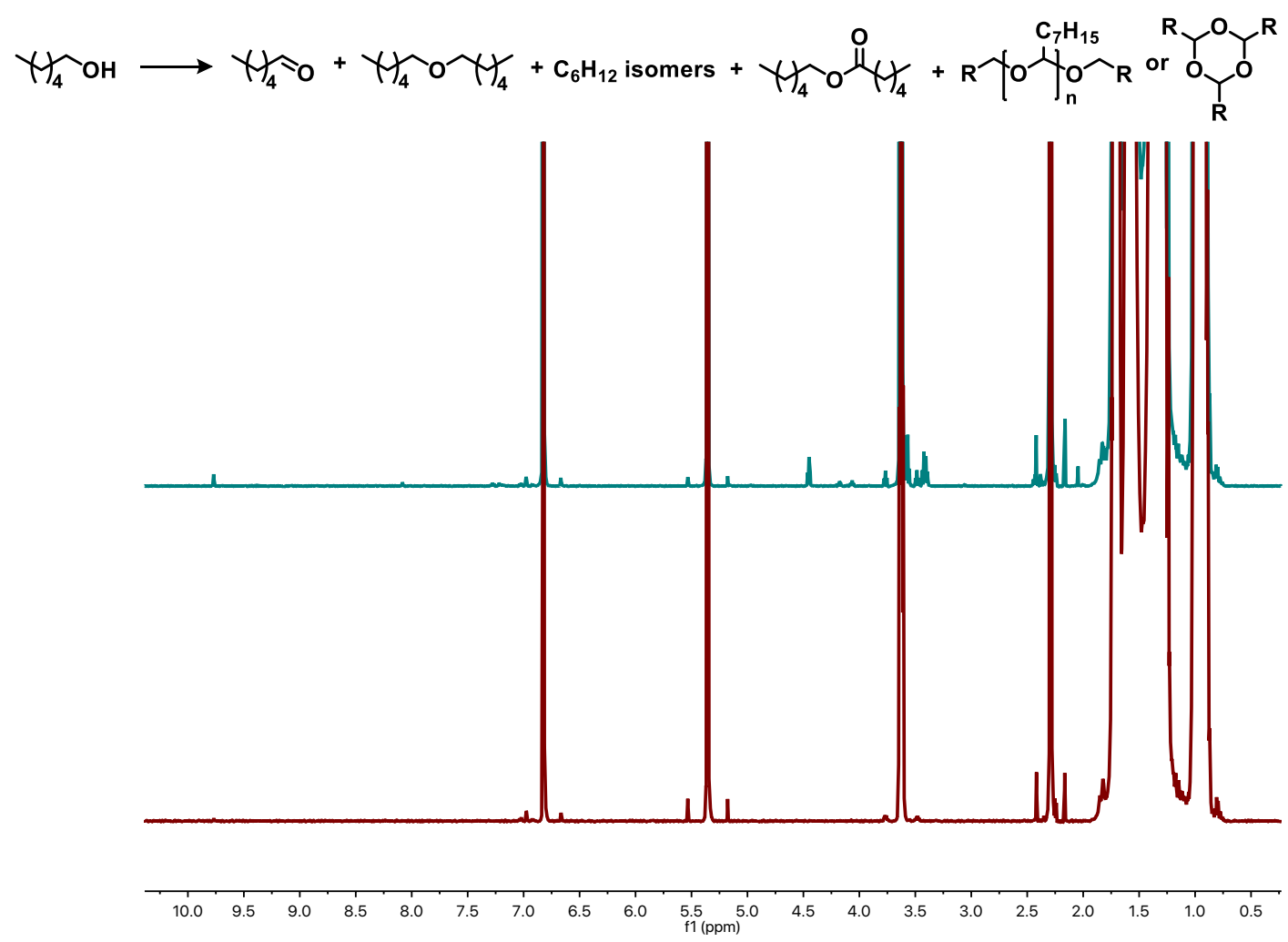

Figure S28. ${ }^{1} \mathrm{H}$ NMR (500 MHz in DCM- $\mathrm{d}_{2}$ ) before (red) and after (turquoise) the conversion of 1-hexanol (Table 1, Entry 15). 


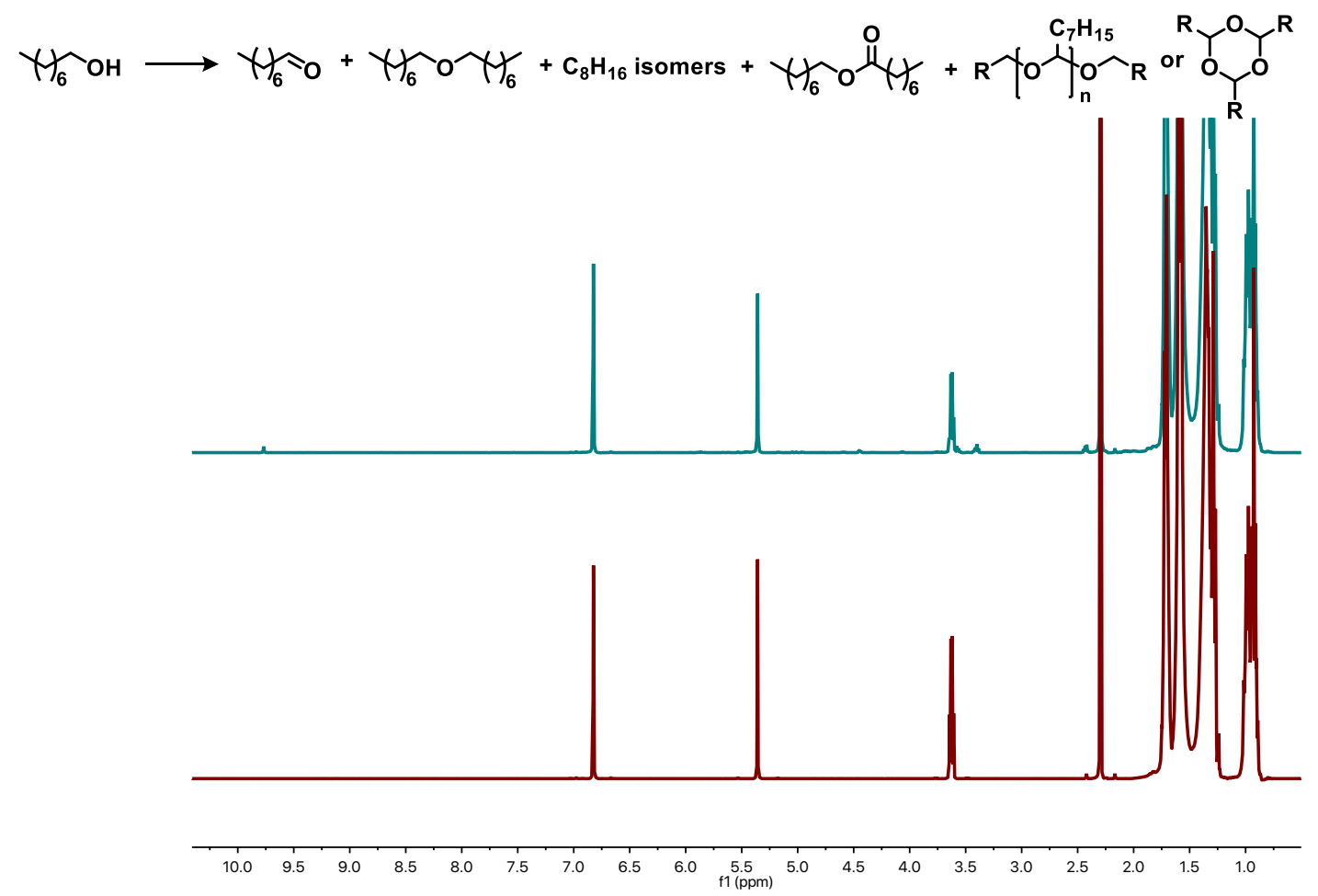

Figure S29. ${ }^{1} \mathrm{H}$ NMR $\left(500 \mathrm{MHz}\right.$ in $\left.\mathrm{DCM}-\mathrm{d}_{2}\right)$ before (red) and after (turquoise) the conversion of 1-octanol (Table 3, Entry 17).

Spectroscopic Data for Dehydrated/Dehydrogenated Products and References.<smiles>C=C(c1ccccc1)c1ccccc1</smiles>

1,1-diphenylethylene (Table 1 , entry 1$)^{33}$

${ }^{1} \mathrm{H}$ NMR spectrum has been previously reported.

${ }^{1} \mathrm{H} \mathrm{NMR}\left(\mathrm{CDCl}_{3}\right) \delta \mathrm{ppm} 7.31(10 \mathrm{H}), 5.44(2 \mathrm{H})$<smiles>C=C(C)c1ccccc1</smiles>

isopropenylbenzene (Table 1 , entry 3$)^{34}$

${ }^{1} \mathrm{H}$ NMR spectrum has been previously reported.

${ }^{1} \mathrm{H}$ NMR $\left(\mathrm{CDCl}_{3}\right) \delta \mathrm{ppm}$ 7.55-7.17 (m, 5H), $5.35(1 \mathrm{H}), 5.06(1 \mathrm{H}), 2.13(3 \mathrm{H})$<smiles>CC=C(CC)CC</smiles>

3-ethyl-2-pentene (Table 1, entry 5$)^{35}$

${ }^{1} \mathrm{H}$ NMR spectrum has been previously reported.

${ }^{1} \mathrm{H}$ NMR $\left(\mathrm{CDCl}_{3}\right) \delta$ ppm $5.15(1 \mathrm{H}), 1.99-2.03(4 \mathrm{H}), 1.57(3 \mathrm{H}), 0.97-0.95(6 \mathrm{H})$ 
事

Ocimene (Table 1 , entry 8$)^{36}$

${ }^{1} \mathrm{H}$ NMR spectrum has been previously reported.

${ }^{1} \mathrm{H} \mathrm{NMR}\left(\mathrm{CDCl}_{3}\right) \delta \mathrm{ppm} 5.4(1 \mathrm{H}), 4.7(2 \mathrm{H}), 1.75(3 \mathrm{H}), 1.67(3 \mathrm{H})$<smiles>C=CC(=C)CCC=C(C)C</smiles>

Myrcene (Table 1, entry 8) 36

${ }^{1} \mathrm{H}$ NMR spectrum has been previously reported.

${ }^{1} \mathrm{H} \mathrm{NMR}\left(\mathrm{CDCl}_{3}\right) \delta \mathrm{ppm} 6.38(1 \mathrm{H})$<smiles>C=C(C)C1CCC(C)CC1</smiles>

Limonene (Table 1, entry 9$)^{36}$

${ }^{1} \mathrm{H}$ NMR spectrum has been previously reported.

${ }^{1} \mathrm{H} \mathrm{NMR}\left(\mathrm{CDCl}_{3}\right) \delta$ ppm $5.42(1 \mathrm{H}), 4.70(2 \mathrm{H}), 1.75(3 \mathrm{H}), 1.67(3 \mathrm{H})$<smiles>Cc1ccc(C(C)C)cc1</smiles>

Alpha-terpinene (Table 1, entry 9) ${ }^{37}$

${ }^{1} \mathrm{H}$ NMR spectrum has been previously reported.

${ }^{1} \mathrm{H} \mathrm{NMR}\left(\mathrm{CDCl}_{3}\right) \delta \mathrm{ppm} 5.62(1 \mathrm{H}), 5.59(1 \mathrm{H}), 2.28(1 \mathrm{H}), 2.09(4 \mathrm{H}), 1.77(3 \mathrm{H}), 1.02(6 \mathrm{H})$

${ }^{13} \mathrm{C} \mathrm{NMR}\left(\mathrm{CDCl}_{3}\right) \delta \mathrm{ppm} 142,133,120,117,35,29,25,23,21$<smiles>CC1=CCC(C(C)C)=CC1</smiles>

Gamma-terpinene (Table 1, entry 9) ${ }^{38}$

${ }^{1} \mathrm{H}$ NMR spectrum has been previously reported.

${ }^{1} \mathrm{H}$ NMR $\left(\mathrm{CDCl}_{3}\right) \delta$ ppm $5.43(2 \mathrm{H}), 2.6(4 \mathrm{H}), 2.2(1 \mathrm{H}), 1.66(3 \mathrm{H}), 1.0(6 \mathrm{H})$

${ }^{13} \mathrm{C} \mathrm{NMR}\left(\mathrm{CDCl}_{3}\right) \delta \mathrm{ppm} 140.6,131.3,118.9,116.1,34.6,31.7,27.6,23.0,21.3$<smiles>CC1=CCC(=C(C)C)CC1</smiles>

Theta-terpinene (Table 1, entry 9) ${ }^{39}$

${ }^{1} \mathrm{H}$ NMR spectrum has been previously reported.

${ }^{1} \mathrm{H}$ NMR $\left(\mathrm{CDCl}_{3}\right) \delta \mathrm{ppm} 5.40(1 \mathrm{H}), 2.76(2 \mathrm{H}), 2.36(2 \mathrm{H}), 2.05(2 \mathrm{H}), 1.71(3 \mathrm{H}), 1.70(3 \mathrm{H}), 1.68$ (3H) 
${ }^{13} \mathrm{C} \mathrm{NMR}\left(\mathrm{CDCl}_{3}\right) \delta \mathrm{ppm} 134.0,127.6,121.6,120.8,31.5,29.5,26.6,23.4,19.8,19.7$<smiles>CCc1ccc2ccccc2c1</smiles>

2-vinyl naphthalene (Table 1, entry 10$)^{40}$

${ }^{1} \mathrm{H}$ NMR spectrum has been previously reported.

${ }^{1} \mathrm{H} \mathrm{NMR}\left(\mathrm{CDCl}_{3}\right) \delta \mathrm{ppm}$ 7.79-7.77 (3H), $7.73(1 \mathrm{H}), 7.62(1 \mathrm{H}), 7.43(2 \mathrm{H}), 6.87(1 \mathrm{H}), 5.86(1 \mathrm{H})$, $5.32(1 \mathrm{H})$<smiles>CC=Cc1ccccc1</smiles>

1-phenylpropene (Table 1, entry 11$)^{35}$

${ }^{1} \mathrm{H}$ NMR spectrum has been previously reported.

${ }^{1} \mathrm{H} \mathrm{NMR}\left(\mathrm{CDCl}_{3}\right) \delta \mathrm{ppm}$ 7.37-7.2 (5H), 6.45-6.40 (1H), 6.31-6.26 (1H), 1.92-1.89 (3H)<smiles>C=Cc1ccccc1</smiles>

Styrene (Table 1 , entry 12$)^{3}$

${ }^{1} \mathrm{H}$ NMR spectrum has been previously reported.

${ }^{1} \mathrm{H} \mathrm{NMR}\left(\mathrm{CDCl}_{3}\right) \delta \mathrm{ppm} 7.50-7.10(5 \mathrm{H}), 6.69(1 \mathrm{H}), 5.74(1 \mathrm{H}), 5.25(1 \mathrm{H})$<smiles>CC(=O)c1ccccc1</smiles>

Acetophenone (Table 1, entry 12$)^{4}$

${ }^{1} \mathrm{H}$ NMR spectrum has been previously reported.

${ }^{1} \mathrm{H} \mathrm{NMR}\left(\mathrm{CDCl}_{3}\right) \delta \mathrm{ppm} 7.94(2 \mathrm{H}), 7.68-7.32(3 \mathrm{H}), 2.58(3 \mathrm{H})$<smiles>CC(c1ccccc1)c1ccccc1C(C)c1ccccc1</smiles>

Bis(alpha-methylbenzyl) ether (Table 1, entry 12$)^{5}$

${ }^{1} \mathrm{H}$ NMR spectrum has been previously reported (optical isomers).

${ }^{1} \mathrm{H} \mathrm{NMR}\left(\mathrm{CDCl}_{3}\right) \delta$ ppm 7.34-7.20 (10H), 4.52-4.24 (2H), 1.45-1.38 (6H)<smiles>CC(C=CC1=CC=CC1)C1C=CC=C1</smiles>

(E)-But-1-ene-1,3-diyldibenzene (Table 1, entry 12)

${ }^{1} \mathrm{H}$ NMR spectrum has been previously reported.

${ }^{1} \mathrm{H}$ NMR $\left(\mathrm{CDCl}_{3}\right) \delta \mathrm{ppm}$ 7.29-7.09 (10H), 6.36-6.27 (2H), 3.64-3.53 (1H), $1.39(3 \mathrm{H})$

${ }^{13} \mathrm{C} \mathrm{NMR}\left(\mathrm{CDCl}_{3}\right) \delta \mathrm{ppm} 144.6,136.5,134.2,127.4,126.3,126.0,125.2,125.1,41.5,20.2$

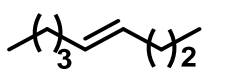

4- nonene (Table 1 , entry 13$)^{41}$

${ }^{1} \mathrm{H}$ NMR spectrum has been previously reported. 
${ }^{1} \mathrm{H}$ NMR $\left(\mathrm{CDCl}_{3}\right) \delta$ ppm $5.39(2 \mathrm{H}), 1.98(4 \mathrm{H}), 1.36-1.32(8 \mathrm{H}), 0.88(6 \mathrm{H})$<smiles>C1=CCCCC1</smiles>

Cyclooctene (Table 1 , entry 14$)^{42}$

${ }^{1} \mathrm{H}$ NMR spectrum has been previously reported.

${ }^{1} \mathrm{H} \mathrm{NMR}\left(\mathrm{CDCl}_{3}\right) \delta$ ppm $5.61(2 \mathrm{H}), 2.14(4 \mathrm{H}), 1.49(8 \mathrm{H})$

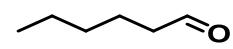

Hexanal (Table 1, entry 15)

${ }^{1} \mathrm{H}$ NMR spectrum has been previously reported.

${ }^{1} \mathrm{H} \mathrm{NMR}\left(\mathrm{CDCl}_{3}\right) \delta \mathrm{ppm} 9.8(1 \mathrm{H}), 2.4(2 \mathrm{H}), 1.6(2 \mathrm{H}), 1.3(4 \mathrm{H}), 0.9(3 \mathrm{H})$

$\overbrace{0}$

Octanal (Table 1 , entry 17$)^{13}$

${ }^{1} \mathrm{H}$ NMR spectrum has been previously reported.

${ }^{1} \mathrm{H} \mathrm{NMR}\left(\mathrm{CDCl}_{3}\right) \delta \mathrm{ppm} 9.76(1 \mathrm{H}), 2.41(2 \mathrm{H}), 1.63(2 \mathrm{H}), 1.3(8 \mathrm{H}), 0.88(3 \mathrm{H})$

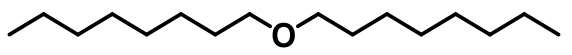

Dioctyl ether (Table 1, entry 17$)^{20}$

${ }^{1} \mathrm{H}$ NMR spectrum has been previously reported.

${ }^{1} \mathrm{H} \mathrm{NMR}\left(\mathrm{CDCl}_{3}\right) \delta \mathrm{ppm} 3.38(4 \mathrm{H}), 1.56(4 \mathrm{H}), 1.28(24 \mathrm{H}), 0.89(6 \mathrm{H})$

${ }^{13} \mathrm{C} \mathrm{NMR}\left(\mathrm{CDCl}_{3}\right) \delta \mathrm{ppm} 71.0,31.9,29.9,29.6,29.4,26.4,22.8,14.1$<smiles>CCCCCCCOC(=O)CCCCCCC</smiles>

Octyl octanoate (Table 1 , entry 17$)^{21}$

${ }^{1} \mathrm{H}$ NMR spectrum has been previously reported.

${ }^{1} \mathrm{H}$ NMR $\left(\mathrm{CDCl}_{3}\right) \delta \mathrm{ppm} 3.98(2 \mathrm{H}), 2.22(2 \mathrm{H}), 1.62-1.47(4 \mathrm{H}), 1.34-1.10(18 \mathrm{H}), 0.89-0.73(6 \mathrm{H})$

${ }^{13} \mathrm{C} \mathrm{NMR}\left(\mathrm{CDCl}_{3}\right) \delta \mathrm{ppm} 174,64,34,32,29,26,22,14$<smiles>CC1OC(C)C(C)O1</smiles>

2,4,6-trimethyl-1,3,5-trioxane (Table 1, entry 17) ${ }^{19}$

${ }^{1} \mathrm{H}$ NMR spectrum has been previously reported.

${ }^{1} \mathrm{H} \mathrm{NMR}\left(\mathrm{CDCl}_{3}\right) \delta$ ppm $4.9(3 \mathrm{H}), 1.3(9 \mathrm{H})$

${ }^{13} \mathrm{C} \mathrm{NMR}\left(\mathrm{CDCl}_{3}\right) \delta \mathrm{ppm} 98.7,20.8$

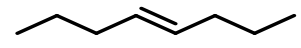

Trans-4-octene (Table 1, entry 17$)^{14}$

${ }^{1} \mathrm{H}$ NMR spectrum has been previously reported. 
${ }^{1} \mathrm{H} \mathrm{NMR}\left(\mathrm{CDCl}_{3}\right) \delta$ ppm $5.39(2 \mathrm{H}), 1.96(4 \mathrm{H}), 1.36(4 \mathrm{H}), 0.89(6 \mathrm{H})$

${ }^{13} \mathrm{C} \mathrm{NMR}\left(\mathrm{CDCl}_{3}\right) \delta \mathrm{ppm} 130.5,34.9,22.9,13.7$

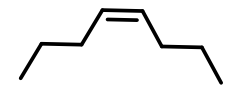

Cis-4-octene (Table 1 , entry 17$)^{15}$

${ }^{1} \mathrm{H}$ NMR spectrum has been previously reported.

${ }^{1} \mathrm{H} \mathrm{NMR}\left(\mathrm{CDCl}_{3}\right) \delta \mathrm{ppm} 5.4(2 \mathrm{H}), 2.0(4 \mathrm{H}), 1.4(4 \mathrm{H}), 0.9(6 \mathrm{H})$

${ }^{13} \mathrm{C} \mathrm{NMR}\left(\mathrm{CDCl}_{3}\right) \delta \mathrm{ppm} 129.9,29.5,23.0,13.8$

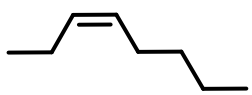

Cis-3-octene (Table 1 , entry 17$)^{16}$

${ }^{1} \mathrm{H}$ NMR spectrum has been previously reported.

${ }^{1} \mathrm{H} \mathrm{NMR}\left(\mathrm{CDCl}_{3}\right) \delta$ ppm $5.35(2 \mathrm{H}), 2.0(4 \mathrm{H}), 1.3(4 \mathrm{H}), 0.9(6 \mathrm{H})$

${ }^{13} \mathrm{C} \mathrm{NMR}\left(\mathrm{CDCl}_{3}\right) \delta \mathrm{ppm} 131.6,129.4,32.2,27.0,22.5,20.7,14.5,14.0$

حrans-2-octene

Trans-2-octene (Table 1, entry 17$)^{17}$

${ }^{1} \mathrm{H}$ NMR spectrum has been previously reported.

${ }^{1} \mathrm{H}$ NMR $\left(\mathrm{CDCl}_{3}\right) \delta$ ppm 5.5-5.3 (2H), $1.9(2 \mathrm{H}), 1.6(1 \mathrm{H}), 1.5-1.0(6 \mathrm{H}), 0.9(3 \mathrm{H})$

${ }^{13} \mathrm{C} \mathrm{NMR}\left(\mathrm{CDCl}_{3}\right) \delta \mathrm{ppm} 131.0,123.7,31.8,29.5,27.0,22.8,14.1,12.7$

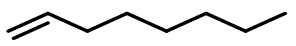

1-octene (Table 1 , entry 17$)^{18}$

${ }^{1} \mathrm{H}$ NMR spectrum has been previously reported.

${ }^{1} \mathrm{H}$ NMR $\left(\mathrm{CDCl}_{3}\right) \delta$ ppm $5.8(1 \mathrm{H}), 5.0-4.9(2 \mathrm{H}), 2.0(2 \mathrm{H}), 1.5-1.0(8 \mathrm{H}), 0.9(3 \mathrm{H})$

${ }^{13} \mathrm{C} \mathrm{NMR}\left(\mathrm{CDCl}_{3}\right) \delta \mathrm{ppm} 139.2,114.1,33.9,31.9,29.1,29.0,22.7,14.1$

\section{References}

1. Mouat, A. R.; Lohr, T. L.; Wegener, E. C.; Miller, J. T.; Delferro, M.; Stair, P. C.; Marks, T. J., Reactivity of a Carbon-Supported Single-Site Molybdenum Dioxo Catalyst for Biodiesel Synthesis. ACS Catal. 2016, 6 (10), 6762-6769.

2. Korstanje, T. J.; de Waard, E. F.; Jastrzebski, J. T. B. H.; Klein Gebbink, R. J. M., RheniumCatalyzed Dehydration of Nonbenzylic and Terpene Alcohols to Olefins. ACS Catal. 2012, 2 (10), 21732181.

3. Spectral Database for Organic Compounds (SDBS) H-NMR spectrum, S. N. H.---., SDBSWeb: https://sdbs.db.aist.go.jp (National Institute of Advanced Industrial Science and Technology, October 28th 2020).

4. Spectral Database for Organic Compounds (SDBS) H-NMR spectrum, SDBS No. 722HSP-00-828, SDBSWeb: https://sdbs.db.aist.go.jp (National Institute of Advanced Industrial Science and Technology, October 28th 2020).

5. Spectral Database for Organic Compounds (SDBS) H-NMR spectrum, SDBS No. 93-96-9, SDBSWeb: https://sdbs.db.aist.go.jp (National Institute of Advanced Industrial Science and Technology, October 28th 2020). 
6. Han, F.; Yang, L.; Li, Z.; Zhao, Y.; Xia, C., Metal-Free and Recyclable Route to Synthesize Polysubstituted Olefins via C-C Bond Construction from Direct Dehydrative Coupling of Alcohols or Alkenes with Alcohols Catalyzed by Sulfonic Acid-Functionalized Ionic Liquids. Adv. Synth. Catal. 2014, 356 (11-12), 2506-2516.

7. $\quad$ Chevella, D.; Macharla, A. K.; Kodumuri, S.; Banothu, R.; Gajula, K. S.; Amrutham, V.; Gennadievna, G. e. N.; Nama, N., Synthesis of internal olefins by direct coupling of alcohols and olefins over Moß zeolite. Catal. Commun. 2019, 123, 114-118.

8. Tarlani, A.; Riahi, A.; Abedini, M.; Amini, M. M.; Muzart, J., Wells-Dawson tungsten heteropolyacid-catalyzed reactions of benzylic alcohols, influence of the structure of the substrate. J. Mol. Catal. A: Chem. 2006, 260 (1), 187-189.

9. Tsukada, N.; Sato, T.; Inoue, Y., Palladium-catalyzed allylic alkenylation of allylic alcohols with nbutyl acrylate. Chem. Commun. 2003, (19), 2404-2405.

10. Christiansen, M. A.; Mpourmpakis, G.; Vlachos, D. G., Density Functional Theory-Computed Mechanisms of Ethylene and Diethyl Ether Formation from Ethanol on $\gamma$-Al2O3(100). ACS Catal. 2013, 3 (9), 1965-1975.

11. Kumar, V. G.; Rao, M. R.; Ravindran, P. V.; Rao, K. V. C., Oligomerization of styrene over molybdenum oxide on silica-alumina catalyst. J. Polym. Sci., Polym. Chem. Ed. 1983, 21 (7), 2133-2144.

12. Matyjaszewski, K., Carbocationic Polymerization: Styrene and Substituted Styrenes. In Comprehensive Polymer Science and Supplements, Allen, G.; Bevington, J. C., Eds. Pergamon: Amsterdam, 1989; pp 639-671.

13. Spectral Database for Organic Compounds (SDBS) H-NMR spectrum, SDBS No. 4269HSP-02-548, SDBSWeb: https://sdbs.db.aist.go.jp (National Institute of Advanced Industrial Science and Technology, October 28th 2020).

14. Spectral Database for Organic Compounds (SDBS) H-NMR spectrum, SDBS No. 278CDS-00-026, SDBSWeb: https://sdbs.db.aist.go.jp (National Institute of Advanced Industrial Science and Technology, October 28th 2020).

15. Spectral Database for Organic Compounds (SDBS) H-NMR spectrum, SDBS No. 277HSP-03-378, SDBSWeb: https://sdbs.db.aist.go.jp (National Institute of Advanced Industrial Science and Technology, October 28th 2020).

16. Spectral Database for Organic Compounds (SDBS) H-NMR spectrum, SDBS No. 279HSP-03-385, SDBSWeb: https://sdbs.db.aist.go.jp (National Institute of Advanced Industrial Science and Technology, October 28th 2020).

17. Spectral Database for Organic Compounds (SDBS) H-NMR spectrum, SDBS No. 281HSP-03-379, SDBSWeb: https://sdbs.db.aist.go.jp (National Institute of Advanced Industrial Science and Technology, October 28th 2020).

18. Spectral Database for Organic Compounds (SDBS) H-NMR spectrum, SDBS No. 788HSP-00-085, SDBSWeb: https://sdbs.db.aist.go.jp (National Institute of Advanced Industrial Science and Technology, October 28th 2020).

19. Spectral Database for Organic Compounds (SDBS) H-NMR spectrum, SDBS No. 123-63-7, SDBSWeb: https://sdbs.db.aist.go.jp (National Institute of Advanced Industrial Science and Technology, October 28th 2020).

20. Spectral Database for Organic Compounds (SDBS) H-NMR spectrum, SDBS No. 7770HSP-02-236, SDBSWeb: https://sdbs.db.aist.go.jp (National Institute of Advanced Industrial Science and Technology, October 28th 2020).

21. Gowrisankar, S.; Neumann, H.; Beller, M., General and Selective Palladium-Catalyzed Oxidative Esterification of Alcohols. Angew. Chem. Int. Ed. 2011, 50 (22), 5139-5143.

22. Gunanathan, C.; Shimon, L. J. W.; Milstein, D., Direct Conversion of Alcohols to Acetals and H2 Catalyzed by an Acridine-Based Ruthenium Pincer Complex. J. Am. Chem. Soc. 2009, 131 (9), 3146-3147. 
23. Miura, H.; Nakahara, K.; Kitajima, T.; Shishido, T., Concerted Functions of Surface Acid-Base Pairs and Supported Copper Catalysts for Dehydrogenative Synthesis of Esters from Primary Alcohols. ACS Omega 2017, 2 (9), 6167-6173.

24. Spasyuk, D.; Smith, S.; Gusev, D. G., From Esters to Alcohols and Back with Ruthenium and Osmium Catalysts. Angew. Chem. Int. Ed. 2012, 51 (11), 2772-2775.

25. McCullough, L. R.; Childers, D. J.; Watson, R. A.; Kilos, B. A.; Barton, D. G.; Weitz, E.; Kung, H. H.; Notestein, J. M., Acceptorless Dehydrogenative Coupling of Neat Alcohols Using Group VI Sulfide Catalysts. ACS Sustain. Chem. Eng. 2017, 5 (6), 4890-4896.

26. Lohr, T. L.; Mouat, A. R.; Schweitzer, N. M.; Stair, P. C.; Delferro, M.; Marks, T. J., Efficient catalytic greenhouse gas-free hydrogen and aldehyde formation from aqueous alcohol solutions. Energy Environ. Sci. 2017, 10 (7), 1558-1562.

27. Neese, F., The ORCA program system. WIREs Comput. Mol. Sci. 2012, 2 (1), 73-78.

28. Bryantsev, V. S.; Diallo, M. S.; Goddard lii, W. A., Calculation of Solvation Free Energies of Charged Solutes Using Mixed Cluster/Continuum Models. J. Phys. Chem. B 2008, 112 (32), 9709-9719.

29. For $\mathrm{B}-\mathrm{H}$ migration, there are two possible oxygen moieties, hydroxy group and oxo group.

According to the calculated Gibbs free energy, interacting with $\mathrm{Mo}-\mathrm{OH}$ fragment is $7.6 \mathrm{kcal} / \mathrm{mol}$ lower in energy thus is the preferred pathway.

30. Li, Z.; Fang, Z.; Kelley, M. S.; Kay, B. D.; Rousseau, R.; Dohnalek, Z.; Dixon, D. A., Ethanol Conversion on Cyclic (MO3)3 (M = Mo, W) Clusters. J. Phys. Chem. C 2014, 118 (9), 4869-4877.

31. Rousseau, R.; Dixon, D. A.; Kay, B. D.; Dohnálek, Z., Dehydration, dehydrogenation, and condensation of alcohols on supported oxide catalysts based on cyclic (WO3)3 and (MoO3) 3 clusters. Chem. Soc. Rev. 2014, 43 (22), 7664-7680.

32. Kim, Y. K.; Rousseau, R.; Kay, B. D.; White, J. M.; Dohnálek, Z., Catalytic Dehydration of 2Propanol on (WO3)3 Clusters on TiO2(110). J. Am. Chem. Soc. 2008, 130 (15), 5059-5061.

33. Spectral Database for Organic Compounds (SDBS) H-NMR spectrum, SDBS No. 1821HSP-02-076, SDBSWeb: https://sdbs.db.aist.go.jp (National Institute of Advanced Industrial Science and Technology, October 28th 2020).

34. Spectral Database for Organic Compounds (SDBS) H-NMR spectrum, SDBS No. 2368HSP-00-055, SDBSWeb: https://sdbs.db.aist.go.jp (National Institute of Advanced Industrial Science and Technology, October 28th 2020).

35. Keskiväli, J.; Parviainen, A.; Lagerblom, K.; Repo, T., Transition metal triflate catalyzed conversion of alcohols, ethers and esters to olefins. RSC Advances 2018, 8 (27), 15111-15118.

36. Guerrini, A.; Sacchetti, G.; Muzzoli, M.; Moreno Rueda, G.; Medici, A.; Besco, E.; Bruni, R., Composition of the Volatile Fraction of Ocotea bofo Kunth (Lauraceae) Calyces by GC-MS and NMR Fingerprinting and Its Antimicrobial and Antioxidant Activity. J. Agric. Food. Chem. 2006, 54 (20), 77787788.

37. Spectral Database for Organic Compounds (SDBS) H-NMR spectrum, SDBS No.21425HSP-49-493, SDBSWeb: https://sdbs.db.aist.go.jp (National Institute of Advanced Industrial Science and Technology, October 28th 2020).

38. Spectral Database for Organic Compounds (SDBS) H-NMR spectrum, SDBS No.23242HSP-06-383, SDBSWeb: https://sdbs.db.aist.go.jp (National Institute of Advanced Industrial Science and Technology, October 28th 2020).

39. Zou, Y.; Wang, Q.; Goeke, A., Organocatalytic Multicomponent $\alpha$-Methylenation/Diels-Alder Reactions: A Versatile Route to Substituted Cyclohexenecarbaldehyde Derivatives. Chem. Eur. J. 2008, 14 (17), 5335-5345.

40. Spectral Database for Organic Compounds (SDBS) H-NMR spectrum, SDBS No. 827-54-3, SDBSWeb: https://sdbs.db.aist.go.jp (National Institute of Advanced Industrial Science and Technology, October 28th 2020). 
41. Spectral Database for Organic Compounds (SDBS) H-NMR spectrum, SDBS No. 2198-23-4, SDBSWeb: https://sdbs.db.aist.go.jp (National Institute of Advanced Industrial Science and Technology, October 28th 2020).

42. Spectral Database for Organic Compounds (SDBS) H-NMR spectrum, SDBS No. 2051HSP-03-574, SDBSWeb: https://sdbs.db.aist.go.jp (National Institute of Advanced Industrial Science and Technology, October 28th 2020). 